\title{
29. LATE NEOGENE AND QUATERNARY COARSE-FRACTION AND CARBONATE STRATIGRAPHIES FOR SITE 586 ON ONTONG-JAVA PLATEAU AND SITE 591 ON LORD HOWE RISE 1
}

\author{
James V. Gardner, Walter E. Dean, Lynne Bisagno, and Eileen Hemphill, U.S. Geological Survey²
}

\begin{abstract}
Carbonate oozes recovered by hydraulic piston coring at DSDP Site 586 on Ontong-Java Plateau and Site 591 on Lord Howe Rise have carbonate contents that are consistently higher than $90 \%$ with only minor variations. Consequently, paleoceanographic signals were not recorded in detail in the carbonate contents. However, mass accumulation rates of carbonate increased in the late Miocene to mid-Pliocene, reflecting an increase in productivity, then abruptly decreased from mid-Pliocene to the present. Variations in relative abundances of coarse material (foraminifers) and fine material (mostly calcareous nannofossils) do reflect histories of current winnowing and biogenic productivity at the two sites. The late Miocene from 10.5 to $6.5 \mathrm{~m}$.y. ago was a time of relatively constant, quiet, pelagic sedimentation with typical southwest Pacific sedimentation rates of $20-25 \mathrm{~m} / \mathrm{m}$. y. The average coarse-fraction abundances are always higher at Site 586 than at Site 591, which reflects winnowing at Site 586. These conditions were interrupted between 6.5 to $4.0 \mathrm{~m} . \mathrm{y}$. ago when increased upwelling at the Subtropical Divergence and the Equatorial Divergence produced greater productivity of calcareous planktonic organisms. The increased productivity is suggested by large increases in both fineand coarse-fraction material and constant ratios of foraminifers to nannofossils. The maximum of productivity was about $4.0 \mathrm{~m}$.y. ago. This period of increased upwelling is coincident with the inferred development of the West Antarctic ice sheet. The high productivity was followed by an abrupt increase in winnowing about $2.5 \mathrm{~m}$.y. ago at Site 591 , but not until about 2.0 m.y. ago at Site 586. By 2.0 m.y. ago in the late Pliocene, quiet, pelagic sedimentation conditions prevailed, similar to those of the late Miocene. The last $0.7 \mathrm{~m} . \mathrm{y}$. has been a period of relatively intense winnowing on Lord Howe Rise but not on Ontong-Java Plateau.

The coarse-fraction data have both long- and short-period fluctuations. Long-period fluctuations at Site 591 average about $850 \times 10^{3} \mathrm{yr}$./cycle and those at Site 586 average $430 \times 10^{3} \mathrm{yr}$. $/$ cycle. The highest amplitudes are found in the Pliocene and Quaternary sections. The short-period fluctuations range from 100 to $48 \times 10^{3} \mathrm{yr}$./cycle at Site 586 and from 250 to $33 \times 10^{3} \mathrm{yr}$./cycle at Site 591 . The effects of local fluctuations of productivity and winnowing have modified the primary orbital forcing signals at these two sites to yield complex paleoceanographic records.
\end{abstract}

\section{INTRODUCTION}

Shackleton and Opdyke (1976) published their classic study of the oxygen-isotope composition of late Pliocene and Quaternary planktonic foraminifers from piston Core V28-239 from Ontong-Java Plateau, and also presented a high-resolution (1 sample/5 $10^{3} \mathrm{yr}$.) stratigraphy of the percent coarse fraction $(>180 \mu \mathrm{m})$. The coarse-fraction record in Core V28-239 is strongly correlated with the oxygen-isotope record; the oxygen-isotope stages with higher values of $\delta^{18} \mathrm{O}$ (i.e., colder periods; Stages 2, 4, 6, etc.) have more coarse material than do those with lighter $\delta^{18} \mathrm{O}$ values. Because Core V28-239 was collected in a water depth of $3490 \mathrm{~m}$, below the foraminiferal lysocline, Shackleton and Opdyke (1976) assumed that the increases in coarse fraction were due to carbonate dissolution. Studies of carbonate dissolution on Ontong-Java Plateau place the top of the calcite lysocline at about $3400 \mathrm{~m}$ (Johnson et al., 1977; Berger et al., 1982); consequently, dissolution is likely to have occurred in Core V28-239. Shackleton and Opdyke (1976) did not discuss the details of the coarse-fraction data from Core V28-239, but focused on the significance of the oxygen-isotope data.

\footnotetext{
${ }^{1}$ Kennett, J. P., von der Borch, C. C., et al., Init. Repts, DSDP, 90: Washington (U.S. Govt, Printing Office)

Addresses: (Gardner, Bisagno, Hemphill) U.S. Geological Survey, Menlo Park, CA 94025; (Dean) U.S. Geological Survey, Denver, CO 80303
}

On Leg 90, during the splitting of the cores, the shipboard sedimentologists noticed that there appeared to be fluctuations of observable foraminiferal tests with depth, especially in sediment from Site 586 on Ontong-Java Plateau. This observation prompted us to sample Site 586 for coarse-fraction analyses and, for a comparison, we also chose to sample sediment from Site 591, adjacent to the Subtropical Divergence on Lord Howe Rise. We reasoned that fluctuations in the coarse fraction must be a response to (1) dissolution of carbonate, (2) winnowing of fine-grained material, or (3) deposition of finegrained material. All three of these processes are responses to oceanographic conditions; therefore, the coarsefraction stratigraphies should provide insights into late Neogene paleoceanographic changes that occurred in the southwest Pacific.

Site 586 is located within $2 \mathrm{~km}$ of DSDP Site 289 (Andrews, Packham, et al., 1975) in $2208 \mathrm{~m}$ of water on the eastern flank of Ontong-Java Plateau (Fig. 1). The hydraulic piston corer (HPC) was used to obtain $98 \%$ recovery of a virtually undisturbed 300 -m composite section. The sediment is foraminifer-nannofossil ooze to foraminifer-bearing nannofossil ooze, and the oldest sediment recovered is earliest late Miocene in age. The Quaternary section on Ontong-Java Plateau has been extensively studied, principally by Thompson and Saito (1974), Shackleton and Opdyke (1973; 1976), Berger and Johnson (1976), Berger et al. (1977; 1979), Thompson and Sciarrillo (1978), Krishnamurthy et al. (1979), Bonneau 


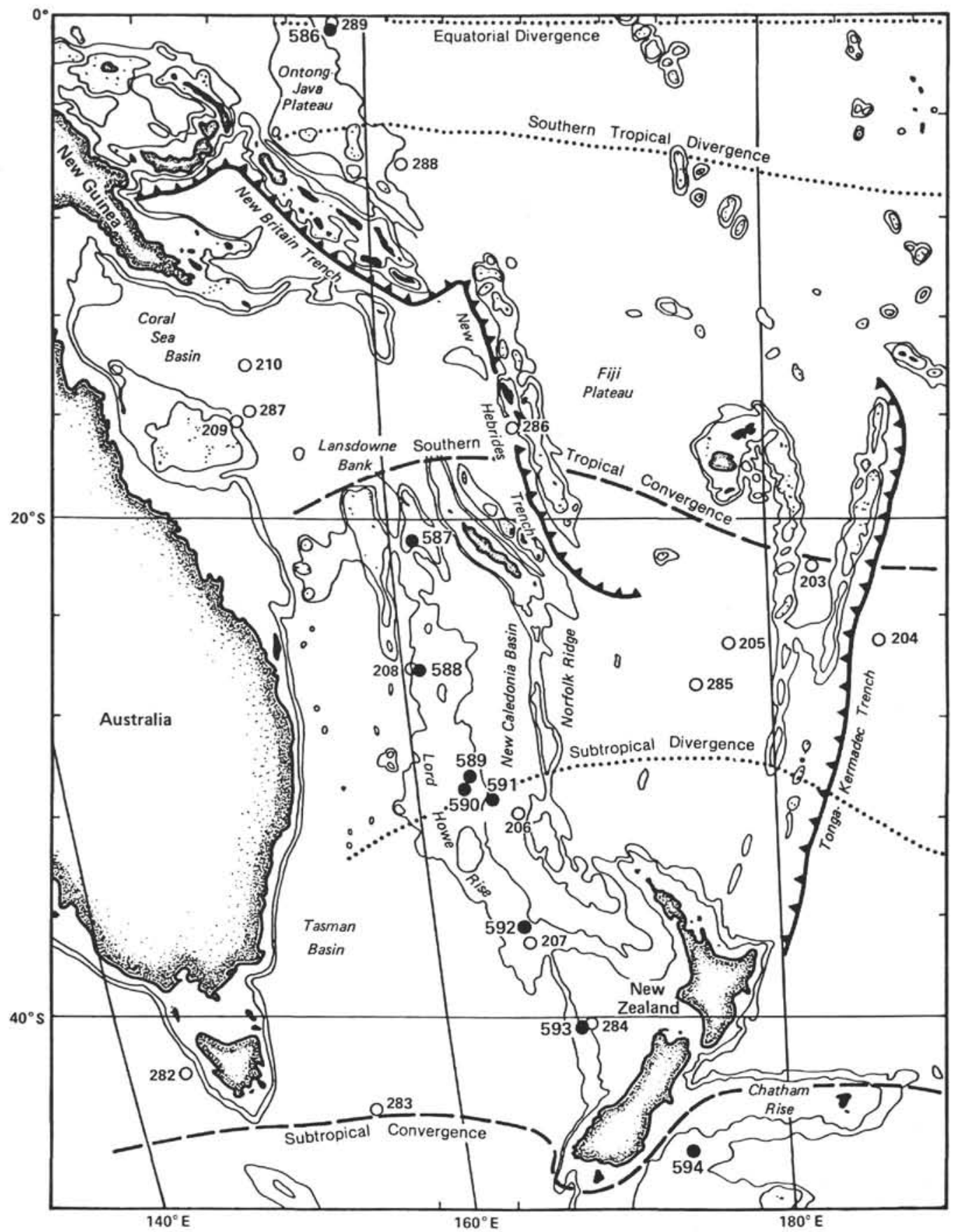

Figure 1. Map of the southwest Pacific Ocean showing the locations of DSDP Sites 206, 289, 586, and 591, and major water-mass boundaries.

et al. (1980), and Vincent et al. (1981). The rotarydrilled late Neogene section at Site 289 on Ontong-Java Plateau was investigated (Klein, 1975; van der Lingen and Packham, 1975; Holdsworth, 1975; Woodruff, et al., 1981), but those studies are based on widely separated samples of sediment that were severely disturbed by drilling.

Site 591 is located on the eastern flank of Lord Howe Rise in $2142 \mathrm{~m}$ of water (Fig. 1). The upper $284 \mathrm{~m}$ of the site was drilled with the HPC and recovered $98 \%$ section; below $284 \mathrm{~m}$ the section was drilled with the extended core barrel and averaged only $44 \%$ recovery. The undisturbed sediment is foraminifer-bearing nannofossil ooze that grades to chalk at about $300 \mathrm{~m}$ sub-bottom. The oldest sediment recovered is latest early Miocene in age.

\section{METHODS}

Samples for coarse-fraction analyses were collected approximately every $40 \mathrm{~cm}$ at Site 586 and every $50 \mathrm{~cm}$ at Site 591 . Average sedimentation rates, based on nannofossil biostratigraphy (Introduction, this volume), average about $27 \mathrm{~m} / \mathrm{m} . \mathrm{y}$. for Site 586 and about $32 \mathrm{~m} / \mathrm{m} . \mathrm{y}$. for Site 591. The sample spacing yields an approximate time series with an average of one sample every $15 \times 10^{3} \mathrm{yr}$. for Site 586 and one sample every $16 \times 10^{3} \mathrm{yr}$. for Site 591 . The highest frequency of cycles 
that may be defined from a periodic series is twice the sampling interval (Davis, 1973; also see Ledbetter and Ellwood, 1976). This highest frequency, called the Nyquist frequency, is therefore about $30 \times 10^{3} \mathrm{yr}$./ cycle for our time series from Sites 586 and 591 .

Samples were first split into three subsamples: one for calculation of a water-content correction factor so that it was not necessary to dry the coarse-fraction samples before they were disaggregated; a second split for coarse-fraction analysis; and a third, very small split for smearslide examination. Each correction-factor split was weighed, dried in an oven at $60^{\circ} \mathrm{C}$ for $24 \mathrm{hr}$., cooled in a desiccator, and weighed again. The correction factor was calculated using Equation 1:

$$
\text { CORR }=\frac{\mathrm{DWa}}{\mathrm{WWa}}
$$

where DWa is the dried weight of the sample and WWa is the initial wet weight of the sample. The correction factor was used to calculate the weight of dry sediment in the split used for coarse-fraction analysis using Equation 2:

$$
\mathrm{P}_{147}=\frac{\mathrm{W}_{147}}{\mathrm{WWb} \times \mathrm{CORR}} \times 100
$$

where $\mathrm{P}_{147}$ is the percentage of the sample $>147 \mu \mathrm{m}, \mathrm{W}_{147}$ is the weight of the $>147 \mu \mathrm{m}$ fraction, and WWb is the wet weight of the original coarse-fraction split. The same calculations were carried out on the fraction between 63 and $147 \mu \mathrm{m}$. The percentages of coarse fraction $(>63 \mu \mathrm{m})$ and fine fraction $(<63 \mu \mathrm{m})$ were calculated by difference from the analytical results.

Nearly all the carbonate data presented here were analyzed aboard ship using the carbonate bomb (Müller and Gastner, 1971). The shipboard data from both sites show step increases in carbonate with depth (Fig. 2A, B) that we suspect are calibration errors. Consequently, we reanalyzed some of the original bomb samples from the intervals that bridge the step increases using a coulometric carbon analyzer with a precision and accuracy that are both better than $\pm 1 \%$ (Huffman, 1977). To correct these errors, the upper sections were adjusted by adding the difference between the mean values of the reruns and the mean of the carbonate bomb analyses to each data point above the step change. The resulting adjusted curves (Fig. 2C, D) are considered to be more representative of the carbonate stratigraphy than are the original curves.

In order to investigate the timing of events in the coarse-fraction record and to calculate periodicities of the cycles, we had to apply an age model to each site. We used the nannofossil zonation and age boundaries established for Leg 90 (Introduction, this volume; Table 1) but with some apparent difficulties. A plot of age versus sedimentation rate for Site 591 (Fig. 3) shows that nannofossil Zones NN12 to NN15 have anomalously high sedimentation rates. When similar plots were constructed for all of the Leg 90 sites and for Site 586 (Fig. 3), the same nannofossil zones between 3.5 and $5.0 \mathrm{~m} . \mathrm{y}$. have very high sedimentation rates, often an order of magnitude greater than those for the other zones. It is possible that either the ages of the nannofossil zone boundaries, or the criteria for their recognition, or both, may be in error but we assumed that the biostratigraphy and ages are correct. We used the Leg 90 biostratigraphy (Introduction, this volume) for Site 591, but we had difficulties with the data from Site 586. We plotted several different age models for Site 586 using different biostratigraphic zonations and compared different sections of the record (Fig. 4). When the western North Pacific nannofossil zonation of Ellis (1981) is used, a severe compression of the data occurs in the interval from 1.8 to $2.1 \mathrm{~m} . y$., and an expansion of the data occurs in the interval from 0.9 to $1.8 \mathrm{~m}$.y. Similar compressions and expansions occur when the nannofossil zonation of Okada and Bukry (1980) or the planktonic foraminiferal zonation (Moberly, Schlanger, et al., in press) are used. We used the nannoplankton zonation of Leg 90 for Site 586 because it gives the least severe compressions and expansions of the record, and it allows us to compare the records from Sites 586 and 591 without major distortions caused by different age models. However, accepting this biostratigraphic and age model results in the acceptance of the high sedimentation rates for the early to middle Pliocene (Fig. 3).

The data for coarse fraction versus depth (Appendix A) were converted to coarse fraction versus age by calculating a sedimentation rate between each of the nannofossil zone boundaries and linearly interpolating the age of each data point. Bulk-sediment mass accumulation rates (MAR) in $\mathrm{g} / \mathrm{cm}^{2}$ per m.y. were calculated for 0.5 -m.y. intervals in order to eliminate the effects of compaction on linear sedimentation rates and so that calculations of fluxes of components could be made (Fig. 5). Bulk-sediment MAR was calculated using Equations 4 and 5:

$$
\begin{aligned}
\mathrm{DBD} & =(1-\mathrm{P} / 100) \times 2.7 \\
\mathrm{MAR} & =\mathrm{DBD} \times \mathrm{SR} \times 100
\end{aligned}
$$

where $\mathrm{P}$ is the average porosity, DBD is the average dry bulk density, both calculated from the physical properties data (Site 586 and 591 chapters, this volume). SR is the average sedimentation rate, and 2.7 is the average density of calcite.

\section{RESULTS}

\section{Carbonate Data}

The carbonate concentrations for Sites 586 and 591 are plotted versus depth in Figure 2, and the data are tabulated in Appendix B. The carbonate values are so high that even large fluctuations in the flux of carbonate will cause only subtle changes in the carbonate percentages (Gardner, 1975; Dean et al., 1981). There are only 34 data points on the carbonate curve for Site 586 (Fig. 2C), but there appears to be a trend of decreasing carbonate from about $100 \mathrm{~m}$ sub-bottom to the top of the section. The decrease in carbonate began about 4.2 m.y. ago in the early Pliocene. There also appear to be fluctuations of carbonate about the mean throughout the sequence, although, again, it is difficult to detect any character in a curve with so few data points.

The carbonate curve for Site 591 (Fig. 2D) is based on 232 data points, representing an average sample interval of about one sample per meter from the surface to $300 \mathrm{~m}$ sub-bottom. High- and low-frequency cycles of carbonate occur throughout the record. The most noticeable change in the character of the carbonate curve occurs at about $75 \mathrm{~m}$ sub-bottom where the amplitude of carbonate fluctuations changes from about 2 to $3 \%$ below $75 \mathrm{~m}$, to amplitudes of 8 to $10 \%$ above $75 \mathrm{~m}$. This change in the variation occurs at about 2.5 m.y. in the late Pliocene.

The changes in flux of $\mathrm{CaCO}_{3}$ at the two sites are shown by plots of the MAR of $\mathrm{CaCO}_{3}$ for 0.5 -m.y. intervals (Fig. 6). Both sites have very pronounced increases in $\mathrm{CaCO}_{3}$ flux in the late Miocene through midPliocene, then dramatic decreases in $\mathrm{CaCO}_{3}$ flux to the present. Fluxes of $\mathrm{CaCO}_{3}$ were consistently higher at Site 591 than at Site 586 except for the period between 10.5 and 6.5 m.y., when Site 586 received about $50 \%$ more carbonate than did Site 591 and the period of the last $0.5 \mathrm{~m}$.y. when Site 586 received about twice the flux of $\mathrm{CaCO}_{3}$ as did Site 591 .

\section{Coarse-Fraction Data}

The coarse-fraction data are presented in Figures 7 and 8 in four size fractions; the fraction $>147 \mu \mathrm{m}$, the fraction 63-147 $\mu \mathrm{m}$, the fraction $>63 \mu \mathrm{m}$, and the fraction $<63 \mu \mathrm{m}$. Observations from smear slides indicate that the size fractions of $>147 \mu \mathrm{m}$ and $63-147 \mu \mathrm{m}$ are 

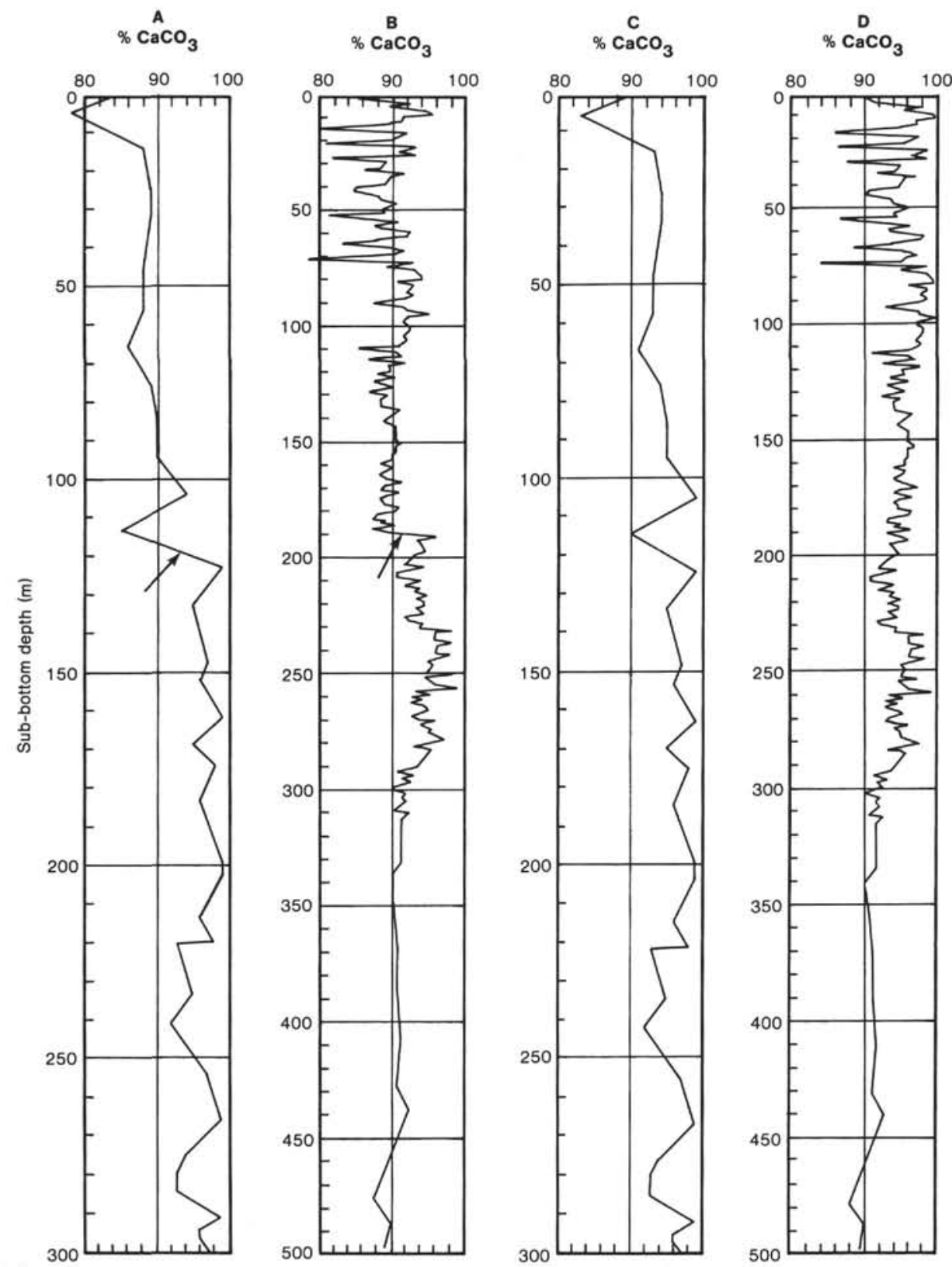

Figure 2. Plots of percent $\mathrm{CaCO}_{3}$ determined by shipboard carbonate bomb for Site 586 (A) and Site 591 (B), and adjusted for shipboard calibration errors for Site 586 (C) and Site 591 (D). See text for method of adjustment. The arrows on Figure 2A,B indicate the location of the step changes in carbonate caused by the shipboard calibration error.

composed entirely of planktonic foraminifers. The $<63$ $\mu \mathrm{m}$ fraction is composed almost entirely of nannofossils and juvenile planktonic foraminifers.

The coarse-fraction data from all four size fractions from Site 586 (Fig. 7) show persistent long-term and short-term trends. In general, the concentrations of the $>147-\mu \mathrm{m}$ fraction are lower than the mean value below $100 \mathrm{~m}$ sub-bottom and higher than the mean value above $100 \mathrm{~m}$. However, there is a persistent trend of increasing $>147-\mu \mathrm{m}$ fraction from $120 \mathrm{~m}$ to the surface. The percentage of the $<63-\mu \mathrm{m}$ fraction is consistently above the mean from 300 to $140 \mathrm{~m}$ sub-bottom, then generally decreases to the top of the core. The concentrations of the $63-147-\mu \mathrm{m}$ fraction vary around the mean value with no consistent trends.
The coarse-fraction data for Site 591 are complete only for the $>63-\mu \mathrm{m}$ and $<63-\mu \mathrm{m}$ fractions (Fig. 8). The $>147-\mu \mathrm{m}$ percentages are consistently less than about $4 \%$ below $120 \mathrm{~m}$ sub-bottom, and the amounts of material $>147-\mu \mathrm{m}$ were so small that significant errors in weighing could occur. We therefore stopped sieving for the $>147-\mu \mathrm{m}$ fraction at the $120-\mathrm{m}$ level but continued to measure the $>63-\mu \mathrm{m}$ fraction. The $<63-\mu \mathrm{m}$ fraction shows trends that are similar to those from Site 586 with both high- and low-frequency cycles of grain size, but the details of the distributions of grain size with depth are somewhat different. The $<63-\mu \mathrm{m}$ fraction is generally above the mean value from 480 to about $120 \mathrm{~m}$ subbottom but with zones of below mean values, especially between 440 and $420 \mathrm{~m}$ and between 302 and $295 \mathrm{~m}$. 
Table 1. Ages (m.y.) of tops of nannofossil zones used to interpolate age for each sample (from Introduction, this volume).

\begin{tabular}{cr} 
Nannofossil zone & Age (m.y.) \\
\hline NN21 & 0.00 \\
NN20 & 0.20 \\
NN19 & 0.55 \\
NN18 & 1.90 \\
NN17 & 2.30 \\
NN16 & 2.40 \\
NN15 & 3.45 \\
NN14 & 3.65 \\
NN13 & 4.10 \\
NN12 & 4.60 \\
NN11b & 5.20 \\
NN11a & 6.25 \\
NN10 & 9.50 \\
NN9 & 11.00 \\
NN8 & 12.00
\end{tabular}

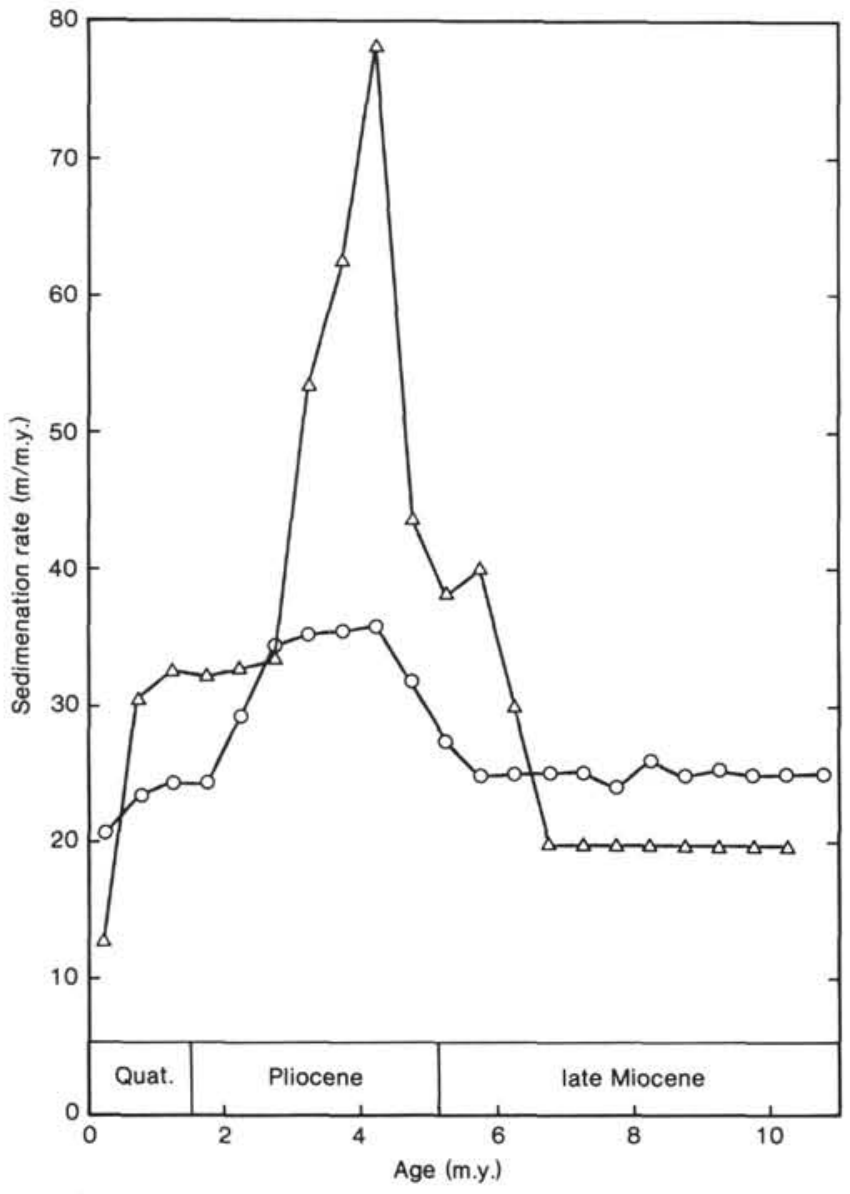

Figure 3. Plots of sedimentation rates in $\mathrm{m} / \mathrm{m}$.y. averaged for 0.5 -m.y. intervals versus age for Site 586 (circles) and Site 591 (triangles).

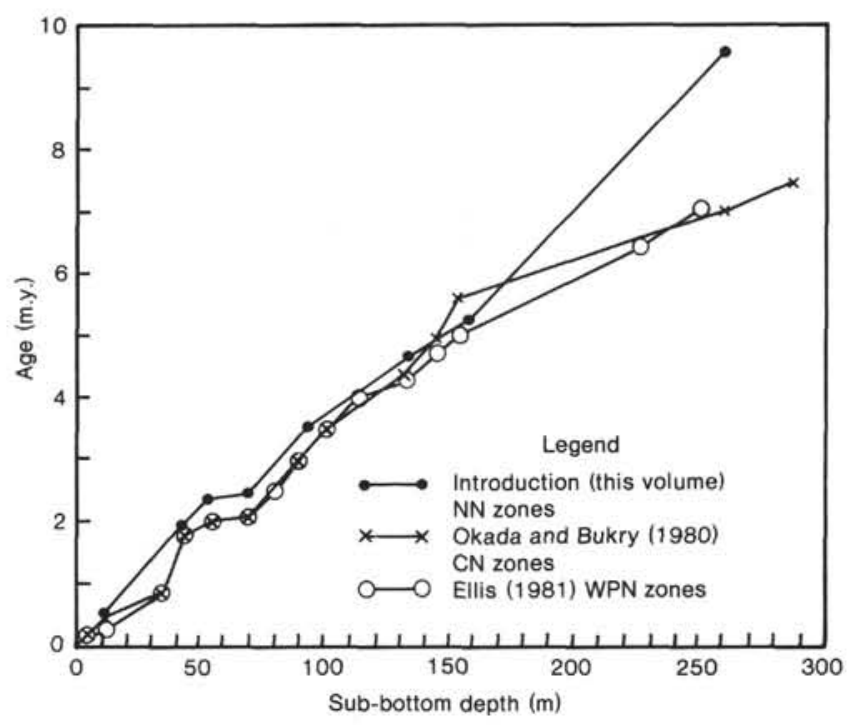

Figure 4. Age versus depth curves for Site 586 using nannofossil zonations and ages from Introduction (this volume), Okada and Bukry (1980), and Ellis (1981).

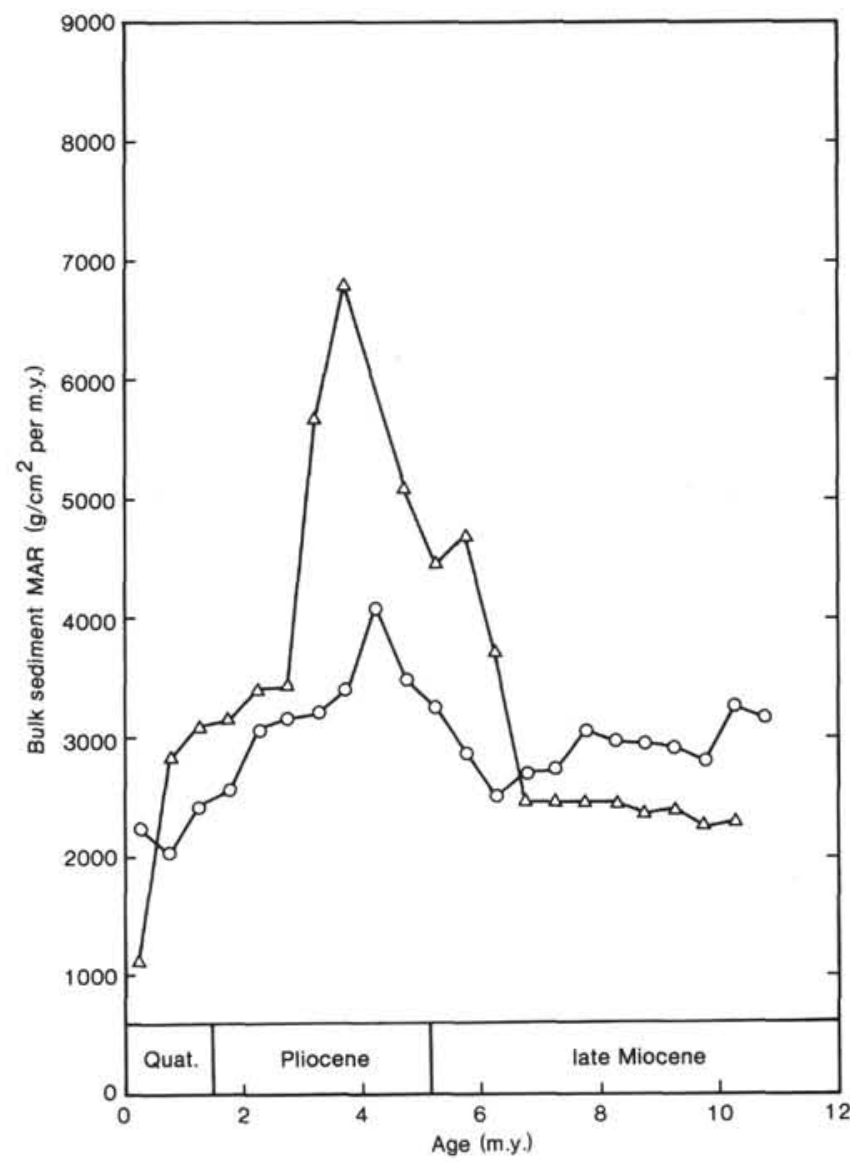

Figure 5. Plots of bulk-sediment mass accumulation rates (MAR; in $\mathrm{g} / \mathrm{cm}^{2}$ per m.y.) averaged for 0.5 -m.y. intervals versus age for Site 586 (circles) and Site 591 (triangles). 


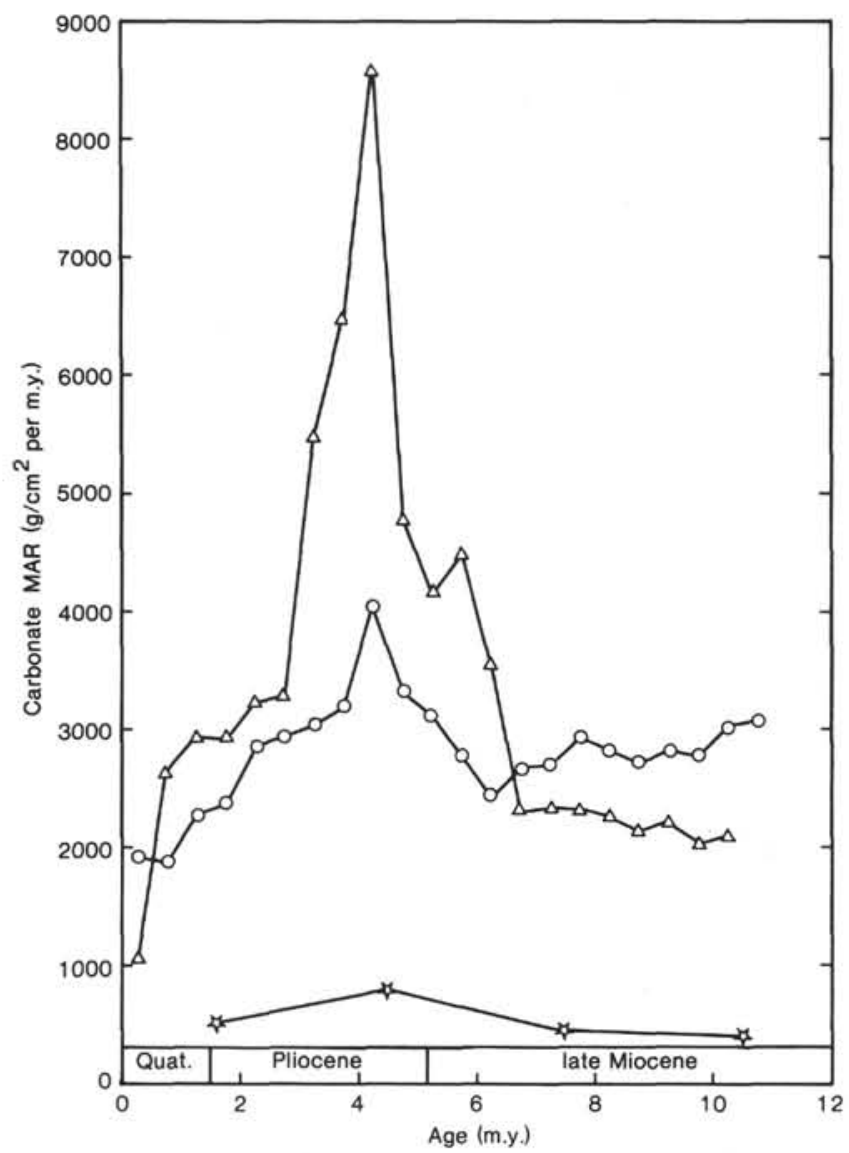

Figure 6. Plots of $\mathrm{CaCO}_{3}$ mass accumulation rates (MAR; $\mathrm{g} / \mathrm{cm}^{2}$ per m.y.) averaged for $0.5-\mathrm{m} . y$. intervals versus age for Site 586 (circles) and Site 591 (triangles). The lowest plot (stars) represents the average carbonate MARs for the entire Pacific Ocean (from Davies and Worsley, 1981).

The $<63-\mu \mathrm{m}$ fraction has a persistent trend of decreasing percentages from about $230 \mathrm{~m}$ to the top of the section, similar to the trend above $100 \mathrm{~m}$ at Site 586 .

In order to investigate the nature of the variations in coarse fraction and to compare the coarse-fraction stratigraphies from Sites 586 and 591 , it was necessary to replot the coarse-fraction abundance data versus age (Figs. 9, 10). These data were subdivided into 0.5-m.y. intervals and various parameters were calculated for each interval (Tables 2, 3).

Plots of the mean percentage of coarse fraction $>63$ $\mu \mathrm{m}$ in each 0.5 -m.y. interval (Fig. 11) show that the two sites have similar trends in coarse fraction with time, but that Site 586 consistently has more than twice the percentage (and as much as five times) of the $>63-\mu \mathrm{m}$ fraction than does Site 591. The overall trend in coarse fraction is a pronounced low abundance at both sites that lasted from the late Miocene into the early Pliocene (about 9 to $4.5 \mathrm{~m}$.y. ago). Coarse fraction generally increased from about 4.5 m.y. to the late Quaternary at both sites, but there are significant fluctuations, particularly at Site 586 .

The variation in coarse-fraction values is shown in Figure 11 as the coefficient of variation (c.v.), which is the standard deviation expressed as a percentage of the mean $[(\mathrm{X} / \mathrm{SD}) \cdot 100]$. The variations in the coarse-fraction data from the two sites are different in magnitude, although they are similar in trend. Clearly, there is greater variability in coarse fraction at Site 591 than at Site 586. The $>63-\mu \mathrm{m}$ fraction from Site 586 has c.v. values that range between 15 and $30 \%$, whereas the same size fraction from Site 591 has c.v. values that range from less than 10 to greater than $30 \%$.

\section{CAUSES OF COARSE-FRACTION VARIATION}

The entire coarse-fraction component $>63 \mu \mathrm{m}$ from Sites 586 and 591 is composed of planktonic foraminifers. The material $<63 \mu \mathrm{m}$ is principally composed of nannofossils and juvenile foraminifers. The shipboard smear-slide summaries (see site chapters, this volume) and shore-based observations reveal that very little material other than foraminifers and nannofossils is present in the sediment. Consequently, the significance of fluctuations in coarse fraction can be interpreted as the result of one or a combination of the following conditions: (1) fluctuations in size-selective dissolution of biogenic carbonate; (2) fluctuations in the rates of production and accumulation of nannofossils relative of those of foraminifers; and (3) fluctuations in amount of winnowing of the fine biogenic components.

Dissolution would tend to break down the foraminiferal tests into fragments and produce a decrease in coarse fraction $(>63 \mu \mathrm{m})$ and an increase in fine fraction $(<63$ $\mu \mathrm{m})$ (Berger et al., 1982). However, we have discounted dissolution as a cause of fluctuations in coarse fraction because both sites are well above the depth of the present lysocline of 3400 to $3600 \mathrm{~m}$ (Berger et al., 1977, 1982). The depths of the Pacific lysocline and calcite compensation depth (CCD) have been below their present depths since the early Oligocene (van Andel et al., 1977), and there are no indications that either Ontong-Java Plateau or Lord Howe Rise were ever significantly deeper than their present depths (Burns, Andrews, et al., 1973; Andrews, Packham, et al., 1975). Shipboard paleontologists noted good to excellent preservation of calcareous microfossils in Quaternary through lower Pliocene sediment at both sites but, in general, the preservation of nannofossils decreases with depth. Noticeable overgrowths were observed on nannofossils in the lowermost Pliocene and older sediment at Site 586 and in upper Miocene and older sediment at Site 591. The fluctuations in coarse fraction do not follow the pattern of observed overgrowths, but occur throughout the record from the late Miocene through the Holocene. This is another reason why we believe that dissolution can be discounted here.

The second process that can cause fluctuations in coarse fraction is variation in accumulation of fine $(<63 \mu \mathrm{m})$ material. If a locality was a depocenter of material that had been winnowed from upstream, or if productivity in the surface waters significantly increased, thus producing a higher flux of nannofossils than normal, then the fine-fraction $(<63 \mu \mathrm{m})$ component would dilute the coarser foraminiferal component. There is no evidence from the bathymetry of either area to suggest that they may have periodically been preferred sites of 

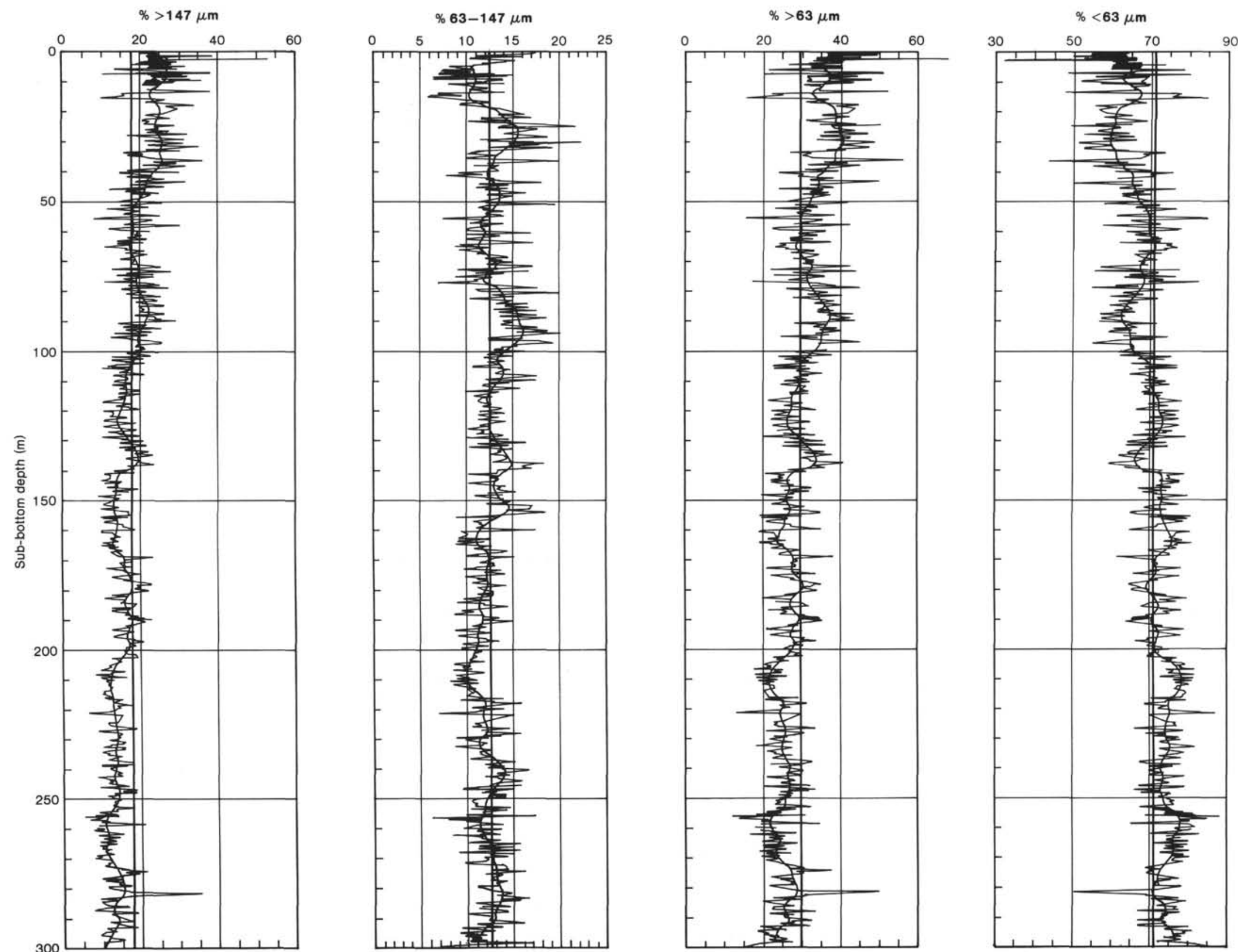

Figure 7. Plots of $\%>147 \mu \mathrm{m}, \%$ 63-147 $\mu \mathrm{m}, \%>63 \mu \mathrm{m}$, and $\%<63 \mu \mathrm{m}$ versus depth for sediments from Site 586. Heavy lines through the data plots are smoothed curves com puted using a 21-point moving average. The heavy vertical line through each plot is located at the mean value for each parameter. 

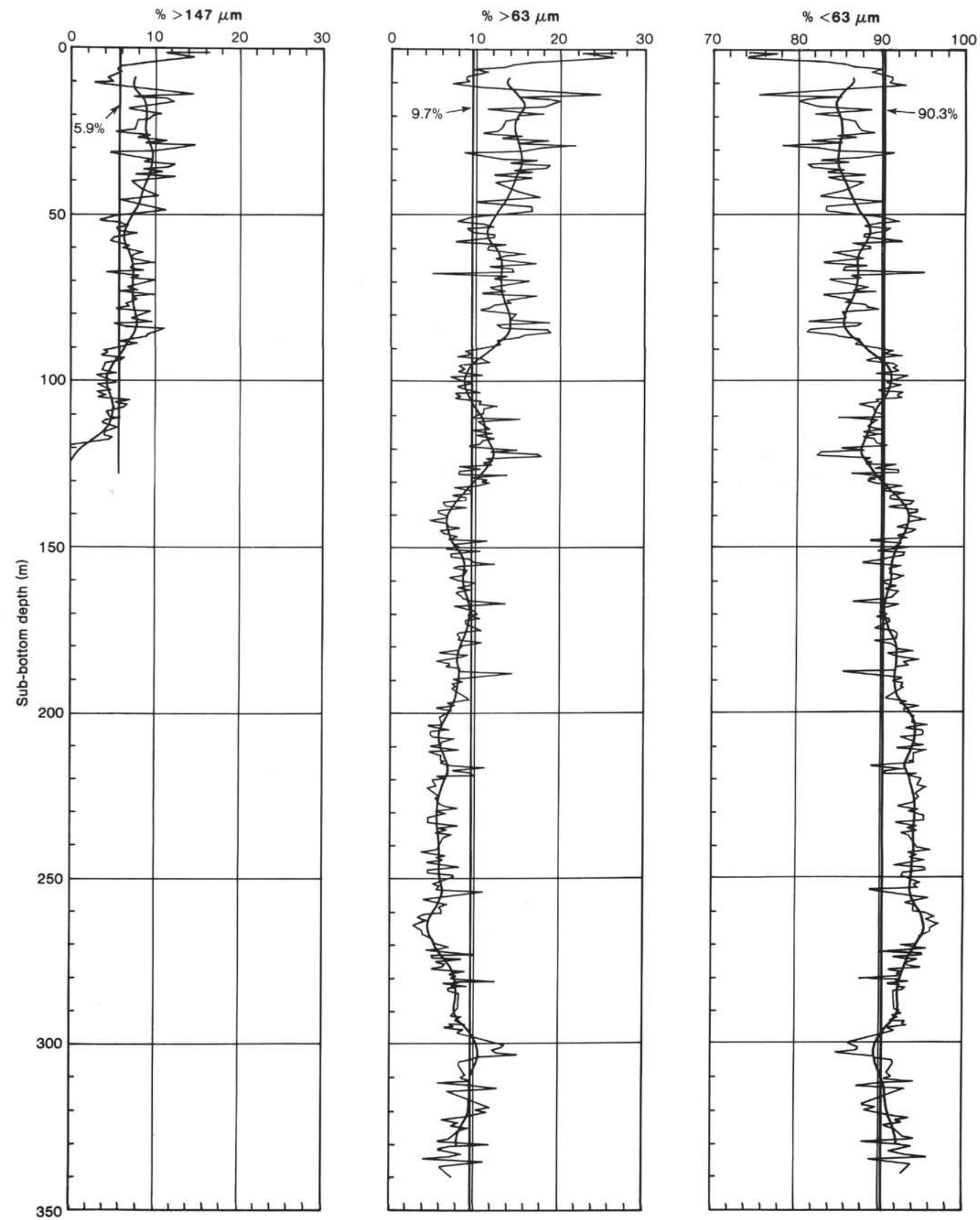

Figure 8. Plots of $\%>147 \mu \mathrm{m}, \%<63 \mu \mathrm{m}$, and $\%>63 \mu \mathrm{m}$ versus depth for sediments from Site 591 . Heavy lines through the data plots are smoothed curves computed using a 21-point moving average. The heavy vertical line through each plot is located at the mean value for each parameter. 

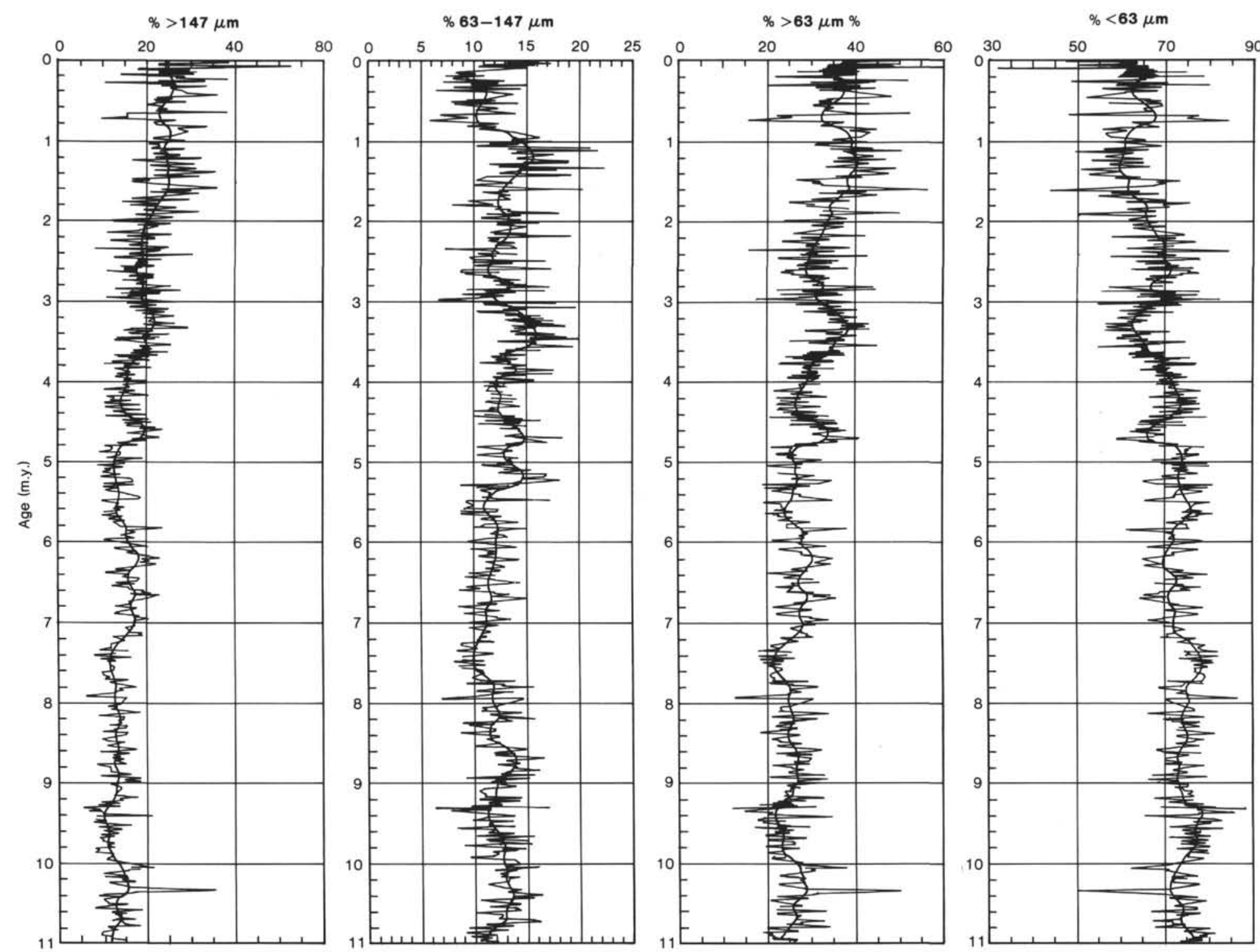

Figure 9. Plots of $\%>147 \mu \mathrm{m}, \% 63-147 \mu \mathrm{m}, \%>63 \mu \mathrm{m}$, and $\%<63 \mu \mathrm{m}$ versus age for sediments from Site 586 . Heavy lines through the data plots are smoothed curves computed using a 21 -point moving average. 

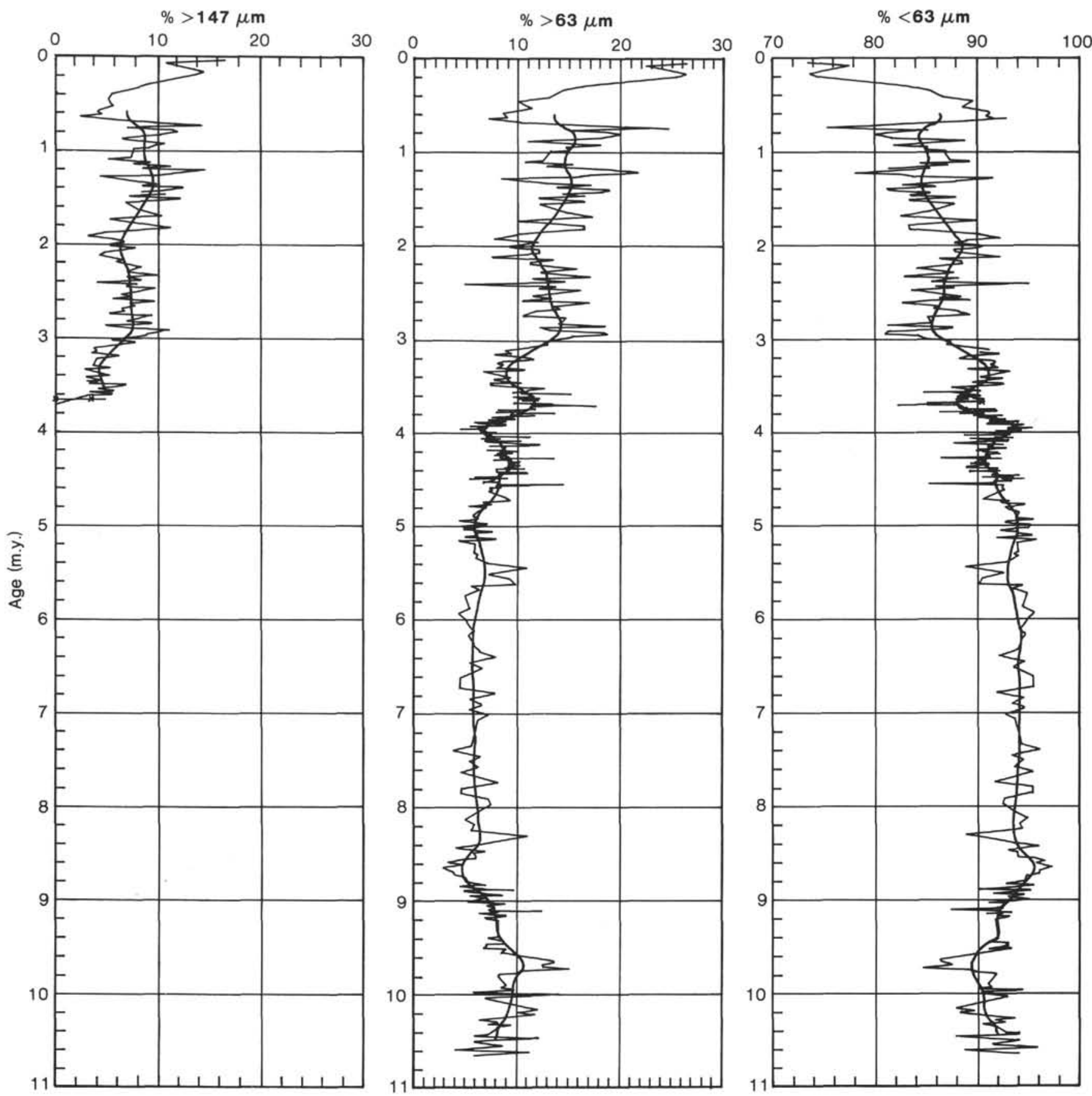

Figure 10. Plots of $\%<147 \mu \mathrm{m}, \%>63 \mu \mathrm{m}$, and $\%<63 \mu \mathrm{m}$ versus age for sediments from Site 591 . Heavy lines through the data plots are smoothed curves computed using a 21-point moving average.

accumulation of current-transported fine materials. Variations in nannofossil productivity, however, may have occurred. Both sites are presently located close to oceanographic diverences (Fig. 1); Site 586 is near the Equatorial Divergence and Site 591 is beneath the Subtropical Divergence. Any overall change in the strength of regional surface circulation should have had exaggerated effects at both sites and in the same way; that is, if circulation strengthened, then the divergence should have become stronger and productivity should have increased. An area of high primary production, such as an upwelling region or a divergence, preferentially should produce a larger flux of phytoplankton (nannofossils and diatoms) than zooplankton (foraminifers and radiolarians). Consequently, an area of high productivity might well produce sediment with higher percentages of finer material relative to an area with low productivity. This process would allow the coarse-fraction record to be interpreted as a record of paleoproductivity.

The third process that can produce changes in the coarse-fraction content is variation in winnowing effects. Currents competent to erode and transport fine $(<63$ $\mu \mathrm{m})$ material would increase the coarse fraction ( $>63$ $\mu \mathrm{m})$ at the expense of the fine fraction (see, e.g., Thiede, 
Table 2. Summary of the mass accumulation rates (MAR) of the grain-size fractions for DSDP Site 586.

\begin{tabular}{|c|c|c|c|c|c|c|c|c|c|c|c|c|c|}
\hline $\begin{array}{l}\text { Depth } \\
\text { range } \\
(\mathrm{m})\end{array}$ & $\begin{array}{l}\text { Age } \\
\text { range } \\
\text { (m.y.) }\end{array}$ & $\begin{array}{l}\text { Sed. } \\
\text { rate } \\
(\mathrm{m} / \mathrm{m} . \mathrm{y})\end{array}$ & $\begin{array}{c}\text { Avg. } \\
>147 \mu \mathrm{m}\end{array}$ & $\begin{array}{l}\text { Avg. } \\
63-147 \mu \mathrm{m}\end{array}$ & $\begin{array}{l}\text { Avg. } \\
<63 \mu \mathrm{m}\end{array}$ & $\begin{array}{c}\text { Avg. } \\
>63 \mu \mathrm{m}\end{array}$ & $\begin{array}{l}\text { Avg. } \\
\text { carb. }\end{array}$ & $\begin{array}{l}\text { MAR } \\
\text { bulk }\end{array}$ & $\begin{array}{c}\text { MAR } \\
>147 \mu \mathrm{m}\end{array}$ & $\begin{array}{c}\text { MAR } \\
63-147 \mu \mathrm{m}\end{array}$ & $\begin{array}{c}\text { MAR } \\
<63 \mu \mathrm{m}\end{array}$ & $\begin{array}{c}\text { MAR } \\
>63 \mu \mathrm{m}\end{array}$ & $\begin{array}{l}\text { MAR } \\
\text { carb. }\end{array}$ \\
\hline $0.0-10.3$ & $0.0-0.5$ & 20.6 & 26.6 & 11.4 & 62.0 & 38.0 & 86 & 2241.4 & 596.2 & 255.5 & 1389.7 & 851.7 & 1927.6 \\
\hline $10.4-22.0$ & $0.5-1.0$ & 23.4 & 23.5 & 11.2 & 65.3 & 34.7 & 93 & 2021.7 & 475.1 & 226.4 & 1320.2 & 701.5 & 1880.2 \\
\hline $22.1-34.3$ & $1.0-1.5$ & 24.4 & 24.7 & 14.9 & 60.4 & 39.6 & 94 & 2424.3 & 598.8 & 361.2 & 1464.3 & 960.0 & 2278.9 \\
\hline $34.4-46.4$ & $1.5-2.0$ & 24.2 & 23.5 & 12.6 & 63.9 & 36.1 & 93 & 2548.2 & 598.8 & 321.0 & 1628.3 & 919.9 & 2369.8 \\
\hline $46.5-61.0$ & $2.0-2.5$ & 29.2 & 18.6 & 12.6 & 68.8 & 31.2 & 93 & 3074.7 & 571.9 & 387.4 & 2115.4 & 959.3 & 2859.5 \\
\hline $61.1-78.2$ & $2.5-3.0$ & 34.4 & 18.6 & 12.0 & 69.4 & 30.6 & 93 & 3157.9 & 587.3 & 378.9 & 2191.6 & 966.3 & 2936.8 \\
\hline $78.3-95.8$ & $3.0-3.5$ & 35.2 & 20.6 & 15.1 & 64.3 & 35.7 & 95 & 3193.3 & 657.8 & 482.1 & 2053.3 & 1140.0 & 3033.6 \\
\hline $95.9-113.5$ & $3.5-4.0$ & 35.4 & 17.6 & 13.7 & 68.7 & 31.3 & 94 & 3393.0 & 597.1 & 464.8 & 2331.0 & 1062.0 & 3189.5 \\
\hline $113.6-131.4$ & $4.0-4.5$ & 35.8 & 15.3 & 12.5 & 72.2 & 27.8 & 99 & 4079.0 & 624.0 & 509.8 & 2945.0 & 1133.9 & 4038.2 \\
\hline $131.5-147.3$ & $4.5-5.0$ & 31.8 & 16.7 & 13.8 & 69.5 & 30.5 & 95 & 3485.9 & 582.1 & 481.0 & 2422.7 & 1063.2 & 3311.6 \\
\hline $147.4-160.3$ & $5.0-5.5$ & 27.4 & 13.2 & 13.2 & 73.6 & 26.4 & 96 & 3255.1 & 429.6 & 429.6 & 2395.7 & 859.3 & 3124.9 \\
\hline $161.1-173.4$ & $5.5-6.0$ & 24.8 & 14.4 & 11.6 & 74.0 & 26.0 & 97 & 2859.1 & 411.7 & 331.6 & 2115.8 & 743.3 & 2773.4 \\
\hline $173.5-185.9$ & $6.0-6.5$ & 25.0 & 17.0 & 12.0 & 71.0 & 29.0 & 97 & 2497.5 & 424.5 & 299.7 & 1773.2 & 724.2 & 2422.5 \\
\hline $186.0-198.4$ & $6.5-7.0$ & 25.0 & 17.0 & 11.3 & 71.7 & 28.3 & 99 & 2700.0 & 459.0 & 305.1 & 1935.9 & 764.1 & 2673.0 \\
\hline $198.5-211.0$ & $7.0-7.5$ & 25.2 & 14.0 & 10.3 & 75.7 & 24.3 & 99 & 2721.6 & 381.0 & 280.3 & 2060.2 & 661.3 & 2694.3 \\
\hline $211.1-223.0$ & $7.5-8.0$ & 24.0 & 12.4 & 11.2 & 76.4 & 23.6 & 96 & 3058.5 & 379.2 & 342.5 & 2336.7 & 721.8 & 2936.2 \\
\hline $223.1-236.0$ & $8.0-8.5$ & 26.0 & 13.4 & 11.6 & 75.0 & 25.0 & 95 & 2962.4 & 396.9 & 343.6 & 2221.8 & 740.6 & 2814.3 \\
\hline $236.1-248.4$ & $8.5-9.0$ & 24.8 & 13.6 & 13.4 & 73.0 & 27.0 & 92 & 2946.2 & 400.6 & 394.7 & 2150.7 & 795.4 & 2710.5 \\
\hline $248.5-261.0$ & $9.0-9.5$ & 25.2 & 11.8 & 11.6 & 76.6 & 23.4 & 97 & 2912.1 & 343.6 & 337.8 & 2230.6 & 681.4 & 2824.7 \\
\hline $261.1-273.4$ & $9.5-10.0$ & 24.8 & 11.4 & 12.6 & 76.0 & 24.0 & 99 & 2798.9 & 319.0 & 352.6 & 2127.1 & 671.7 & 2770.9 \\
\hline $273.5-285.9$ & $10.0-10.5$ & 25.0 & 14.8 & 13.3 & 71.9 & 28.1 & 93 & 3253.5 & 481.5 & 432.7 & 2339.2 & 914.2 & 3025.7 \\
\hline $286.0-298.4$ & $10.5-11.0$ & 25.0 & 12.8 & 12.3 & 74.9 & 25.1 & 97 & 3159.0 & 404.3 & 388.5 & 2366.0 & 792.9 & 3064.2 \\
\hline
\end{tabular}

Table 3. Summary of the mass accumulation rate (MAR) of the grain-size fractions for DSDP Site 591.

\begin{tabular}{|c|c|c|c|c|c|c|c|c|c|c|c|c|c|}
\hline $\begin{array}{l}\text { Depth } \\
\text { range } \\
\text { (m) }\end{array}$ & $\begin{array}{l}\text { Age } \\
\text { range } \\
\text { (m.y.) }\end{array}$ & $\begin{array}{l}\text { Sed. } \\
\text { rate } \\
(\mathrm{m} / \mathrm{m} \cdot \mathrm{y} .)\end{array}$ & $\begin{array}{c}\text { Avg. } \\
>147 \mu \mathrm{m}\end{array}$ & $\begin{array}{l}\text { Avg. } \\
63-147 \mu \mathrm{m}\end{array}$ & $\begin{array}{c}\text { Avg. } \\
<63 \mu \mathrm{m}\end{array}$ & $\begin{array}{l}\text { Avg. } \\
>63 \mu \mathrm{m}\end{array}$ & $\begin{array}{l}\text { Avg. } \\
\text { carb. }\end{array}$ & $\begin{array}{c}\text { MAR } \\
\text { bulk }\end{array}$ & $\begin{array}{c}\text { MAR } \\
>147 \mu \mathrm{m}\end{array}$ & $\begin{array}{c}\text { MAR } \\
63-147 \mu \mathrm{m}\end{array}$ & $\begin{array}{c}\text { MAR } \\
<63 \mu \mathrm{m}\end{array}$ & $\begin{array}{c}\text { MAR } \\
>63 \mu \mathrm{m}\end{array}$ & $\begin{array}{l}\text { MAR } \\
\text { carb. }\end{array}$ \\
\hline $0.00-6.35$ & $0.0-0.5$ & 12.7 & 10.7 & 19.4 & 69.9 & 30.1 & 94.0 & 1114.4 & 119.2 & 216.2 & 779.0 & 335.4 & 1047.6 \\
\hline $6.35-21.67$ & $0.5-1.0$ & 30.6 & 8.3 & 14.3 & 77.6 & 22.4 & 94.6 & 2817.3 & 233.8 & 402.9 & 2186.3 & 631.1 & 2665.2 \\
\hline $21.67-37.97$ & $1.0-1.5$ & 32.6 & 9.3 & 15.0 & 75.8 & 24.2 & 95.2 & 3098.3 & 288.1 & 464.7 & 2348.5 & 749.8 & 2949.6 \\
\hline $37.97-54.00$ & $1.5-2.0$ & 32.1 & 7.7 & 13.0 & 78.8 & 21.2 & 92.7 & 3146.1 & 242.3 & 409.0 & 2479.1 & 667.0 & 2916.5 \\
\hline $54.00-70.33$ & $2.0-2.5$ & 32.7 & 7.0 & 12.4 & 80.8 & 19.2 & 95.1 & 3408.0 & 238.6 & 422.6 & 2753.7 & 654.3 & 3241.0 \\
\hline $70.33-86.98$ & $2.5-3.0$ & 33.3 & 7.8 & 14.2 & 78.0 & 22.0 & 96.8 & 3398.6 & 265.1 & 482.6 & 2650.9 & 747.7 & 3289.8 \\
\hline $86.98-113.74$ & $3.0-3.5$ & 53.5 & 4.7 & 9.4 & 85.8 & 14.2 & 97.3 & 5648.0 & 265.5 & 530.9 & 4846.0 & 802.0 & 5495.5 \\
\hline $113.74-145.06$ & $3.5-4.0$ & 62.6 & & & 88.6 & 11.4 & 95.0 & 6794.6 & & & 6020.0 & 774.6 & 6454.9 \\
\hline $145.06-184.22$ & $4.0-4.5$ & 78.3 & & & 91.2 & 8.8 & 95.3 & 9006.1 & & & 8213.5 & 792.5 & 8482.8 \\
\hline $184.22-206.00$ & $4.5-5.0$ & 43.6 & & & 92.7 & 7.3 & 94.0 & 5085.5 & & & 4714.3 & 371.2 & 4780.4 \\
\hline $206.00-225.00$ & $5.0-5.5$ & 38.0 & & & 93.5 & 6.5 & 93.4 & 4442.6 & & & 4153.8 & 288.8 & 4149.4 \\
\hline $225.00-245.00$ & $5.5-6.0$ & 40.0 & & & 94.1 & 5.9 & 95.7 & 4687.2 & & & 4410.7 & 276.5 & 4485.7 \\
\hline $245.00-259.95$ & $6.0-6.5$ & 29.9 & & & 93.7 & 6.2 & 95.5 & 3713.6 & & & 3479.6 & 230.2 & 3546.5 \\
\hline $259.95-269.85$ & $6.5-7.0$ & 19.8 & & & 95.3 & 4.7 & 94.0 & 2459.2 & & & 2343.6 & 115.6 & 2311.6 \\
\hline $269.85-279.75$ & $7.0-7.5$ & 19.8 & & & 94.1 & 5.9 & 95.4 & 2459.2 & & & 2314.1 & 145.1 & 2346.0 \\
\hline $279.75-289.65$ & $7.5-8.0$ & 19.8 & & & 92.2 & 7.8 & 94.8 & 2459.2 & & & 2267.3 & 191.8 & 2331.3 \\
\hline $289.65-299.55$ & $8.0-8.5$ & 19.8 & & & 92.1 & 7.9 & 92.2 & 2459.2 & & & 2264.9 & 194.3 & 2267.3 \\
\hline $299.55-309.45$ & $8.5-9.0$ & 19.8 & & & 88.6 & 11.4 & 91.4 & 2352.2 & & & 2084.1 & 268.2 & 2149.9 \\
\hline $309.45-319.35$ & $9.0-9.5$ & 19.8 & & & 90.9 & 9.1 & 92.1 & 2405.7 & & & 2186.8 & 218.9 & 2215.6 \\
\hline $319.35-329.25$ & $9.5-10.0$ & 19.8 & & & 91.0 & 9.0 & 90.8 & 2245.3 & & & 2043.2 & 202.1 & 2038.8 \\
\hline $329.25-339.15$ & $10.0-10.5$ & 19.8 & & & 92.4 & 7.6 & 91.6 & 2298.8 & & & 2124.1 & 174.7 & 2105.7 \\
\hline
\end{tabular}

1977). We use winnowing to mean a process that either erodes and transports some, but not necessarily all, of the fine components or causes selective nondeposition of that fine fraction leaving the coarse components relatively intact. We do not mean an erosive process that eliminates entire deposits. Erosion of an entire deposit will cause a hiatus and should be recognized by absent or highly compressed biostratigraphic zones and very slow sedimentation rates. The recovery of all biostratigraphic zones of both planktonic foraminifers and nannofossils at Sites 586 and 591 indicates that there were no erosional events strong enough to remove an entire biostratigraphic zone, although minor erosional events of up to several tens of thousands of years may have occurred.

\section{Long-Term Trends}

From our discussion on causes of coarse-fraction variations in the previous section, we concluded that dissolution could not be an important process at either Sites 586 or 591 , but that productivity of calcareous plankton and current winnowing both may have been important processes. In this section we discuss how these two processes may have been responsible for the observed variations in the coarse-fraction records on Lord Howe Rise and Ontong-Java Plateau. The basis for this discussion will be the plots for $0.5-\mathrm{m}$.y. intervals of average values of the $>63-\mu \mathrm{m}$ fraction (Fig. 11), average sedmentation rates (Fig. 3), average bulk-sediment MAR (Fig. 5), and average MAR for each size fraction (Fig. 12). 


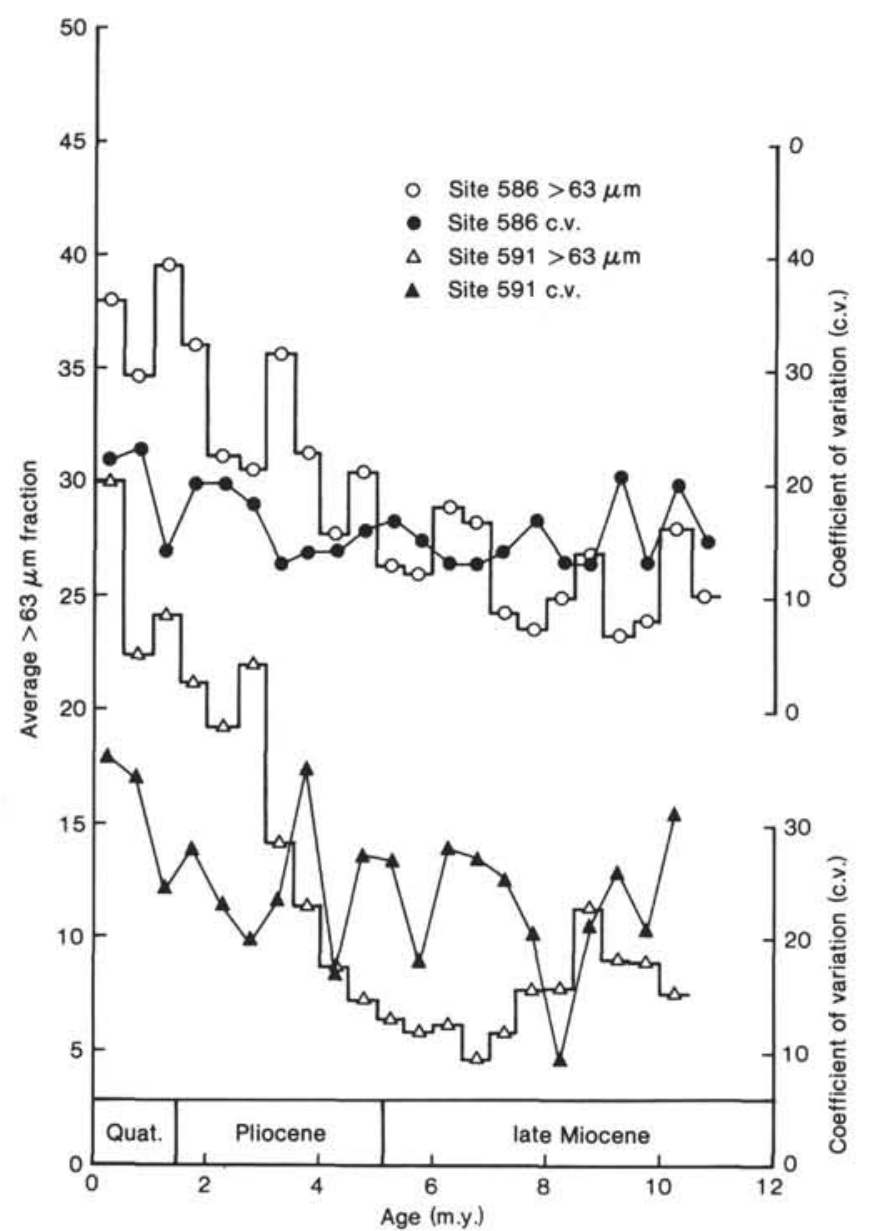

Figure 11. Histograms of percent coarse fraction ( $>63 \mu \mathrm{m}$ ) averaged for $0.5-\mathrm{m}$.y. intervals versus age for Sites 586 and 591. Plots of the coefficient of variation (c.v.; standard deviation as the percent of mean) for each 0.5-m.y. interval are shown for each site below the appropriate histogram.

Based on the plots in Figures 3, 5, 11, and 12, we have subdivided the records at Sites 586 and 591 into five time intervals for purposes of discussion: 10.5 to 6.5 m.y.; 6.5 to 4.0 m.y.; 4.0 to 2.5 m.y.; 2.5 to 0.7 m.y.; 0.7 to the present. Each interval represents different conditions of sediment accumulation at Lord Howe Rise and Ontong-Java Plateau. During the early late Miocene (10.5 to 6.5 m.y.) sedimentation rates at Sites 586 and 591 were relatively typical for sedimentation rates on carbonate platforms outside of high-productivity regions. The sedimentation rate on Lord Howe Rise during this interval was about $20 \mathrm{~m} / \mathrm{m}$.y. and that on Ontong-Java Plateau was about $25 \mathrm{~m} / \mathrm{m}$.y. (Fig. 3). The bulk-sediment MARs of the two areas during this interval were about $2500 \mathrm{~g} / \mathrm{cm}^{2}$ per m.y. for Lord Howe Rise and about $3000 \mathrm{~g} / \mathrm{cm}^{2}$ per m.y. for Ontong-Java Plateau (Fig. 5). These MARs are typical for the southwestern Pacific at that time (Worsley and Davies, 1979). The average coarsefraction ( $>63 \mu \mathrm{m}$ percentages (Fig. 11) and MARs (Fig. 12) were always higher at Site 586 than at Site 591. We interpret this difference to be the result of winnowing of rather nominal sediment fluxes on Ontong-Java Plateau during the early late Miocene. Site 586 has about $30 \%$

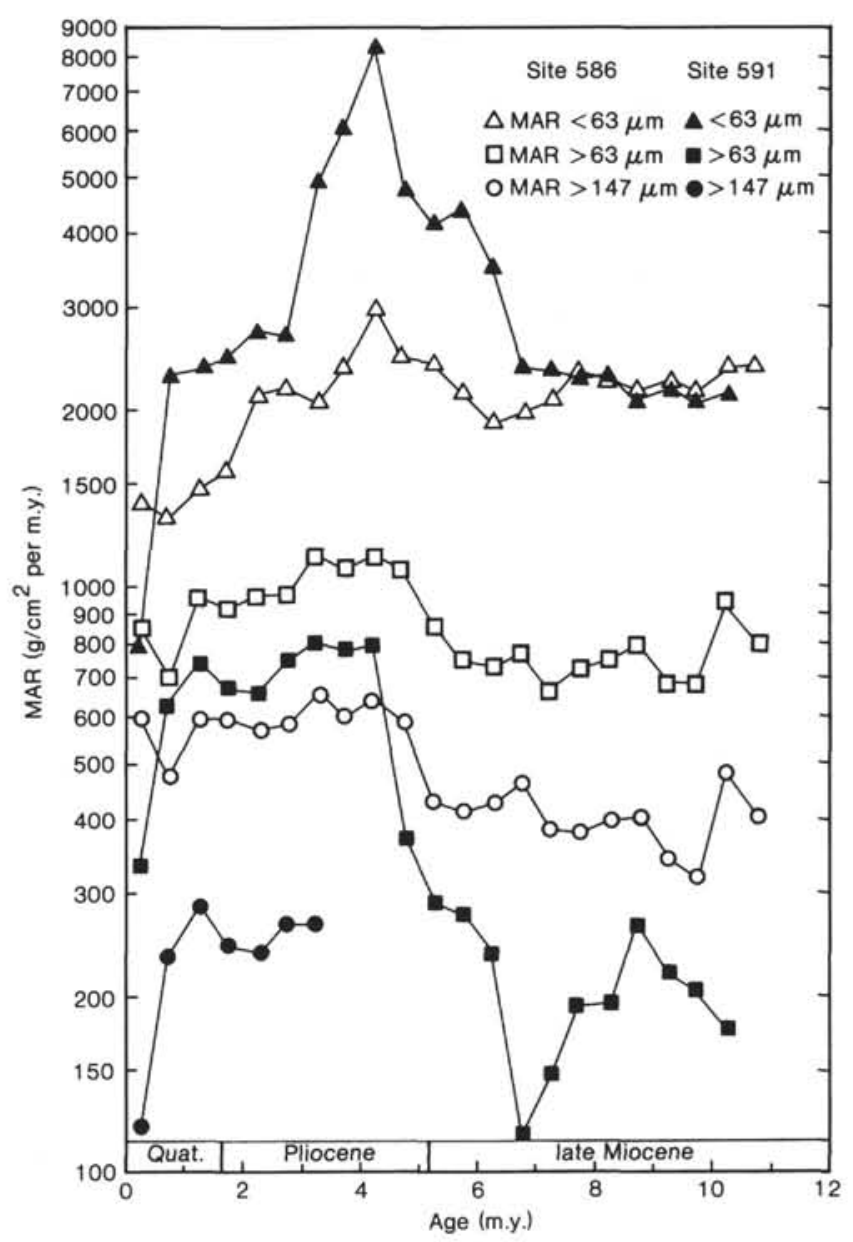

Figure 12. Semilogarithmic plots of mass accumulation rates (MAR; in $\mathrm{g} / \mathrm{cm}^{2}$ per m.y.) averaged for 0.5 -m.y. intervals versus age for the $>147 \mu \mathrm{m},>63 \mu \mathrm{m}$, and $<63 \mu \mathrm{m}$ size fractions in sediments from Sites 586 and 591 .

coarse fraction and about $70 \%$ fine fraction (Fig. 11). If we assume all coarse fraction is foraminifers and $10 \%$ of the fine fraction is juvenile foraminifers, then the ratio of foraminifers to nannofossils is 40:60. The same assumptions applied to Site 591 yield a ratio of foraminifers to nannofossils of $15: 85$. Consequently, it is apparent that Site 586 witnessed stronger winnowing efficiently than did Site 591 during the early late Miocene. We use this period from 10.5 to $6.5 \mathrm{~m}$.y. ago as a baseline for "normal" conditions of productivity and sediment accumulation at both Lord Howe Rise and Ontong-Java Plateau from which to measure changes that occurred later in the records from these two areas. It is important to note that during this period the main Antarctic ice sheet was already formed (Kennett, 1977), but the West Antarctic ice sheet was not yet developed (Ciesielski et al., 1982; Kennett, 1982).

The period of relatively normal sedimentation was followed by a period of very high productivity in the latest Miocene to early Pliocene from 6.5 to 4.0 m.y. ago. The effects apparently were much greater and began about $1 \mathrm{~m} . \mathrm{y}$. earlier on Lord Howe Rise than on Ontong-Java Plateau. Increased productivity is suggested by the large increases in sedimentation rates (Fig. 3) and bulk-sedi- 
ment MARs (Fig. 5), but, more importantly, by the relationships between the size-fraction MARs (Fig. 12). At Site 591 , there is a very large increase in the $<63-\mu \mathrm{m}$ MAR from about 2100 to greater than $8000 \mathrm{~g} / \mathrm{cm}^{2}$ per m.y. (Fig. 12). During this same interval, the $>63-\mu \mathrm{m}$ MAR rose from less than 200 to about $800 \mathrm{~g} / \mathrm{cm}^{2}$ per m.y. Less dramatic but significant increases in size-fraction MARs also occurred on Ontong-Java Plateau where the $<63-\mu$ m MAR went from 2000 to $3000 \mathrm{~g} / \mathrm{cm}^{2}$ per m.y. and the $>63-\mu$ m MAR went from 700 to $1100 \mathrm{~g} /$ $\mathrm{cm}^{2}$ per m.y. The ratio of the coarse- to fine-fraction components changed very little from 6.5 to 4.0 m.y. ago (Fig. 12), further supporting increased productivity during this time. Maximum productivity at Sites 586 and 591 from 6.5 to 4.0 m.y. ago supports the suggestion by Ciesielski et al. (1982) that one effect of the expansion of the Antarctic ice sheet and the growth of the West Antarctic ice sheet beginning about $6.2 \mathrm{~m}$.y. ago was to increase the surface circulation at least of the Southern Ocean. The grain-size stratigraphies suggest that there was increased productivity probably caused by increased upwelling that resulted from the intensification of the Subtropical and Equatorial divergences during this time. This early Pliocene period of maximum productivity on both Lord Howe Rise and Ontong-Java Plateau corresponds to a period of maximum sedimentation rates on the Falkland Plateau (Ciesielski et al., 1982) and maximum carbonate MAR averaged for the entire Pacific Ocean (Davies and Worsley, 1981; Fig. 6).

Productivity appears to have been at a maximum at both Lord Howe Rise and Ontong-Java Plateau in the early Pliocene, about $4 \mathrm{~m}$.y ago. Sedimentation rates at Site 591 abruptly decreased from the maximum of almost $80 \mathrm{~m} / \mathrm{m} . \mathrm{y} .4 .0 \mathrm{~m} . \mathrm{y}$. ago to about $32 \mathrm{~m} . / \mathrm{m}$.y. by $2.5 \mathrm{~m} . \mathrm{y}$. ago. However, sedimentation rates at Site 586 remained high at about $35 \mathrm{~m} / \mathrm{m}$.y. from $4.0 \mathrm{~m}$.y. to about $2.5 \mathrm{~m}$.y. ago and then decreased to a minimum of about $22 \mathrm{~m} / \mathrm{m}$.y. about $2.0 \mathrm{~m} . \mathrm{y}$. ago. There appears to have been a lag of about 0.5 m.y. in the response of sedimentation rates and mass accumulation rates at Ontong-Java Plateau relative to Lord Howe Rise.

The cause of the decreased sedimentation rates can be determined from the grain size MARs (Fig. 12). At both Ontong-Java Plateau and Lord Howe Rise the coarse-fraction component MAR $(>63 \mu \mathrm{m})$ persisted at high values of about 700 to $1000 \mathrm{~g} / \mathrm{cm}^{2}$ per m.y. between 4.0 and $2.5 \mathrm{~m} . \mathrm{y}$. ago, whereas the fine-fraction component MAR $(<63 \mu \mathrm{m})$ significantly decreased. At Site 591 the decrease was from a high of greater than 8000 to a low of about $2500 \mathrm{~g} / \mathrm{cm}^{2}$ per m.y.; at Site 586 the decrease was from a high of 2900 to a low of about $1500 \mathrm{~g} / \mathrm{cm}^{2}$ per m.y. These decreases in fine fraction together with persistently high values of coarse fraction suggest a significant period of winnowing between 4.0 and 2.5 m.y. ago.

By 2.0 m.y. ago sedimentation rates at Ontong-Java Plateau had returned to values similar to those of the late Miocene $(\sim 25 \mathrm{~m} / \mathrm{m} . \mathrm{y}$.$) , but sedimentation rates on$ Lord Howe Rise remained about $50 \%$ higher than late Miocene rates. Both fine fraction and coarse fraction significantly decreased, yet the sedimentation rates do not suggest a hiatus. Consequently, dissolution proba- bly is not the cause of the decreases. It is not possible to determine how much of the sharp decrease in sedimentation rates and sediment MARs between 4.0 and 2.0 m.y. ago was due to winnowing and how much was due to decreased productivity. However, the middle Pliocene ( 4 to 3 m.y. ago) was a period of erosion on the Falkland Plateau (Ciesielski et al., 1982); increase Antarctic Bottom Water circulation in Vema Channel in the South Atlantic (Ledbetter et al., 1978); and high abundance of cold-water Antarctic radiolarians (Keany, 1978). Further, it is represented by a disconformity in the Ross Sea (Hayes, Frakes, et al., 1975). All of these suggest that winnowing was important. A decrease of about $50 \%$ in the carbonate MAR for the entire Pacific Ocean beginning about 4.0 m.y. ago (Davies and Worsley, 1981), however, suggests that productivity also may have decreased.

Significant winnowing and possibly decreased productivity continued between 3.0 and $0.7 \mathrm{~m}$.y. ago, as indicated by the shoulders on the sedimentation rate and MAR curves for this time interval (Figs. 3, 5, 12). Erosion on Lord Howe Rise and Ontong-Java Plateau during this time interval coincides with a period of maximum post-Miocene erosion on the Falkland Plateau (2 to 1 m.y. ago; Ciesielski et al., 1982); several Patagonia glaciations (Fleck et al., 1972; Mercer, 1976); severe glaciation in the Weddell Sea (2.5 to 1.9 m.y. ago; Anderson, 1972); and initiation of Northern Hemisphere glaciation about 2.5 m.y. ago (Kent et al., 1971; Berggren, 1972; Shackleton and Kennett, 1975; Shackleton and Opdyke, 1977; Backman, 1979; Poore, 1981; Kennett, 1983).

The intensity of winnowing increased on Lord Howe Rise during the late Quaternary from $0.7 \mathrm{~m}$.y. ago to the present, but this event did not affect the Ontong-Java Plateau. The evidence for winnowing on Lord Howe Rise can be seen by the marked decreases in MARs of both the fine and coarse fractions (Fig. 12). The $<63-\mu \mathrm{m}$ MAR decreased from 2300 to less than $800 \mathrm{~g} / \mathrm{cm}^{2}$ per m.y., the $>63-\mu$ m MAR decreased from 650 to $340 \mathrm{~g} /$ $\mathrm{cm}^{2}$ per m.y., the $>147-\mu \mathrm{m}$ MAR decreased from 250 to $120 \mathrm{~g} / \mathrm{cm}^{2}$ per m.y., the bulk-sediment MAR decreased from 3000 to $1200 \mathrm{~g} / \mathrm{cm}^{2}$ per m.y. (Fig. 5), and the sedimentation rates decreased from 32 to $12 \mathrm{~m} / \mathrm{m}$.y. (Fig. 3). The average percentage of the coarse fraction also increased considerably during the Pliocene and Quaternary (Fig. 11), lending further support for winnowing during the last $1.0 \mathrm{~m}$.y. This interval of increased winnowing on Lord Howe Rise may have been a local event because it is not found on Ontong-Java Plateau and the last $0.7 \mathrm{~m}$.y. was a period of increased sedimentation on the Falkland Plateau (Ciesielski et al., 1982).

\section{$10^{5}$ and $10^{4}$ Year Cycles}

The plots of coarse fraction versus time (Figs. 9, 10) show that there are distinct fluctuations in grain size on scales of $10^{5}$ and $10^{4} \mathrm{yr}$. cycle. The $10^{4} \mathrm{yr}$. cycles are best seen in the raw data, but the $10^{5}$ yr. cycles are better seen in the 21-point running averages that are drawn through the data. The average periodicity of eleven $10^{5} \mathrm{yr}$. cycles over the past $10 \mathrm{~m} . \mathrm{y}$. at Site 591 is $850 \times 10^{3} \mathrm{yr}$. The av- 
erage periodicity of $25 \times 10^{5} \mathrm{yr}$. cycles over the past 11 m.y. at Site 586 is $430 \times 10^{3}$ yr. The $10^{5}$ yr. cycles at both sites are best developed (have the highest amplitudes) in the last 5 m.y.; prior to 5 m.y. ago, the amplitudes of the cycles are greatly reduced.

In order to determine the periodicities of the $10^{4} \mathrm{yr}$. cycles, we plotted the grain-size data versus age but at a much larger scale than in Figures 9 and 10. We subdivide the age axis into 0.5 -m.y. intervals and counted the number of cycles for each 0.5 -m.y. interval. The periodicities for each 0.5 -m.y. interval at each site are plotted on Figure 13.

The periodicities of the $10^{4} \mathrm{yr}$. cycles range from 100 to $48 \times 10^{3} \mathrm{yr}$./cycle at Site 586 and from 250 to $33 \times$ $10^{3} \mathrm{yr}$./cycle at Site 591 (Fig. 13). The most noticeable characteristic of the grain-size cycles is the change in periodicities that occurred about $5 \mathrm{~m}$.y. ago at both sites. Prior to $5 \mathrm{~m} . \mathrm{y}$. ago, in the late Miocene, periodicities of grain-size cycles at Site 586 varied between about 55 and $80 \times 10^{3} \mathrm{yr}$./cycle with an average periodicity of about $65 \times 10^{3} \mathrm{yr}$./cycle. Then, at about the Miocene/Pliocene boundary, the periodicities of the cycles decreased to an average of about $40 \times 10^{3} \mathrm{yr}$./cycle between 5 and $2.5 \mathrm{~m}$.y. ago, and increased back to an average periodicity of about $65 \times 10^{3} \mathrm{yr}$./cycle between 2.5 and $0.7 \mathrm{~m} . \mathrm{y}$. ago. Because the sedimentation rates and MARs are relatively constant at Site 586 between 11 and 6 m.y. ago and between 2.5 and 0.7 m.y. ago (Figs. 3, 5, 12), the range in periodicities $\left(55\right.$ to $80 \times 10^{3} \mathrm{yr}$./cycle) for these parts of the section probably represents an average range of periodicities for cycles in sediment from this area deposited under relatively stable conditions. The amplitudes of the $10^{4} \mathrm{yr}$. cycles, like the amplitudes of the $10^{5}$ yr. cycles, are much less in the Miocene part of the section. In the post-Miocene part of the section the amplitudes of variation in grain size at all scales are considerably greater.

At Site 591, periodicities of grain-size cycles were generally greater than $100 \times 10^{3} \mathrm{yr}$./cycle during the late Miocene, with considerable variation. Periodicities decreased markedly in the latest Miocene to about $40 \times$ $10^{3} \mathrm{yr}$./cycle by the early Pliocene, and then increased to between 70 and $130 \times 10^{3} \mathrm{yr}$./cycle in the upper Pliocene section and greater than $100 \times 10^{3} \mathrm{yr}$./cycle in the Quaternary section. The shortest periodicities at both sites occur in the Pliocene.

The observed variations in grain-size parameters are the result of fluctuations in winnowing strength and productivity that are directly linked to climatic forcing through fluctuations in surface and subsurface circulation. The periodicities of all of the grain-size cycles are within the range of orbital cycles that have been used to interpret the mechanism of global climate change (Hays et al., 1976; Pisias and Moore, 1981). However, because the periodicities of $10^{4}$ and $10^{5}$ yr. grain-size cycles at Sites 586 and 591 are not similar for any given period and because the periodicities are highly variable over the past 10 m.y., particularly on Lord Howe Rise, we believe that local effects of fluctuations in productivity and winnowing have modified the primary record of climatic forcing. Consequently, the resultant records are

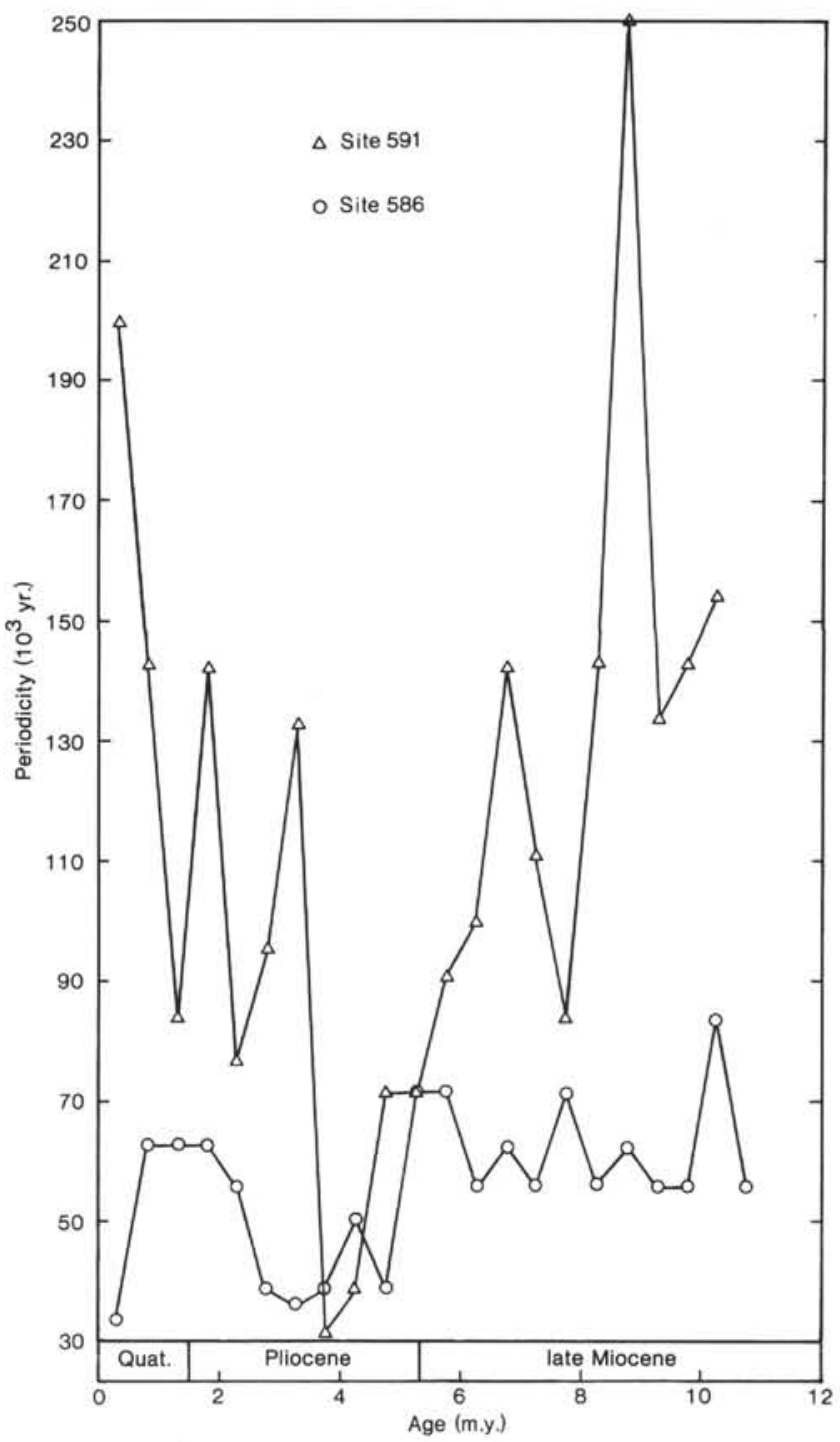

Figure 13. Periodicities of shorter-period cycles in the $>63 \mu \mathrm{m}$ sizefraction records for Site 586 (circles) and Site 591 (triangles) averaged for $0.5-\mathrm{m} . \mathrm{y}$. intervals.

complex products of primary climate signals with superimposed local effects.

\section{CONCLUSIONS}

Ontong-Java Plateau and Lord Howe Rise have both been well above the foraminiferal lysocline and the CCD for at least the last $10 \mathrm{~m}$.y. Therefore, carbonate concentrations are too high to preserve any variations that might be correlated with established carbonate stratigraphies that reflect climate change. However, the grainsize stratigraphies of Sites 586 and 591 do show histories of the influences of current winnowing and phytoplankton productivity on the sediment of Ontong-Java Plateau and Lord Howe Rise that are related to climatic changes.

Conditions of sediment accumulation at both sites were relatively stable during the late Miocene from 10 to $6.5 \mathrm{~m} . \mathrm{y}$. ago. The latest Miocene and early Pliocene was a period of greatly increased nannoplankton productiv- 
ity, influencing the sediment of Lord Howe Rise much more than the sediment of Ontong-Java Plateau. The increased productivity at Lord Howe Rise probably was caused by increased upwelling at the Subtropical Divergence and at Ontong-Java Plateau by increased upwelling at the Equatorial Divergence. The increased upwelling is inferred to have been caused by increased circulation related to the development and expansion of the West Antarctic ice sheet. The period of increased productivity was followed by a period of current winnowing during the late Pliocene ( 4.0 to $2.0 \mathrm{~m}$.y.). The conditions returned to quieter pelagic sedimentation until about 0.7 m.y. ago when another episode of current winnowing commenced on Lord Howe Rise but not on OntongJava Plateau.

The periodicities of the cycles of grain-size fluctuations are within the range of cycles of the Earth's orbital parameters that are thought to be the main forcing mechanism of global climate change. However, local influences of current winnowing and productivity have altered any primary climatic signal of orbital forcing at both Lord Howe Rise and Ontong-Java Plateau.

\section{ACKNOWLEDGMENTS}

We thank the shipboard scientific parties of Legs 89 and 90 for their help in sampling the cores and for providing physical property, carbonate, and biostratigraphic data. We appreciate the helpful reviews of this manuscript by M. T. Ledbetter and J. P. Kennett. This work was supported by the U.S. Geological Survey Climate Program.

\section{REFERENCES}

Anderson, J. B., 1972. The marine geology of the Weddell Sea. Florida State Univ. Sediment. Res. Lab., Contrib., 35.

Andrews, J. E., Packham, G. H., et al., 1975. Init. Repts. DSDP, 30: Washington (U.S. Govt. Printing Office).

Backman, J., 1979. Pliocene biostratigraphy of DSDP Sites 111 and 116 from the North Atlantic Ocean and the age of Northern Hemisphere glaciation. Stockholm Contrib. Geol., 32(3):115-137.

Berger, W. H., Bonneau, M.-C., and Parker, F. L., 1982. Foraminifera on the deep-sea floor: Lysocline and dissolution rate. Oceanol. Ac$t a, 5: 249-258$.

Berger, W. H., Ekdale, A. A., and Bryant, P. P., 1979. Selective preservation of burrows in deep-sea carbonates. Mar. Geol., 32:205-230.

Berger, W. H., and Johnson, T. C., 1976. Deep-sea carbonates: Dissolution and mass wasting on Ontong-Java Plateau. Science, 192: 785-787.

Berger, W. H., Johnson, T. C., and Hamilton, E. L., 1977. Sedimentation on Ontong-Java Plateau: Observations on a classic "carbonate monitor." In Anderson, N. R., and Malahoff, A. (Eds.), The Fate of Fossil Fuel $\mathrm{CO}_{2}$ in the Oceans: New York (Plenum Publ. Corp.), pp. 543-567.

Berggren, W. A., 1972. Late Pliocene-Pleistocene glaciation. In Laughton, A. S., Berggren, W. A., et al., Init. Repts. DSDP, 12: Washington (U.S. Govt. Printing Office), 953-963.

Bonneau, M.-C., Vergnaud Grazzini, C., and Berger, W. H., 1980. Stable isotope fractionation and differential dissolution in recent planktonic foraminifera from Pacific box-cores. Oceanol. Acta, 3: 377-382.

Burns, R. E., Andrews, J. E., 1973. Init. Repts. DSDP, 21: Washington (U.S. Govt. Printing Office).

Ciesielski, P. F., Ledbetter, M. T., and Ellwood, B. B., 1982. The development of Antarctic glaciation and the Neogene paleoenvironment of the Maurice Ewing Bank. Mar. Geol., 46:1-51.

Davies, J. C., 1973. Statistics and Data Analysis in Geology: New York (John Wiley and Sons, Inc.).

Davies, T. A., and Worsley, T. R., 1981. Paleoenvironmental implications of oceanic carbonate sedimentation rates. In Warme, J. E.,
Douglas, R. G., and Winterer, E. L. (Eds.), The Deep Sea Drilling Project: A Decade of Progress. Soc. Econ. Paleont. Mineral. Spec. Publ., 32:169-179.

Dean, W. E., Gardner, J. V., and Čepek, P., 1981. Tertiary carbonatedissolution cycles on the Sierra Leone Rise, Eastern Equatorial Atlantic Ocean. Mar. Geol., 39:81-101.

Ellis, H., 1981. Calcareous nannoplankton biostratigraphy-(Deep Sea Drilling Project) Leg 60. In Hussong, D. M., Uyeda, S., et al., Init. Repts. DSDP, 60: Washington (U.S. Govt. Printing Office), 507-535.

Fleck, R. J., Mercer, J. H., Nairn, A. E. M., and Peterson, D. N., 1972. Chronology of late Pliocene and early Pleistocene glacial and magnetic events in Southern Argentina. Earth Planet. Sci. Lett., 16:15-22.

Gardner, J. V., 1975. Late Pleistocene carbonate dissolution cycles in the eastern equatorial Atlantic. In Sliter, W. V., Bé, A. W. H., and Berger, W. H. (Eds.), Dissolution of Deep-Sea Carbonates. Cushman Found. Foram. Res., Spec. Publ., 13:129-141.

Hayes, D. E., Frakes, L. A., et al., 1975. Init. Repts. DSDP, 28: Washington (U.S. Govt. Printing Office).

Hays, J. D., Imbrie, J., and Shackleton, N. J., 1976. Variations in the Earth's orbit: Pacemaker of the Ice Ages. Science, 194:1121-1132.

Holdsworth, B. K., 1975. Cenozoic Radiolaria biostratigraphy; Leg 30: Tropical and equatorial Pacific. In Andrews, J. E., Packham, G. H., et al., Init. Repts. DSDP, 30: Washington (U.S. Govt. Printing Office), 499-537.

Huffman, E. W. D., 1977. Performance o a new automatic carbon dioxide coulometer. Microchem. J., 22:567-573.

Johnson, T. C., Hamilton, E. L., and Berger, W. H., 1977. Physical properties of calcareous ooze: Control by dissolution at depth. Mar. Geol., 24:259-277.

Keany, J., 1978. Paleoclimatic trends in early and middle Pliocene deep-sea sediments of the Antarctic. Mar. Micropaleontol., 3:35-49.

Kennett, J. P., 1977. Cenozoic evolution of Antarctic glaciation, the Circum-Antarctic Ocean, and their impact on global paleoceanography. J. Geophys. Res., 82:3843-3860.

1982. Marine Geology: Englewood Cliffs, N. J., (PrenticeHall, Inc).

1983. Paleo-oceanography: Global ocean evolution. In James, D. E. (Ed.), Reviews of Geophysics and Space Physics, 21 : $1258-1274$

Kent, D., Opdyke, N. D., and Ewing, M., 1971. Climatic change in the North Pacific using ice-rafted detritus as a climatic indicator. Geol. Soc. Am. Bull., 82:2741-2754.

Klein, G. deV., 1975. Depositional facies of Leg 30 Deep Sea Drilling Project sediment cores. In Andrews, J. E., Packham, G. H., et al., Init. Repts. DSDP, 30: Washington (U.S. Govt. Printing Office), 423-442.

Krishnamurthy, R. V., Lal, D., Somayajulu, B. L. K., and Berger, W. H., 1979. Radiometric studies of box cores from the Ontong-Java Plateau. Proc. Indian Acad. Sci., 88A:273-283.

Ledbetter, M. T., and Ellwood, B. B., 1976. Selection of sample intervals in deep-sea sedimentary cores. Geology, 4:303-304.

Ledbetter, M. T., Williams, D. F., and Ellwood, B. B., 1978. Late Pliocene climate and southwest Atlantic abyssal circulation. Nature, 272:237-239.

Mercer, J. H., 1976. Glacial history of southernmost South America. Quat. Res., 6:125-166.

Moberly, R., Schlanger, S. O., et al., in press. Init. Repts. DSDP, 89: Washington (U.S. Govt. Printing Office).

Müller, G., and Gastner, M., 1971. The "Karbonate bomb," a simple device for the determination of carbonate content in sediment, soils, and other materials. N. Jahrb. Mineral. Mh., 10:466-469.

Okada, H., and Bukry, D., 1980. Supplementary modifications and introduction of code numbers to the low-latitude coccolith biostratigraphic zonation (Bukry, 1973; 1975). Mar. Micropaleontol., $5: 321-325$.

Pisias, N. G., and Moore, T. C., 1981. The evolution of Pleistocene climate: A time series approach. Earth Planet. Sci. Lett., 52: 450-458.

Poore, R, Z., 1981. Temporal and spartial distribution of ice-rafted mineral grains in Pliocene sediments of the North Atlantic: Implications for Late Cenozoic climatic history. Soc. Econ. Paleont. Mineral. Spec. Publ., 32:505-515. 
Shackleton, N. J., and Kennett, J. P., 1975. Late Cenozoic oxygen and carbon isotope changes at Deep Sea Drilling Project Site 284: Implications for glacial history of the Northern Hemisphere and Antarctica. In Kennett, J. P., Houtz, R. E., et al., Init. Repts. DSDP, 29: Washington (U.S. Govt. Printing Office), 801-807.

Shackleton, N. J., and Opdyke, N. D., 1973. Oxygen isotope and paleomagnetic stratigraphy of equatorial Pacific core V28-238: Oxygen isotope temperatures on a $10^{5}$ and $10^{6}$ year time scale. Quat. Res., 3:39-55.

1976. Oxygen-isotope and paleomagnetic stratigraphy of Pacific core V28-239 late Pliocene to latest Pleistocene. Geol. Soc. Am. Mem., 145:449-464.

, 1977. Oxygen isotope and paleomagnetic evidence for early Northern Hemisphere glaciation. Nature, 270:216-219.

Thiede, J., 1977. Textural variations of calcareous coarse fractions in the Panama Basin (Eastern Equatorial Pacific Ocean). In Anderson, N. R., and Malahoff, A. (Eds.), The Fate of Fossil Fuel $\mathrm{CO}_{2}$ in the Oceans: New York (Plenum Publ. Corp.), pp. 673-692.

Thompson, P. R., and Saito, T., 1974. Pacific Pleistocene sediments: Planktonic Foraminifera dissolution cycles and geochronology. Geology, 2:333-335.

Thompson, P. R., and Sciarrillo, J. R., 1978. Planktonic foraminiferal biostratigraphy in the Equatorial Pacific. Nature, 275:29-33. van Andel, Tj. H., Heath, G. R., and Moore, T. C., 1977. Cenozoic history and paleoceanography of the central equatorial Pacific Ocean. Geol. Soc. Am. Mem., 143.

van der Lingen, G. J., and Packham, G. H., 1975. Relationships between diagenesis and physical properties of biogenic sediments of the Ontong-Java Plateau (Sites 288 and 289; Deep Sea Drilling Project). In Andrews, J. E., Packham, G. H., et al., Init. Repts. DSDP, 30: Washington (U.S. Govt. Printing Office), 443-481.

Vincent E., Killingley, J. S., and Berger, W. H., 1981. Stable isotope composition of benthic foraminifera from the equatorial Pacific. Nature, 289:639-643.

Woodruff, F., Savin, S. M., and Douglas, R. G., 1981. Miocene stable isotope record: A detailed deep Pacific Ocean study and its paleoclimatic implications. Science, 212:665-668.

Worsley, T. R., and Davies, T. A., 1979. Cenozoic sedimentation in the Pacific Ocean: Steps toward a quantitative evaluation. J. Sediment. Petrol., 49:1131-1146.

Date of Initial Receipt: 5 October 1984 Date of Acceptance: 5 April 1985 
APPENDIX A

Coarse- and Fine-Fraction Percentages, Sites 586 and 591

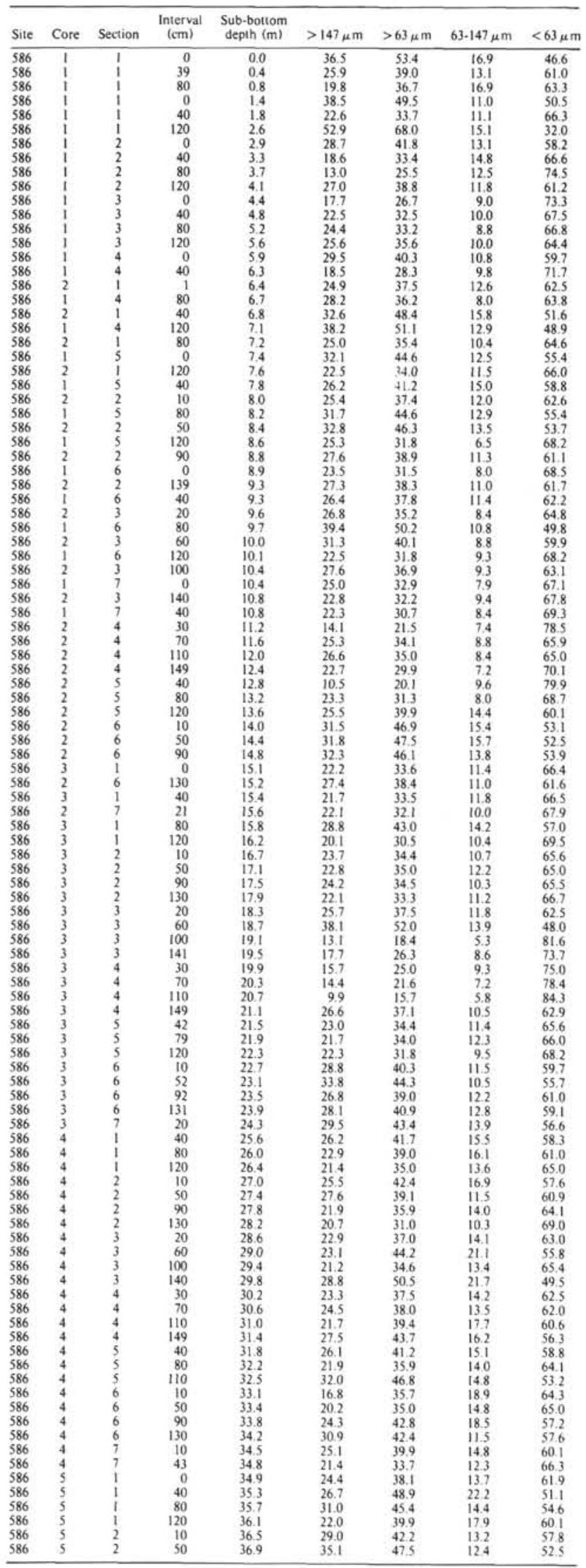

Appendix A. (Continued).

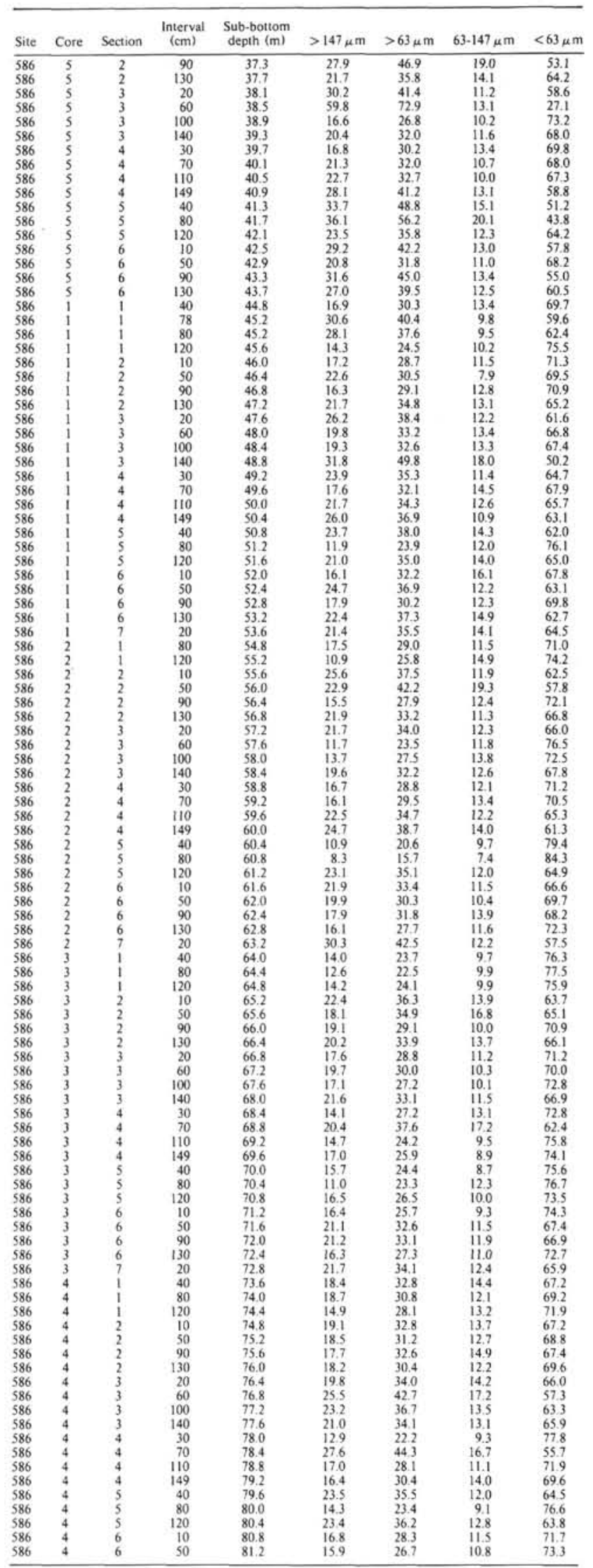


Appendix A. (Continued).

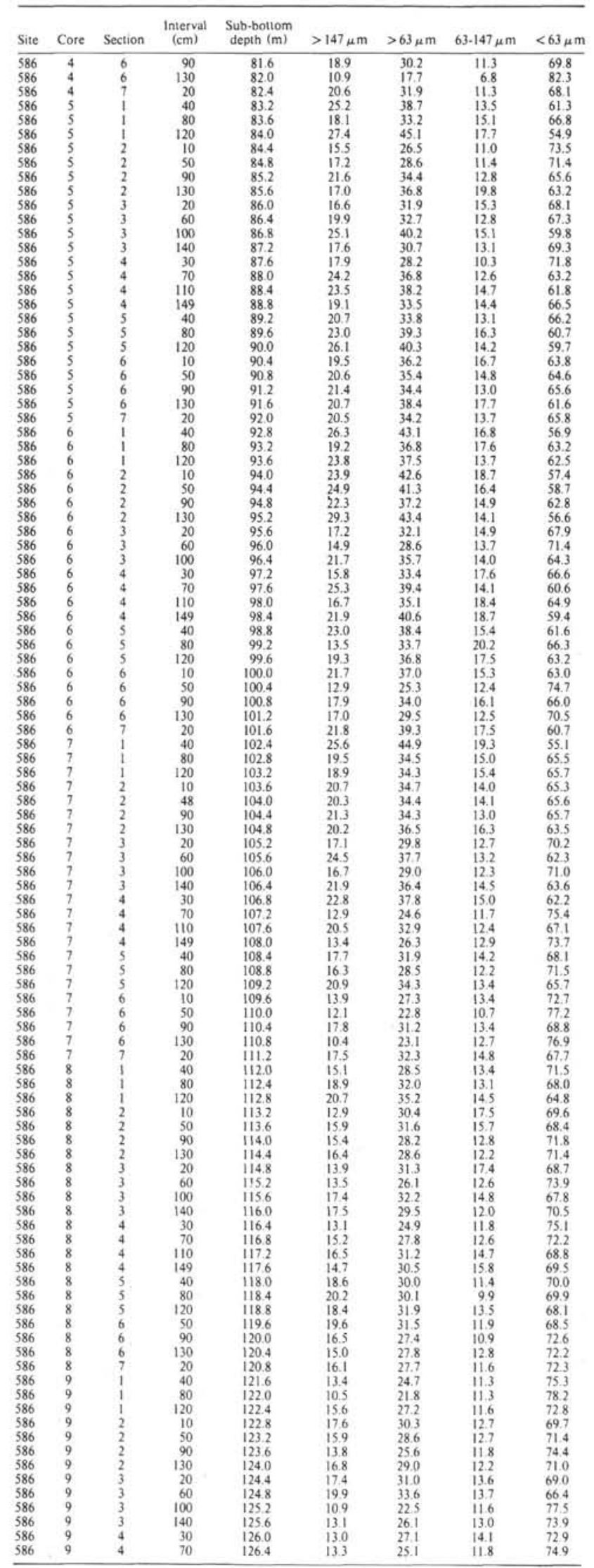

Appendix A. (Continued).

\begin{tabular}{|c|c|c|c|}
\hline Site & Core & Section & $\begin{array}{c}\begin{array}{c}\text { Interval } \\
(\mathrm{cm})\end{array} \\
\text { (a) }\end{array}$ \\
\hline $\begin{array}{l}586 \\
586\end{array}$ & 9 & 4 & 110 \\
\hline $\begin{array}{l}586 \\
586\end{array}$ & 9 & 4 & 149 \\
\hline & 9 & 5 & 40 \\
\hline $\begin{array}{l}586 \\
586\end{array}$ & $\stackrel{9}{9}$ & 5 & $\begin{array}{r}80 \\
120\end{array}$ \\
\hline 586 & 9 & 6 & $\begin{array}{r}120 \\
10\end{array}$ \\
\hline 586 & 9 & 6 & 50 \\
\hline 586 & 9 & 6 & 90 \\
\hline $\begin{array}{c}586 \\
{ }_{586}\end{array}$ & 9 & 6 & 130 \\
\hline $\begin{array}{l}586 \\
586\end{array}$ & 10 & $?$ & $\begin{array}{l}20 \\
40\end{array}$ \\
\hline 586 & 10 & & $\begin{array}{l}40 \\
80\end{array}$ \\
\hline 586 & 10 & & 120 \\
\hline 586 & 10 & 2 & 10 \\
\hline $\begin{array}{l}586 \\
586\end{array}$ & 10 & 2 & 50 \\
\hline $\begin{array}{l}586 \\
586\end{array}$ & $\begin{array}{l}10 \\
10\end{array}$ & ${ }_{2}^{2}$ & $\begin{array}{r}90 \\
130\end{array}$ \\
\hline $\begin{array}{l}580 \\
586\end{array}$ & 100 & & $\begin{array}{r}130 \\
20\end{array}$ \\
\hline 586 & 10 & 3 & $\begin{array}{l}20 \\
60\end{array}$ \\
\hline 586 & 10 & 3 & 100 \\
\hline 586 & 10 & 3 & 140 \\
\hline 586 & 10 & 4 & 30 \\
\hline 586 & 10 & 4 & 70 \\
\hline 586 & 10 & 4 & 110 \\
\hline $\begin{array}{l}586 \\
586\end{array}$ & ${ }_{10}^{10}$ & $\begin{array}{l}4 \\
5\end{array}$ & $\begin{array}{r}149 \\
40\end{array}$ \\
\hline $\begin{array}{l}580 \\
586\end{array}$ & $\begin{array}{l}10 \\
10\end{array}$ & $\begin{array}{l}5 \\
5\end{array}$ & $\begin{array}{l}40 \\
80\end{array}$ \\
\hline 586 & 10 & 5 & 120 \\
\hline 586 & 10 & 6 & 10 \\
\hline & 10 & 6 & \\
\hline 586 & 10 & 6 & 130 \\
\hline 586 & & & 20 \\
\hline 586 & 11 & 1 & 40 \\
\hline $\begin{array}{l}586 \\
586\end{array}$ & 11 & 1 & 80 \\
\hline $\begin{array}{l}586 \\
586\end{array}$ & II & $\frac{1}{2}$ & $\begin{array}{r}120 \\
10\end{array}$ \\
\hline $\begin{array}{l}586 \\
586\end{array}$ & II & ${ }_{2}^{2}$ & $\begin{array}{l}10 \\
50\end{array}$ \\
\hline 586 & ii & 2 & 90 \\
\hline 586 & 11 & 2 & 130 \\
\hline & 11 & 3 & 20 \\
\hline 586 & II & 3 & 60 \\
\hline 586 & 11 & & 100 \\
\hline 586 & 11 & 3 & 140 \\
\hline $\begin{array}{l}586 \\
586\end{array}$ & II & 4 & $\begin{array}{l}30 \\
70\end{array}$ \\
\hline $\begin{array}{l}586 \\
586\end{array}$ & II & 4 & $\begin{array}{r}70 \\
110\end{array}$ \\
\hline $\begin{array}{l}586 \\
586\end{array}$ & II & $\begin{array}{l}4 \\
4\end{array}$ & $\begin{array}{l}140 \\
149\end{array}$ \\
\hline 586 & ii & 5 & 40 \\
\hline 586 & ii & 5 & 80 \\
\hline & ii & 5 & 120 \\
\hline 586 & $i i$ & 6 & 10 \\
\hline 586 & ii & 6 & 130 \\
\hline 586 & 11 & 6 & 50 \\
\hline 586 & 11 & 7 & 20 \\
\hline $\begin{array}{l}586 \\
586\end{array}$ & (1) & ${ }^{6}$ & $\begin{array}{l}90 \\
40\end{array}$ \\
\hline $\begin{array}{l}580 \\
586\end{array}$ & 12 & i & $\begin{array}{l}40 \\
80\end{array}$ \\
\hline 586 & 12 & 1 & 120 \\
\hline 586 & 12 & 2 & 10 \\
\hline 586 & 12 & 2 & 50 \\
\hline & 12 & 2 & 90 \\
\hline 58 & 12 & 2 & 130 \\
\hline 586 & 12 & 3 & 20 \\
\hline $\begin{array}{l}586 \\
586\end{array}$ & 12 & 3 & 60 \\
\hline $\begin{array}{c}586 \\
586\end{array}$ & 12 & 3 & 140 \\
\hline $\begin{array}{l}586 \\
586\end{array}$ & 12 & 4 & 30 \\
\hline 586 & 12 & 4 & 70 \\
\hline 586 & 12 & 4 & 110 \\
\hline 58 & 12 & 4 & 149 \\
\hline 58 & 12 & 5 & 40 \\
\hline 586 & 12 & 5 & 80 \\
\hline 586 & 12 & 6 & 10 \\
\hline $\begin{array}{l}586 \\
586\end{array}$ & 12 & 6 & 50 \\
\hline $\begin{array}{c}58 \\
58 \\
\end{array}$ & 12 & 6 & $\begin{array}{l}90 \\
130\end{array}$ \\
\hline $\begin{array}{l}586 \\
586\end{array}$ & 12 & 6 & $\begin{array}{r}130 \\
20\end{array}$ \\
\hline 586 & 13 & 1 & $\begin{array}{l}20 \\
40\end{array}$ \\
\hline 586 & 13 & $\mathrm{i}$ & 80 \\
\hline 58 & 13 & $i$ & 120 \\
\hline 58 & 13 & 2 & 10 \\
\hline 58 & 13 & 2 & so \\
\hline 586 & 13 & 2 & 90 \\
\hline 58 & 13 & 2 & $\begin{array}{l}130 \\
30\end{array}$ \\
\hline 58 & 13 & 3 & $\begin{array}{l}20 \\
60\end{array}$ \\
\hline $\begin{array}{l}380 \\
586\end{array}$ & 13 & 3 & $\begin{array}{l}60 \\
100\end{array}$ \\
\hline 58 & 13 & 3 & $\begin{array}{l}100 \\
140\end{array}$ \\
\hline 586 & 13 & 4 & 30 \\
\hline 586 & 13 & 4 & 70 \\
\hline 58 & 13 & 4 & 110 \\
\hline 58 & 13 & 4 & 149 \\
\hline 586 & 13 & 5 & 40 \\
\hline 586 & 13 & 3 & 80 \\
\hline $\begin{array}{l}586 \\
586\end{array}$ & 14 & i & $\begin{array}{l}40 \\
80\end{array}$ \\
\hline 58 & 4 & 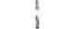 & $\begin{array}{r}80 \\
120\end{array}$ \\
\hline $\begin{array}{r}380 \\
680\end{array}$ & 14 & 2 & $\begin{array}{r}220 \\
10\end{array}$ \\
\hline 586 & 14 & & ${ }_{50}$ \\
\hline 586 & 14 & & 90 \\
\hline 586 & 14 & 2 & 130 \\
\hline 586 & 14 & 3 & 20 \\
\hline 586 & 14 & 3 & 60 \\
\hline 586 & 14 & 3 & $\begin{array}{l}100 \\
140\end{array}$ \\
\hline $\begin{array}{l}586 \\
586\end{array}$ & $\begin{array}{l}14 \\
15\end{array}$ & ${ }_{1}^{3}$ & $\begin{array}{r}140 \\
40\end{array}$ \\
\hline
\end{tabular}


COARSE-FRACTION AND CARBONATE STRATIGRAPHIES

Appendix A. (Continued).

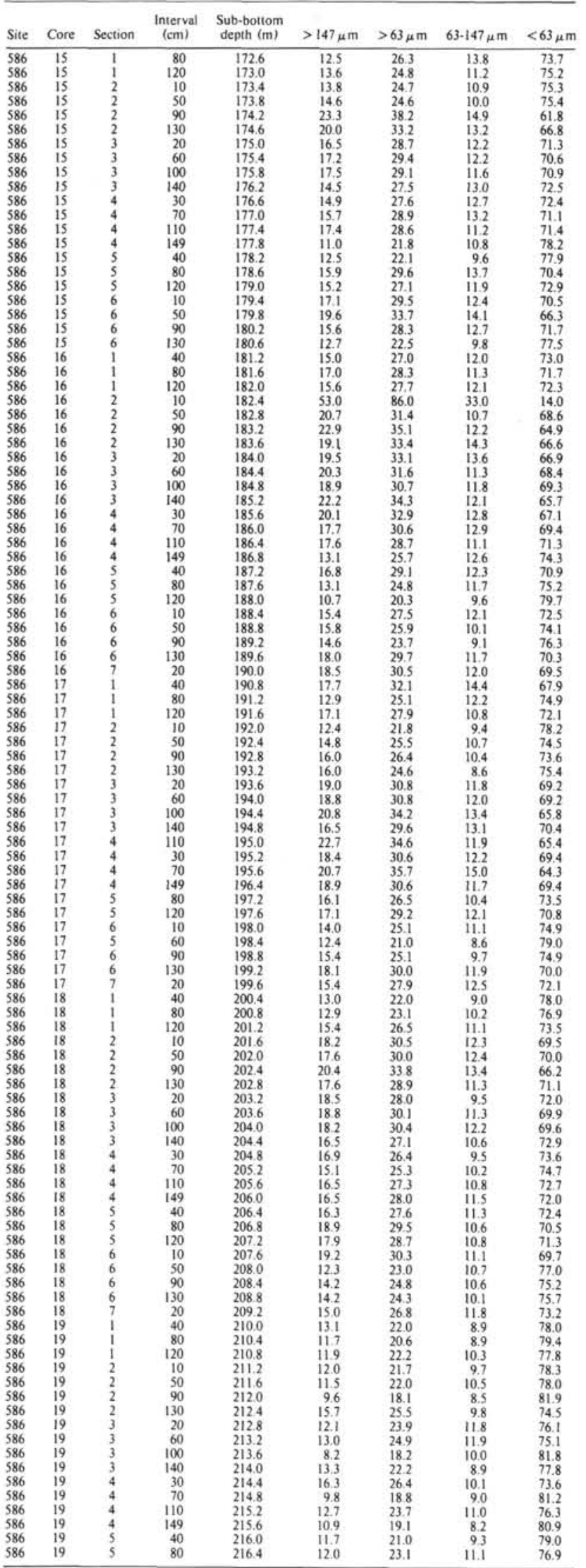

Appendix A. (Continued).

\begin{tabular}{|c|c|c|c|}
\hline Site & Core & Section & $\begin{array}{l}\text { Interval } \\
(\mathrm{cm})\end{array}$ \\
\hline 586 & 19 & 5 & 120 \\
\hline .586 & 19 & & 10 \\
\hline 586 & 19 & 6 & 50 \\
\hline $\begin{array}{l}586 \\
586\end{array}$ & 20 & 1 & $\begin{array}{l}40 \\
80\end{array}$ \\
\hline $\begin{array}{l}586 \\
586\end{array}$ & $\begin{array}{l}20 \\
20\end{array}$ & i & $\begin{array}{r}80 \\
120\end{array}$ \\
\hline 586 & 20 & $\frac{1}{2}$ & $\begin{array}{r}120 \\
10\end{array}$ \\
\hline 586 & 20 & 2 & 50 \\
\hline 586 & 20 & 2 & 90 \\
\hline 586 & 20 & 2 & 130 \\
\hline $\begin{array}{l}586 \\
586\end{array}$ & 20 & 3 & 20 \\
\hline $\begin{array}{l}586 \\
586\end{array}$ & 20 & 3 & 60 \\
\hline $\begin{array}{l}580 \\
586\end{array}$ & 20 & 3 & $\begin{array}{l}100 \\
140\end{array}$ \\
\hline 586 & 20 & 4 & $\begin{array}{r}400 \\
30\end{array}$ \\
\hline 586 & 20 & 4 & 70 \\
\hline 586 & 20 & 4 & 110 \\
\hline 586 & 20 & 4 & 149 \\
\hline 586 & 20 & 5 & 40 \\
\hline 586 & 20 & 5 & 80 \\
\hline $\begin{array}{c}586 \\
68\end{array}$ & 20 & 5 & 120 \\
\hline $\begin{array}{l}586 \\
586\end{array}$ & $\begin{array}{l}20 \\
20\end{array}$ & $\begin{array}{l}6 \\
6\end{array}$ & $\begin{array}{l}10 \\
50\end{array}$ \\
\hline 586 & $\begin{array}{l}20 \\
20\end{array}$ & $\begin{array}{l}6 \\
6\end{array}$ & $\begin{array}{l}50 \\
90\end{array}$ \\
\hline 586 & 20 & 6 & 130 \\
\hline 586 & 21 & 2 & 10 \\
\hline 586 & 21 & 2 & 50 \\
\hline 586 & 21 & 2 & 90 \\
\hline 586 & 21 & 2 & 130 \\
\hline 586 & 21 & 3 & 20 \\
\hline 586 & 21 & 3 & 60 \\
\hline $\begin{array}{l}386 \\
688\end{array}$ & 21 & 3 & 100 \\
\hline $\begin{array}{l}380 \\
586\end{array}$ & 21 & 4 & $\begin{array}{l}140 \\
30\end{array}$ \\
\hline 586 & 21 & 4 & $\begin{array}{l}30 \\
70\end{array}$ \\
\hline 586 & 21 & 4 & 110 \\
\hline 586 & 21 & 4 & 149 \\
\hline 586 & 21 & 5 & 40 \\
\hline 586 & 21 & 5 & 80 \\
\hline $\begin{array}{l}586 \\
586\end{array}$ & 21 & $\begin{array}{l}5 \\
6\end{array}$ & $\begin{array}{l}120 \\
10\end{array}$ \\
\hline $\begin{array}{l}586 \\
586\end{array}$ & $\begin{array}{l}21 \\
21\end{array}$ & $\begin{array}{l}6 \\
6\end{array}$ & $\begin{array}{l}10 \\
50\end{array}$ \\
\hline 586 & 21 & 6 & 90 \\
\hline 586 & 21 & 6 & 130 \\
\hline 586 & 21 & 7 & 20 \\
\hline 586 & 21 & ? & 20 \\
\hline 586 & 21 & $?$ & 60 \\
\hline 586 & 21 & $?$ & 100 \\
\hline 586 & 22 & ! & 40 \\
\hline 586 & 21 & $?$ & $\begin{array}{l}140 \\
80\end{array}$ \\
\hline 586 & 22 & 8 & $\begin{array}{l}80 \\
30\end{array}$ \\
\hline 586 & 21 & $i$ & 120 \\
\hline 586 & 22 & 2 & 10 \\
\hline 586 & 22 & 2 & 50 \\
\hline 586 & 22 & 2 & 90 \\
\hline 586 & 22 & 2 & 130 \\
\hline 586 & 22 & 3 & 20 \\
\hline 586 & 22 & $3^{3}$ & 60 \\
\hline 586 & 22 & $3^{3}$ & 100 \\
\hline $\begin{array}{l}586 \\
586\end{array}$ & 22 & 4 & $\begin{array}{r}140 \\
30\end{array}$ \\
\hline 586 & 2 & 4 & 70 \\
\hline 586 & 22 & 4 & 110 \\
\hline 586 & 22 & 4 & 149 \\
\hline 586 & 22 & 5 & 40 \\
\hline 586 & 22 & 5 & 80 \\
\hline 586 & 22 & 5 & 120 \\
\hline 586 & 22 & 6 & 10 \\
\hline 586 & ${ }^{22} 2$ & 6 & 50 \\
\hline $\begin{array}{l}586 \\
586\end{array}$ & 22 & 6 & $\begin{array}{l}90 \\
130\end{array}$ \\
\hline 586 & $\frac{22}{22}$ & 7 & $\begin{array}{r}130 \\
20\end{array}$ \\
\hline 586 & 23 & $i$ & 40 \\
\hline 586 & 23 & i & 80 \\
\hline 586 & 23 & $i$ & 120 \\
\hline 586 & 23 & 2 & 10 \\
\hline 586 & 23 & 2 & 50 \\
\hline 586 & 23 & 2 & 90 \\
\hline $\begin{array}{l}586 \\
586\end{array}$ & 23 & 2 & 130 \\
\hline $\begin{array}{l}586 \\
586\end{array}$ & 23 & 3 & 20 \\
\hline 586 & 23 & 3 & 100 \\
\hline 586 & 23 & 3 & 140 \\
\hline 586 & 23 & 4 & ${ }_{70}^{30}$ \\
\hline $\begin{array}{l}586 \\
586\end{array}$ & 23 & 4 & 70 \\
\hline 586 & 23 & ${ }_{4}^{4}$ & 149 \\
\hline 586 & 23 & 5 & 40 \\
\hline 586 & 23 & 5 & 80 \\
\hline 586 & 23 & $s$ & 120 \\
\hline 586 & 23 & 6 & 10 \\
\hline 586 & 23 & 6 & 50 \\
\hline 586 & 23 & 6 & 90 \\
\hline 586 & 23 & 6 & 130 \\
\hline $\begin{array}{c}586 \\
68\end{array}$ & 23 & ) & 20 \\
\hline 586 & 24 & i & 80 \\
\hline 586 & & & 120 \\
\hline 586 & 24 & & 10 \\
\hline & 24 & & 50 \\
\hline & 24 & 2 & 90 \\
\hline 586 & 24 & 2 & 130 \\
\hline 586 & 24 & 3 & 20 \\
\hline $\begin{array}{l}586 \\
586\end{array}$ & $\begin{array}{l}24 \\
24\end{array}$ & ${ }_{3}^{3}$ & $\begin{array}{r}60 \\
100\end{array}$ \\
\hline
\end{tabular}


Appendix A. (Continued).

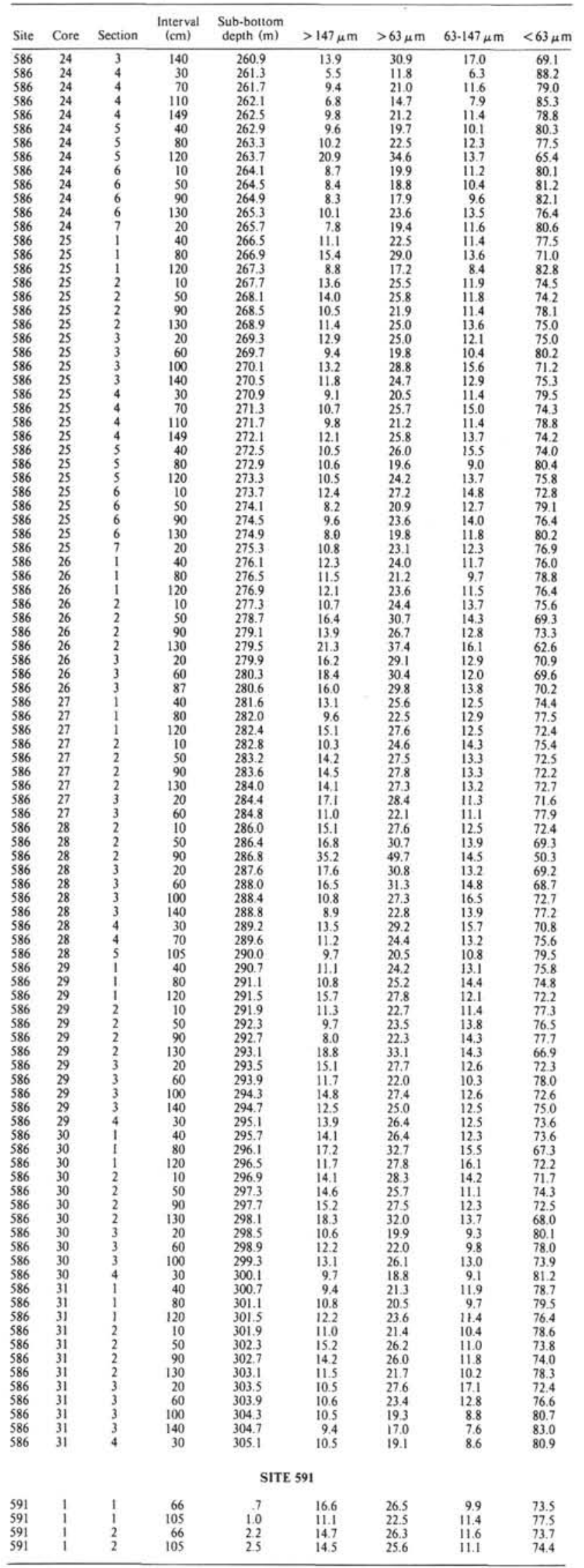

Appendix A. (Continued).

\begin{tabular}{|c|c|c|c|}
\hline Site & Core & Section & $\begin{array}{c}\text { Interval } \\
(\mathrm{cm})\end{array}$ \\
\hline 591 & 2 & 1 & $\overline{40}$ \\
\hline & 2 & i & 105 \\
\hline 591 & 2 & 2 & 40 \\
\hline $\begin{array}{l}591 \\
591\end{array}$ & 2 & 2 & $\begin{array}{l}105 \\
40\end{array}$ \\
\hline $\begin{array}{l}591 \\
591\end{array}$ & $\frac{2}{2}$ & $\begin{array}{l}3 \\
4\end{array}$ & $\begin{array}{l}40 \\
40\end{array}$ \\
\hline 591 & 2 & 4 & 105 \\
\hline 591 & 2 & 5 & 40 \\
\hline 591 & 2 & 5 & 105 \\
\hline $\begin{array}{l}591 \\
599\end{array}$ & 2 & 6 & 40 \\
\hline $\begin{array}{l}591 \\
591\end{array}$ & $\frac{2}{3}$ & ${ }_{1}^{6}$ & $\begin{array}{r}105 \\
40\end{array}$ \\
\hline 591 & $\frac{3}{3}$ & 1 & $\begin{array}{l}40 \\
105\end{array}$ \\
\hline 591 & 3 & 2 & 40 \\
\hline 591 & 3 & 2 & 105 \\
\hline 591 & 3 & 3 & 40 \\
\hline 591 & 3 & 3 & 105 \\
\hline 591 & & 4 & 40 \\
\hline 591 & 3 & 4 & 105 \\
\hline $\begin{array}{l}591 \\
591\end{array}$ & 3 & 5 & 40 \\
\hline 591 & $\begin{array}{l}3 \\
3\end{array}$ & 6 & $\begin{array}{l}105 \\
40\end{array}$ \\
\hline 591 & 3 & $\begin{array}{l}6 \\
6\end{array}$ & $\begin{array}{l}40 \\
105\end{array}$ \\
\hline 591 & 4 & 1 & 105 \\
\hline 591 & 4 & 2 & $\begin{array}{r}40 \\
\end{array}$ \\
\hline $\begin{array}{l}591 \\
591\end{array}$ & 4 & 2 & $\begin{array}{r}105 \\
40\end{array}$ \\
\hline $\begin{array}{l}591 \\
591\end{array}$ & $\begin{array}{l}4 \\
4\end{array}$ & ${ }_{3}^{3}$ & $\begin{array}{r}40 \\
105\end{array}$ \\
\hline 591 & $\begin{array}{l}4 \\
4\end{array}$ & 4 & $\begin{array}{r}105 \\
40\end{array}$ \\
\hline 591 & 4 & 4 & 105 \\
\hline 591 & 4 & 5 & 40 \\
\hline 591 & 4 & 5 & 105 \\
\hline 591 & 4 & 6 & 40 \\
\hline 591 & 4 & 6 & 105 \\
\hline 591 & 5 & 1 & 40 \\
\hline 591 & 5 & 1 & 105 \\
\hline $\begin{array}{l}591 \\
591\end{array}$ & 5 & 2 & $\begin{array}{r}40 \\
105\end{array}$ \\
\hline 591 & $\begin{array}{l}5 \\
5\end{array}$ & ${ }_{3}^{2}$ & $\begin{array}{r}105 \\
40\end{array}$ \\
\hline 591 & 5 & 3 & 105 \\
\hline 591 & 5 & 4 & 40 \\
\hline 591 & 5 & 4 & 105 \\
\hline $59 !$ & 5 & s & 40 \\
\hline 591 & 5 & 5 & 105 \\
\hline 591 & 5 & 6 & 40 \\
\hline 591 & 6 & 1 & 110 \\
\hline 591 & 6 & 2 & 110 \\
\hline $\begin{array}{l}391 \\
591\end{array}$ & 6 & 3 & $\begin{array}{l}110 \\
110\end{array}$ \\
\hline 591 & 6 & 5 & 110 \\
\hline 591 & 6 & 6 & 110 \\
\hline 591 & 7 & 1 & 40 \\
\hline $\begin{array}{l}591 \\
591\end{array}$ & 7 & $\frac{1}{2}$ & 105 \\
\hline $\begin{array}{l}591 \\
591\end{array}$ & 7 & $\frac{2}{2}$ & $\begin{array}{r}40 \\
105\end{array}$ \\
\hline 591 & 7 & $\frac{2}{3}$ & 40 \\
\hline 591 & 7 & 3 & 105 \\
\hline $\begin{array}{l}591 \\
591\end{array}$ & 7 & 4 & 40 \\
\hline $\begin{array}{l}591 \\
591\end{array}$ & $?$ & 4 & 105 \\
\hline 591 & 7 & ${ }_{5}^{3}$ & $\begin{array}{r}40 \\
105\end{array}$ \\
\hline 591 & 7 & 6 & 40 \\
\hline 591 & 7 & 6 & 105 \\
\hline 591 & 8 & 1 & 40 \\
\hline 591 & 8 & i & 105 \\
\hline 591 & 8 & 2 & 40 \\
\hline 591 & 8 & 2 & 105 \\
\hline 591 & 8 & 3 & 40 \\
\hline 591 & 8 & 4 & $\begin{array}{r}105 \\
40\end{array}$ \\
\hline $\begin{array}{l}391 \\
591\end{array}$ & 8 & $\begin{array}{l}4 \\
4\end{array}$ & $\begin{array}{l}40 \\
105\end{array}$ \\
\hline 591 & 8 & 5 & $\begin{array}{l}105 \\
40\end{array}$ \\
\hline 591 & 8 & 5 & 105 \\
\hline 591 & 8 & 6 & $\begin{array}{r}40 \\
105\end{array}$ \\
\hline $\begin{array}{l}591 \\
591\end{array}$ & 8 & 6 & \\
\hline $\begin{array}{r}591 \\
591\end{array}$ & 9 & $\frac{1}{2}$ & $\begin{array}{r}110 \\
40\end{array}$ \\
\hline 591 & 9 & 2 & 110 \\
\hline 591 & 9 & 3 & 40 \\
\hline 591 & 9 & 3 & 110 \\
\hline $\begin{array}{l}391 \\
591\end{array}$ & 9 & $\begin{array}{l}4 \\
4\end{array}$ & 40 \\
\hline $\begin{array}{l}591 \\
591\end{array}$ & g. & 5 & 1110 \\
\hline 591 & 9 & 5 & 110 \\
\hline 591 & 9 & 6 & 40 \\
\hline 591 & 9 & 6 & 110 \\
\hline 591 & 10 & 1 & 110 \\
\hline 591 & 10 & 2 & 40 \\
\hline 591 & 10 & 2 & 110 \\
\hline 591 & 10 & 3 & $\begin{array}{l}40 \\
110\end{array}$ \\
\hline S91 & 100 & 4 & $\begin{array}{r}110 \\
40\end{array}$ \\
\hline 591 & $\begin{array}{l}10 \\
10\end{array}$ & 4 & $\begin{array}{l}400 \\
110\end{array}$ \\
\hline 591 & 10 & 5 & 40 \\
\hline 591 & 10 & 5 & 110 \\
\hline $\begin{array}{l}391 \\
591\end{array}$ & $\begin{array}{l}10 \\
10\end{array}$ & $\begin{array}{l}6 \\
6\end{array}$ & $\begin{array}{r}40 \\
110\end{array}$ \\
\hline 591 & II & 1 & 110 \\
\hline 591 & 11 & 2 & 40 \\
\hline 591 & 11 & 2 & 110 \\
\hline $\begin{array}{l}591 \\
591\end{array}$ & II & ${ }_{3}^{3}$ & $\begin{array}{r}40 \\
110\end{array}$ \\
\hline $\begin{array}{l}591 \\
591\end{array}$ & iI & 4 & 40 \\
\hline 591 & 11 & 4 & 110 \\
\hline 591 & ii & 5 & 40 \\
\hline 591 & & 5 & 110 \\
\hline .591 & II & 6 & 40 \\
\hline 591 & 11 & 6 & 110 \\
\hline
\end{tabular}


Appendix A. (Continued).

\begin{tabular}{|c|c|c|c|c|}
\hline Site & Core & Section & $\begin{array}{c}\text { Interval } \\
(\mathrm{cm})\end{array}$ & $\begin{array}{l}\text { Sub-bottom } \\
\text { depth }(\mathrm{m})\end{array}$ \\
\hline 591 & 12 & 1 & 110 & 100.5 \\
\hline 591 & 12 & 2 & 40 & 101.3 \\
\hline 591 & 12 & 2 & 110 & 102.0 \\
\hline & 12 & 3 & 40 & 102.8 \\
\hline $\begin{array}{l}591 \\
591\end{array}$ & 12 & 3 & $\begin{array}{r}110 \\
40\end{array}$ & $\begin{array}{l}103.5 \\
0.543\end{array}$ \\
\hline $\begin{array}{l}5911 \\
591\end{array}$ & $\frac{12}{12}$ & 4 & $\begin{array}{l}40 \\
110\end{array}$ & $\begin{array}{l}104.3 \\
1050\end{array}$ \\
\hline 591 & 12 & 5 & 40 & 105.8 \\
\hline 591 & 12 & 5 & 110 & 106.5 \\
\hline $\begin{array}{l}591 \\
591\end{array}$ & 12 & 6 & 40 & $\begin{array}{l}107.3 \\
1080\end{array}$ \\
\hline 591 & 13 & $i$ & 40 & $\begin{array}{l}108.0 \\
1094\end{array}$ \\
\hline 591 & 13 & 1 & 110 & 110.1 \\
\hline 591 & 13 & 2 & 40 & 110.9 \\
\hline 591 & 13 & 2 & 70 & 111.2 \\
\hline $\begin{array}{l}591 \\
591\end{array}$ & 13 & 2 & $\begin{array}{l}110 \\
40\end{array}$ & 111.6 \\
\hline 591 & $\begin{array}{l}13 \\
13\end{array}$ & 3 & $\begin{array}{l}40 \\
110\end{array}$ & $\begin{array}{l}1124 \\
1131\end{array}$ \\
\hline 591 & 13 & 4 & 40 & 113.9 \\
\hline 591 & 13 & 5 & 110 & 114.6 \\
\hline $\begin{array}{l}591 \\
5991\end{array}$ & 13 & 5 & 40 & 115.4 \\
\hline $\begin{array}{l}591 \\
591\end{array}$ & ${ }_{13}^{13}$ & $\begin{array}{l}5 \\
6\end{array}$ & $\begin{array}{r}110 \\
40\end{array}$ & $\begin{array}{l}116.1 \\
1169\end{array}$ \\
\hline S91 & $\begin{array}{l}13 \\
13\end{array}$ & $\begin{array}{l}6 \\
6\end{array}$ & $\begin{array}{l}40 \\
110\end{array}$ & $\begin{array}{l}116.9 \\
117.6\end{array}$ \\
\hline 591 & 13 & 7 & 70 & 118.7 \\
\hline 591 & 14 & 1 & 40 & 118.7 \\
\hline 591 & 14 & 1 & 110 & 119.4 \\
\hline 591 & $\begin{array}{l}14 \\
14\end{array}$ & $\frac{2}{2}$ & $\begin{array}{l}40 \\
70\end{array}$ & $\begin{array}{l}120.2 \\
1205\end{array}$ \\
\hline 591 & 14 & 2 & 110 & 120.9 \\
\hline 591 & 14 & 3 & 40 & 121.7 \\
\hline $\begin{array}{l}591 \\
591\end{array}$ & ${ }_{14}^{14}$ & 3 & 110 & 122.4 \\
\hline (591 & $\begin{array}{l}14 \\
14\end{array}$ & ${ }_{4}^{4}$ & $\begin{array}{r}40 \\
110\end{array}$ & $\begin{array}{l}123.2 \\
1239\end{array}$ \\
\hline 591 & 14 & 5 & 40 & 124.7 \\
\hline 591 & 14 & 5 & 70 & 125.0 \\
\hline 591 & 14 & 5 & 110 & 125.4 \\
\hline 591 & $\begin{array}{l}14 \\
14\end{array}$ & $\begin{array}{l}6 \\
6\end{array}$ & $\begin{array}{r}40 \\
40\end{array}$ & $\begin{array}{l}126.2 \\
1269\end{array}$ \\
\hline 591 & $\begin{array}{l}144 \\
14\end{array}$ & 7 & 40 & $\begin{array}{l}128.7 \\
127.7\end{array}$ \\
\hline 591 & is & i & 40 & 128.0 \\
\hline $59 !$ & 15 & 1 & 110 & 128.7 \\
\hline $\begin{array}{l}591 \\
591\end{array}$ & 15 & 2 & $\begin{array}{l}40 \\
70\end{array}$ & $\begin{array}{l}129.5 \\
1298\end{array}$ \\
\hline 591 & is & 2 & 110 & $\begin{array}{r}1298 \\
1302\end{array}$ \\
\hline 591 & is & 3 & 40 & 1310 \\
\hline 591 & is & 3 & 110 & 131.7 \\
\hline 591 & is & 4 & 40 & 1325 \\
\hline 591 & 15 & 4 & 110 & 1332 \\
\hline 591 & 15 & 5 & 40 & 134.0 \\
\hline 591 & 15 & 5 & 70 & 134.3 \\
\hline 591 & 15 & 5 & 110 & 134.7 \\
\hline 591 & 15 & 6 & 40 & 135.5 \\
\hline S191 & 15 & ${ }_{1}^{6}$ & 110 & $\begin{array}{l}136.2 \\
31373\end{array}$ \\
\hline & 16 & i & 110 & $\begin{array}{l}387 \\
1380\end{array}$ \\
\hline 591 & 16 & 2 & 40 & $\begin{array}{l}138.0 \\
138 .\end{array}$ \\
\hline 591 & 16 & 2 & 110 & 1395 \\
\hline 591 & 16 & 3 & 40 & 1403 \\
\hline 591 & 16 & 3 & 110 & 1410 \\
\hline 591 & 16 & 4 & 40 & 1418 \\
\hline 591 & 16 & 4 & 110 & 142.5 \\
\hline 591 & 16 & 5 & 40 & 143.3 \\
\hline 391 & 16 & $\frac{5}{6}$ & 110 & 1440 \\
\hline 591 & 10 & 6 & 40 & $\begin{array}{l}1448 \\
1456\end{array}$ \\
\hline 591 & 17 & $i$ & 40 & 1466 \\
\hline 591 & 17 & i & 110 & $\begin{array}{l}140.6 \\
147.3\end{array}$ \\
\hline 591 & 17 & 2 & 40 & 148.1 \\
\hline 591 & i7 & 2 & 110 & 148.8 \\
\hline 591 & 17 & 3 & 40 & 149.6 \\
\hline 591 & 17 & 3 & 110 & 150.3 \\
\hline 591 & 17 & 4 & 40 & 151.1 \\
\hline 591 & 17 & 4 & 110 & 151.8 \\
\hline 591 & 17 & $s_{5}$ & 40 & 152.6 \\
\hline (391 & 1 & 8 & 110 & 534 \\
\hline 591 & 17 & 6 & 110 & 1548 \\
\hline 591 & 17 & 7 & 40 & 155.6 \\
\hline 591 & 18 & i & 40 & \\
\hline 591 & 18 & i & 110 & 156.6 \\
\hline 591 & 18 & 2 & 40 & 157.4 \\
\hline 591 & 18 & 2 & 110 & 158 \\
\hline 591 & 18 & 3 & 40 & 158 \\
\hline 591 & 18 & 3 & 110 & 1596 \\
\hline 391 & 18 & 4 & 40 & 160.4 \\
\hline (3) & 18 & 4 & 110 & 160 \\
\hline 591 & 18 & $\varsigma$ & 110 & \\
\hline 591 & $\begin{array}{l}18 \\
18\end{array}$ & 6 & 40 & $\begin{array}{l}102.8 \\
163.4\end{array}$ \\
\hline 591 & 18 & 6 & 110 & \\
\hline 591 & 19 & 1 & 40 & 165.2 \\
\hline 591 & 19 & 1 & 110 & 165.9 \\
\hline 591 & 19 & 2 & 40 & \\
\hline 591 & 19 & 2 & 110 & \\
\hline 591 & 19 & ${ }_{3}^{3}$ & 40 & $\begin{array}{l}168.2 \\
168.9\end{array}$ \\
\hline (391 & 19 & 3 & 110 & \\
\hline ६91 & 9 & 4 & 100 & \\
\hline 591 & 7 & 5 & 40 & 1712 \\
\hline 591 & 19 & 5 & 110 & 171.9 \\
\hline 591 & 19 & 6 & 40 & \\
\hline 591 & 19 & 6 & 110 & 173.4 \\
\hline 591 & 20 & 1 & 40 & 174.7 \\
\hline 591 & 20 & 1 & 110 & 175.4 \\
\hline 591 & 20 & 2 & 40 & 176.2 \\
\hline
\end{tabular}

Appendix A. (Continued).

\begin{tabular}{|c|c|c|c|c|}
\hline Site & Core & Section & $\begin{array}{c}\text { Interval } \\
(\mathrm{cm})\end{array}$ & $\begin{array}{c}\begin{array}{c}\text { Sub-bottom } \\
\text { depth }(m)\end{array} \\
\end{array}$ \\
\hline 591 & 20 & 2 & 110 & 176.9 \\
\hline 591 & 20 & 3 & 40 & 177.7 \\
\hline 591 & 20 & 3 & 110 & 178.4 \\
\hline $\begin{array}{l}591 \\
591\end{array}$ & $\begin{array}{l}20 \\
20\end{array}$ & 4 & 40 & $\begin{array}{l}179.2 \\
179.9\end{array}$ \\
\hline 591 & $\begin{array}{l}20 \\
20\end{array}$ & $\begin{array}{l}4 \\
5\end{array}$ & $\begin{array}{r}110 \\
40\end{array}$ & $\begin{array}{l}179.9 \\
180.7\end{array}$ \\
\hline 591 & 20 & 5 & 110 & 181.4 \\
\hline 591 & 20 & 6 & 40 & 182.2 \\
\hline $\begin{array}{l}591 \\
591\end{array}$ & 20 & 6 & $\begin{array}{l}110 \\
40\end{array}$ & $\begin{array}{l}182.9 \\
1842\end{array}$ \\
\hline & $\begin{array}{l}21 \\
21\end{array}$ & 1 & $\begin{array}{l}40 \\
40\end{array}$ & $\begin{array}{l}184.2 \\
184.2\end{array}$ \\
\hline 591 & ${ }_{21}^{21}$ & 1 & $\begin{array}{l}40 \\
110\end{array}$ & $\begin{array}{l}184.9 \\
1849\end{array}$ \\
\hline 591 & 21 & 1 & 110 & 184.9 \\
\hline 591 & 21 & 2 & 40 & 185.7 \\
\hline $\begin{array}{l}591 \\
591\end{array}$ & 21 & ${ }_{3}^{2}$ & $\begin{array}{l}110 \\
40\end{array}$ & $\begin{array}{l}186.4 \\
1872\end{array}$ \\
\hline 591 & 21 & ${ }_{3}^{3}$ & 110 & $\begin{array}{l}187.2 \\
187.9\end{array}$ \\
\hline 591 & 21 & 4 & 40 & 188.9 \\
\hline 591 & 21 & 4 & 110 & 189.4 \\
\hline $\begin{array}{l}591 \\
591\end{array}$ & 21 & 5 & 40 & 190.2 \\
\hline $\begin{array}{l}591 \\
591\end{array}$ & 21 & 5 & $\begin{array}{l}110 \\
40\end{array}$ & 190.9 \\
\hline 591 & 21 & $\begin{array}{l}6 \\
6\end{array}$ & 110 & 192.4 \\
\hline 591 & 22 & 2 & 40 & 1952 \\
\hline 591 & 22 & 2 & 110 & 1955 \\
\hline 591 & 22 & 3 & 40 & 196.7 \\
\hline 591 & 22 & 3 & 110 & 197.4 \\
\hline 591 & 22 & 4 & 40 & 198.2 \\
\hline 591 & 22 & 4 & 110 & 198.9 \\
\hline 591 & 22 & 5 & 40 & 199.7 \\
\hline $\begin{array}{l}591 \\
591\end{array}$ & 22 & 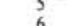 & ${ }_{40}$ & 200.4 \\
\hline 591 & 23 & $i$ & 40 & 2031 \\
\hline 591 & 23 & 1 & 110 & 203.8 \\
\hline 591 & 23 & 2 & 40 & 204.6 \\
\hline 591 & 23 & 2 & 110 & 205.3 \\
\hline $\begin{array}{l}591 \\
591\end{array}$ & 23 & 3 & 40 & 206.1 \\
\hline $\begin{array}{l}591 \\
591\end{array}$ & 23 & 3 & 110 & 206.8 \\
\hline $\begin{array}{l}391 \\
591\end{array}$ & 23 & 4 & 40 & $\begin{array}{r}207.6 \\
2083\end{array}$ \\
\hline 591 & ${ }_{23}^{23}$ & $\begin{array}{l}4 \\
5\end{array}$ & 110 & 208.3 \\
\hline 591 & 23 & 5 & 40 & $\begin{array}{l}209.1 \\
2098\end{array}$ \\
\hline 591 & 23 & 6 & 40 & 210.6 \\
\hline 591 & 23 & 6 & 110 & 211.3 \\
\hline 591 & 24 & 1 & 40 & 212.5 \\
\hline 591 & 24 & 1 & 110 & $\begin{aligned} 213.2 \\
2140\end{aligned}$ \\
\hline $\begin{array}{l}591 \\
591\end{array}$ & 24 & 2 & $\begin{array}{l}40 \\
70\end{array}$ & $\begin{array}{r}214.0 \\
214.3\end{array}$ \\
\hline $\begin{array}{l}591 \\
591\end{array}$ & $\begin{array}{l}24 \\
24\end{array}$ & 2 & 70 & $\begin{array}{l}214.3 \\
2147\end{array}$ \\
\hline 591 & 24 & 3 & 40 & 215.5 \\
\hline 591 & 24 & 3 & 110 & 216.2 \\
\hline 591 & 24 & 4 & 40 & $\begin{array}{r}217.0 \\
\end{array}$ \\
\hline $\begin{array}{l}591 \\
591\end{array}$ & 24 & ${ }_{5}^{4}$ & $\begin{array}{r}110 \\
40\end{array}$ & $\begin{array}{l}2177.7 \\
2185\end{array}$ \\
\hline 591 & $\begin{array}{l}24 \\
24\end{array}$ & $\begin{array}{l}5 \\
5\end{array}$ & $\begin{array}{l}40 \\
70\end{array}$ & $\begin{array}{l}218.5 \\
2188\end{array}$ \\
\hline 591 & 24 & 5 & 110 & 219.2 \\
\hline 591 & 24 & 6 & 40 & 220.0 \\
\hline 591 & 25 & 1 & 40 & 221.9 \\
\hline $\begin{array}{l}591 \\
591\end{array}$ & 25 & , & $\begin{array}{r}110 \\
40\end{array}$ & $\begin{array}{l}222.6 \\
7230\end{array}$ \\
\hline 591 & 25 & $\frac{2}{2}$ & 110 & $\begin{aligned} 223.4 \\
324 .\end{aligned}$ \\
\hline 591 & 25 & 3 & 40 & 224.1. \\
\hline 591 & 25 & 3 & 110 & $\begin{array}{l}224.9 \\
2256\end{array}$ \\
\hline 591 & 25 & 4 & 40 & 226.4 \\
\hline 591 & 25 & 4 & 110 & 227.1 \\
\hline 591 & 25 & 5 & 40 & 227.9 \\
\hline 591 & 25 & 5 & 110 & 228.6 \\
\hline 591 & 25 & 6 & 40 & 229.4 \\
\hline & $\begin{array}{l}25 \\
25\end{array}$ & ${ }^{6}$ & $\begin{array}{r}110 \\
40\end{array}$ & $\begin{array}{l}230.1 \\
231.5\end{array}$ \\
\hline 591 & $\begin{array}{l}26 \\
26\end{array}$ & 1 & $\begin{array}{r}40 \\
110\end{array}$ & 2322 \\
\hline 591 & $\begin{array}{l}26 \\
26\end{array}$ & 2 & 40 & 233.0 \\
\hline 591 & 26 & 2 & 110 & 233.7 \\
\hline 591 & 26 & 3 & 40 & 234.5 \\
\hline 591 & 26 & 3 & 110 & 235.3 \\
\hline 591 & 26 & 4 & 40 & 2360 \\
\hline 591 & 26 & 4 & 110 & 236.7 \\
\hline 591 & ${ }^{26}$ & 5 & 40 & 237.5 \\
\hline 591 & 27 & 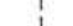 & 40 & $\begin{aligned} 241.1 \\
2418\end{aligned}$ \\
\hline 50 & 21 & 2 & 40 & 24286 \\
\hline 591 & 27 & 2 & 110 & 2433 \\
\hline 591 & 27 & 3 & 40 & 244.1 \\
\hline 591 & 27 & 3 & 110 & 244.8 \\
\hline 591 & 27 & 4 & 40 & 245.6 \\
\hline $59 !$ & 27 & 4 & 110 & 246.3 \\
\hline 591 & 27 & 5 & 40 & 247.1 \\
\hline 591 & 27 & 5 & 110 & 247.8 \\
\hline 591 & $\begin{array}{l}27 \\
37\end{array}$ & 6 & 40 & $\begin{array}{l}248.6 \\
2493\end{array}$ \\
\hline 591 & $\begin{array}{l}27 \\
28\end{array}$ & 1 & 40 & 2507 \\
\hline 591 & $\begin{array}{l}28 \\
28\end{array}$ & $i$ & 110 & 251.4 \\
\hline 591 & 28 & 2 & 40 & 252.2 \\
\hline 591 & 28 & 2 & 110 & 2529 \\
\hline 591 & $\begin{array}{l}28 \\
28\end{array}$ & 3 & 40 & $\begin{array}{l}253.7 \\
544\end{array}$ \\
\hline $\begin{array}{l}591 \\
591\end{array}$ & $\begin{array}{l}28 \\
28\end{array}$ & 3 & $\begin{array}{l}110 \\
40\end{array}$ & $\begin{array}{l}254.4 \\
3552\end{array}$ \\
\hline 591 & $\begin{array}{l}28 \\
28\end{array}$ & 4 & $\begin{array}{l}40 \\
110\end{array}$ & 255.9 \\
\hline 591 & $\begin{array}{l}28 \\
28\end{array}$ & 5 & 40 & 256.7 \\
\hline 591 & 28 & 5 & 110 & 257.4 \\
\hline 591 & 28 & 6 & 40 & 258.2 \\
\hline 591 & 28 & 6 & 110 & 258.9 \\
\hline 591 & 29 & 1 & 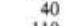 & 260.2 \\
\hline 591 & 29 & 1 & 110 & 260.7 \\
\hline 591 & 29 & 2 & 40 & 2667 \\
\hline 391 & 29 & 2 & 110 & 2624 \\
\hline
\end{tabular}


Appendix A. (Continued).

\begin{tabular}{|c|c|c|c|c|c|c|c|c|}
\hline Site & Core & Section & $\begin{array}{c}\begin{array}{c}\text { Interval } \\
(\mathrm{cm})\end{array} \\
\end{array}$ & $\begin{array}{l}\text { Sub-bottom } \\
\text { depth (m) }\end{array}$ & $>147 \mu \mathrm{m}$ & $>63 \mu \mathrm{m}$ & $63.147 \mu \mathrm{m}$ & $<63 \mu \mathrm{m}$ \\
\hline 591 & 29 & 3 & & 263.2 & 0 & 3.5 & 3.5 & 96.5 \\
\hline 591 & 29 & 3 & 110 & 263.9 & 0 & 2.9 & 29 & 97.1 \\
\hline 591 & 29 & 4 & 40 & 2647 & 0 & 3.6 & 3.6 & 96.4 \\
\hline 591 & 29 & 4 & 110 & 265.4 & 0 & 3.9 & 3.9 & 96.1 \\
\hline 591 & 29 & $\begin{array}{l}5 \\
5\end{array}$ & 40 & $\begin{array}{l}266.2 \\
2669\end{array}$ & 0 & 3.9 & 3.9 & 96.1 \\
\hline 591 & $\begin{array}{l}29 \\
29\end{array}$ & $\begin{array}{l}5 \\
6\end{array}$ & $\begin{array}{r}110 \\
40\end{array}$ & 26699 &.$_{0}^{0}$ & $\begin{array}{l}4.4 \\
5.2\end{array}$ & $\begin{array}{l}4.4 \\
552\end{array}$ & $\begin{array}{l}95.6 \\
94.8\end{array}$ \\
\hline 591 & 29 & 6 & 110 & 268.4 & .0 & 5.2 & 5.2 & $\begin{array}{l}94.8 \\
94.8\end{array}$ \\
\hline 591 & 30 & 1 & 40 & 269.7 & .0 & 5.5 & 5.5 & 94.5 \\
\hline 591 & 30 & 1 & 110 & 270.4 & 0 & $? .1$ & $\begin{array}{l}7.1 \\
57\end{array}$ & 92.9 \\
\hline 591 & $\frac{1}{30}$ & $\frac{1}{2}$ & $\begin{array}{l}36 \\
40\end{array}$ & $\begin{array}{l}271.0 \\
27.12\end{array}$ & .0 & $\begin{array}{l}5.7 \\
44\end{array}$ & $\begin{array}{l}5.7 \\
44 .\end{array}$ & $\begin{array}{l}94.3 \\
9966\end{array}$ \\
\hline 591 & 1 & 1 & 110 & $\begin{array}{l}271.2 \\
271.7\end{array}$ & 0 & $\begin{array}{l}4.4 \\
64\end{array}$ & $\begin{array}{l}4.4 \\
64\end{array}$ & $\begin{array}{l}95.6 \\
93.6\end{array}$ \\
\hline 591 & 30 & $\frac{1}{2}$ & 110 & 271.9 & 0 & $\begin{array}{l}6.4 \\
6.0\end{array}$ & $\begin{array}{l}6.4 \\
6.0\end{array}$ & $\begin{array}{l}93.0 \\
94.0\end{array}$ \\
\hline 591 & & & 36 & 2725 & 0 & 98 & 98 & 902 \\
\hline 591 & 30 & 3 & 40 & 272.7 & 0 & 4.9 & 4.9 & 95.1 \\
\hline 591 & & 2 & 110 & 273.2 & 0 & 4.9 & 4.9 & 95.1 \\
\hline 591 & 30 & 3 & 110 & 273.4 & 0 & 6.3 & 63 & 93.7 \\
\hline 591 & ' & 3 & 36 & 274.0 & 0 & 8.5 & 8.5 & 91.5 \\
\hline 591 & 31 & 1 & 40 & 274.7 & 0 & 5.5 & 5.5 & 94.5 \\
\hline 591 & 31 & 1 & $\begin{array}{l}110 \\
40\end{array}$ & $\begin{array}{l}275.4 \\
276.2\end{array}$ & 0 & 6.8 & 6.8 & $\begin{array}{l}93.2 \\
93.5\end{array}$ \\
\hline $\begin{array}{l}591 \\
591\end{array}$ & ${ }_{31}^{31}$ & $\frac{2}{2}$ & $\begin{array}{r}40 \\
110\end{array}$ & $\begin{array}{l}276.2 \\
2769\end{array}$ & ${ }_{0}^{0}$ & $\begin{array}{l}6.5 \\
5.2\end{array}$ & $\begin{array}{l}6.5 \\
52\end{array}$ & $\begin{array}{l}93.5 \\
94.8\end{array}$ \\
\hline 591 & 31 & 3 & 40 & $\begin{array}{l}276.9 \\
277.7\end{array}$ & 0 & $\begin{array}{l}3.2 \\
8.9\end{array}$ & 8.9 & $\begin{array}{l}94.8 \\
91.1\end{array}$ \\
\hline 591 & 31 & 3 & 110 & 278.4 & .0 & 7.2 & 7.2 & 92.8 \\
\hline 591 & 31 & 4 & 40 & & 0 & 8.0 & & 92.0 \\
\hline 591 & $3 i$ & 4 & 110 & 279.9 & 0 & 7.4 & 7.4 & 92.6 \\
\hline 591 & & 1 & 36 & 280.6 & 0 & 12.6 & 12.6 & 87.4 \\
\hline 591 & 31 & 5 & 40 & 280.7 & 0 & 7.6 & 7.6 & 92.4 \\
\hline 591 & $2^{2}$ & 1 & 110 & 281.3 & 0 & 8.1 & 8.1 & 91.9 \\
\hline 591 & 31 & 5 & 110 & $\begin{array}{l}281.4 \\
28.4\end{array}$ & 0 & 6.6 & 6.6 & 93.4 \\
\hline 591 & 31 & 2 & $\begin{array}{l}36 \\
40\end{array}$ & $\begin{array}{l}282.1 \\
28222\end{array}$ & 0 & 9.1 & 9.1 & 90.9 \\
\hline $\begin{array}{l}591 \\
591\end{array}$ & ${ }^{31}$ & $\begin{array}{l}6 \\
2\end{array}$ & $\begin{array}{r}40 \\
110\end{array}$ & $\begin{array}{l}2822.2 \\
2828\end{array}$ &.$_{0}^{0}$ & 7.5 & 7.5 & $\begin{array}{l}92.5 \\
92.3\end{array}$ \\
\hline 591 & $31^{2}$ & 6 & 100 & 282.9 & .0 & 6.9 & 6.9 & 93.1 \\
\hline 591 & 2 & 3 & 36 & 283.6 & 0 & 7.1 & 7.1 & 92.9 \\
\hline 591 & 2 & 3 & $\begin{array}{r}110 \\
37\end{array}$ & $\begin{array}{l}2843 \\
2902\end{array}$ & 0 & 8.3 & 8.3 & 91.7 \\
\hline $\begin{array}{l}391 \\
591\end{array}$ & 3 & 1 & $\begin{array}{l}31 \\
43\end{array}$ & $\begin{array}{l}290.2 \\
2902\end{array}$ & ${ }_{0}^{0}$ & $\begin{array}{l}7.7 \\
8.5\end{array}$ & $\begin{array}{l}7.7 \\
8.5\end{array}$ & $\begin{array}{l}92.3 \\
91.5\end{array}$ \\
\hline 591 & 3 & i & 101 & 290.8 & .0 & 7.3 & 7.3 & 92.7 \\
\hline 591 & 3 & 2 & 37 & 291.7 & 0 & 8.2 & 8.2 & 91.8 \\
\hline & & 2 & 43 & & .0 & 8.0 & 8.0 & 92.0 \\
\hline 591 & 3 & $\frac{2}{3}$ & $\begin{array}{l}101 \\
37\end{array}$ & $\begin{array}{l}292.3 \\
2932\end{array}$ & ${ }_{0}^{0}$ & $\begin{array}{l}8.5 \\
8.8\end{array}$ & $\begin{array}{l}8.5 \\
8.8\end{array}$ & $\begin{array}{l}99.5 \\
91.2\end{array}$ \\
\hline 591 & 3 & 3 & $\begin{array}{l}37 \\
47\end{array}$ & 293.3 & $\begin{array}{l}0 \\
.0\end{array}$ & $\begin{array}{l}8.8 \\
70\end{array}$ & $\begin{array}{l}8.8 \\
70\end{array}$ & $\begin{array}{l}11.2 \\
93.0\end{array}$ \\
\hline 591 & 3 & 3 & 101 & & 0 & 7.3 & 7.3 & \\
\hline 591 & 3 & 4 & 37 & 294.7 & .0 & 7.1 & 7.1 & 92 \\
\hline 591 & 3 & 4 & 43 & 294.7 & 0 & 6.9 & 6.9 & 93 \\
\hline 591 & 3 & 4 & 99 & 295.3 & 0 & 8.9 & 8.9 & \\
\hline 591 & 3 & 5 & 37 & & 0 & 8.9 & 8.9 & 91.1 \\
\hline 591 & 3 & 5 & 43 & 296.2 & 0 & 7.6 & 7.6 & 92.4 \\
\hline 591 & 3 & 5 & 105 & 296. & 0 & 9.4 & 9.4 & 90.6 \\
\hline Sal & 4 & i & 110 & $\begin{array}{l}299.8 \\
3000\end{array}$ & 0 & 13,1 & $\begin{array}{l}13.7 \\
135\end{array}$ & $\begin{array}{l}86.3 \\
86.5\end{array}$ \\
\hline 501 & 4 & 2 & 38 & 301 & 0 & 124 & 13.5 & $\begin{array}{l}865 \\
876\end{array}$ \\
\hline 591 & 4 & 2 & 110 & 302.0 & 0 & 127 & 127 & $\begin{array}{l}87.6 \\
87.3\end{array}$ \\
\hline 591 & 4 & 3 & 38 & 3028 & 0 & 152 & 15.2 & 848 \\
\hline 591 & 4 & 3 & 110 & 3035 & 0 & 106 & 10.6 & 89.4 \\
\hline 591 & 4 & 4 & 38 & 304. & 0 & 10.0 & 10.0 & 90.0 \\
\hline 591 & 4 & A & 110 & & 0 & 8.3 & 8.3 & 91,7 \\
\hline 591 & 4 & 5 & 38 & 305.8 & 0 & 8.3 & 8.3 & 91.7 \\
\hline 591 & 5 & 1 & 36 & 309.2 & 0 & 9.1 & 9.1 & 909 \\
\hline 391 & 3 & & 110 & & $\begin{array}{l}0 \\
0\end{array}$ & 8.5 & 8.5 & $\begin{array}{l}91.5 \\
900\end{array}$ \\
\hline 591 & 5 & & 100 & 314.7 & 0 & 9,9 & 57 & $\begin{array}{l}90.1 \\
943\end{array}$ \\
\hline 59 & 5 & 3 & 36 & 312 & 0 & 106 & 106 & 894 \\
\hline 591 & & 3 & 110 & & 0 & 129 & 12.9 & 87.1 \\
\hline 591 & 5 & 4 & 36 & 313.7 & 0 & 70 & 7.0 & 93.0 \\
\hline 591 & 6 & & 36 & & 0 & 12.1 & 12.1 & 87.9 \\
\hline 591 & 6 & & 110 & 319. & 0 & 10.2 & 10.2 & 89.8 \\
\hline 591 & 6 & & 36 & 320. & 0 & 11.7 & 11.7 & 88.3 \\
\hline 591 & 6 & ， & 110 & 320. & 0 & 10.2 & 10.2 & 89.8 \\
\hline 591 & 6 & 3 & 36 & 321.6 & 0 & 8.5 & 8.5 & 91.5 \\
\hline
\end{tabular}

Appendix A. (Continued).

\begin{tabular}{|c|c|c|c|c|c|c|c|c|}
\hline Site & Core & Section & $\begin{array}{c}\text { Interval } \\
(\mathrm{em})\end{array}$ & $\begin{array}{l}\text { Sub-bottom } \\
\text { depth }(\mathrm{m})\end{array}$ & $>147 \mu \mathrm{m}$ & $>63 \mu \mathrm{m}$ & $63-147 \mu \mathrm{m}$ & $<63 \mu \mathrm{m}$ \\
\hline 591 & 6 & 3 & 110 & 322.3 & 0 & 6.3 & 6.3 & 93.7 \\
\hline 591 & 6 & 4 & 36 & 323.1 & 0 & 8.2 & 8.2 & 91.8 \\
\hline 591 & $\begin{array}{l}6 \\
6\end{array}$ & ${ }_{5}^{4}$ & $\begin{array}{l}110 \\
36\end{array}$ & $\begin{array}{l}323.8 \\
3246\end{array}$ & 0 & 7.3 & $\begin{array}{l}7.3 \\
9.5\end{array}$ & $\begin{array}{l}92.7 \\
905\end{array}$ \\
\hline 591 & $\begin{array}{l}0 \\
6\end{array}$ & 5 & $\begin{array}{l}30 \\
110\end{array}$ & $\begin{array}{l}324.6 \\
325.3\end{array}$ & .0 & $\begin{array}{l}9.5 \\
8.3\end{array}$ & $\begin{array}{l}9.5 \\
8.3\end{array}$ & $\begin{array}{l}90.5 \\
91.7\end{array}$ \\
\hline 591 & 7 & i & 36 & 328.0 & .0 & 7.1 & 7.1 & $\begin{array}{l}91.7 \\
92.9\end{array}$ \\
\hline 591 & $?$ & i & 110 & 3287 & .0 & 5.9 & 5.9 & 94.1 \\
\hline 591 & 7 & 2 & 36 & $\begin{array}{l}329.5 \\
3302\end{array}$ & .0 & 12.1 & 12.1 & 87.9 \\
\hline $\begin{array}{l}591 \\
591\end{array}$ & $?$ & ${ }_{3}^{2}$ & $\begin{array}{r}110 \\
36\end{array}$ & $\begin{array}{l}330.2 \\
331.0\end{array}$ & $\begin{array}{l}.0 \\
0\end{array}$ & $\begin{array}{l}7.2 \\
5.9\end{array}$ & $\begin{array}{l}7.2 \\
59\end{array}$ & 92.8 \\
\hline 591 & 7 & 3 & 110 & 331.7 & .0 & 7.1 & 7.1 & $\begin{array}{l}94.1 \\
92.9\end{array}$ \\
\hline 591 & 7 & 4 & 36 & 332.5 & .0 & 8.7 & 8.7 & $\begin{array}{l}92.9 \\
91.3\end{array}$ \\
\hline 591 & $?$ & 4 & 110 & 333.2 & 0 & 7.3 & 7.3 & $\begin{array}{l}91.3 \\
92.7\end{array}$ \\
\hline 591 & $?$ & 5 & 36 & 334.0 & 0 & 4.1 & 4.1 & $\begin{array}{l}92.1 \\
95.9\end{array}$ \\
\hline 591 & 7 & 5 & 110 & 334.7 & .0 & 11.3 & 11.3 & 88.7 \\
\hline 591 & $?_{7}^{7}$ & 6 & 36 & 335.5 & 0 & 8.2 & 8.2 & 91.8 \\
\hline 591 & 8 & ${ }_{2}^{6}$ & $\begin{array}{r}110 \\
40\end{array}$ & $\begin{array}{l}336.2 \\
339.1\end{array}$ & $\begin{array}{l}0 \\
0\end{array}$ & $\begin{array}{l}5.9 \\
7.3\end{array}$ & 5.9 & $\begin{array}{l}94.1 \\
927\end{array}$ \\
\hline 591 & 10 & & 40 & 356.8 & .0 & 6.6 & 6.6 & $\begin{array}{l}92.7 \\
93.4\end{array}$ \\
\hline & 10 & i & 110 & 357.5 & 0 & 9.7 & 9.7 & 90.3 \\
\hline 591 & & 2 & 40 & 358.3 & 0 & 9.3 & 9.3 & 90.7 \\
\hline 591 & 10 & 2 & 110 & 359.0 & 0 & 10.6 & 10.6 & 89.4 \\
\hline 591 & 11 & 1 & 40 & 366.4 & 0 & 9.9 & 9.9 & 90.1 \\
\hline 591 & 11 & 1 & 110 & $\begin{array}{l}367.1 \\
3760\end{array}$ & .0 & 9.8 & 9.8 & 90.2 \\
\hline 591 & 12 & $\frac{1}{2}$ & $\begin{array}{l}40 \\
40\end{array}$ & $\begin{array}{l}376.0 \\
3775\end{array}$ & .0 & $\begin{array}{l}7.9 \\
59\end{array}$ & 7.9 & 92.1 \\
\hline 591 & 13 & 1 & 40 & 385.6 & 0 & $\begin{array}{l}5.9 \\
6.4\end{array}$ & 6.4 & $\begin{array}{l}94.1 \\
93.6\end{array}$ \\
\hline 591 & 13 & i & 110 & 386.3 & 0 & 6.5 & 6.5 & $\begin{array}{l}93.6 \\
93.5\end{array}$ \\
\hline 591 & 13 & 2 & 40 & 387.1 & 0 & 9.6 & 9.6 & $\begin{array}{l}93.5 \\
90.4\end{array}$ \\
\hline 591 & 13 & 2 & 110 & 387.8 & 0 & 7.7 & 7.7 & 92.3 \\
\hline $\begin{array}{l}591 \\
591\end{array}$ & $\begin{array}{l}14 \\
15\end{array}$ & i & $\begin{array}{l}40 \\
40\end{array}$ & $\begin{array}{l}395.2 \\
4048\end{array}$ & .0 & $\begin{array}{l}6.4 \\
95\end{array}$ & $\begin{array}{l}6.4 \\
9.5\end{array}$ & $\begin{array}{l}93.6 \\
90.5\end{array}$ \\
\hline 591 & is & $\mathrm{i}$ & 110 & 405.5 & 0 & 11.7 & 11.7 & $\begin{array}{l}90.5 \\
88.3\end{array}$ \\
\hline & 15 & 2 & ${ }^{40}$ & 406.3 & .0 & 21.6 & 21.6 & $\begin{array}{l}78.4 \\
80.4\end{array}$ \\
\hline 591 & 15 & 2 & 110 & $\begin{array}{l}407.0 \\
4078\end{array}$ & .0 & $\begin{array}{l}9.5 \\
79\end{array}$ & $\begin{array}{l}9.5 \\
79\end{array}$ & 90.5 \\
\hline $\begin{array}{l}591 \\
591\end{array}$ & $\begin{array}{l}15 \\
17\end{array}$ & ${ }_{1}^{3}$ & $\begin{array}{l}40 \\
40\end{array}$ & $\begin{array}{l}407.8 \\
4224 .\end{array}$ & .0 & $\begin{array}{r}7.9 \\
105\end{array}$ & $\begin{array}{r}7.9 \\
105\end{array}$ & $\begin{array}{l}92.1 \\
88.5\end{array}$ \\
\hline 591 & 17 & i & 110 & 424.7 & .0 & 11.0 & 11.0 & $\begin{array}{l}89.5 \\
89.0\end{array}$ \\
\hline 591 & 17 & 2 & 40 & & 0 & 7.9 & 7.9 & $\begin{array}{l}89.0 \\
92.1\end{array}$ \\
\hline 591 & 17 & 2 & 110 & 426.2 & .0 & 12.4 & 12.4 & $\begin{array}{l}82.1 \\
87.6\end{array}$ \\
\hline $\begin{array}{l}591 \\
591\end{array}$ & 17 & ${ }_{3}^{3}$ & 40 & $\begin{array}{l}427.0 \\
4277\end{array}$ & .0 & $\begin{array}{r}7.6 \\
140\end{array}$ & $\begin{array}{r}7.6 \\
140\end{array}$ & 92.4 \\
\hline $\begin{array}{l}391 \\
591\end{array}$ & 17 & $\begin{array}{l}3 \\
4\end{array}$ & $\begin{array}{r}110 \\
40\end{array}$ & $\begin{array}{l}4277.7 \\
428.5\end{array}$ & $\begin{array}{l}.0 \\
.0\end{array}$ & $\begin{array}{l}14.0 \\
13.4\end{array}$ & $\begin{array}{l}14.0 \\
13.4\end{array}$ & $\begin{array}{l}86.0 \\
86.6\end{array}$ \\
\hline 591 & 18 & 1 & 40 & & .0 & $\begin{array}{l}13.4 \\
10.8\end{array}$ & $\begin{array}{l}13.4 \\
10.8\end{array}$ & $\begin{array}{l}86.6 \\
89.2\end{array}$ \\
\hline 591 & 18 & 1 & 110 & 434.3 & 0 & 13.1 & 13.1 & 88.9 .2 \\
\hline 591 & 18 & 2 & 40 & $\begin{array}{l}435.1 \\
4355\end{array}$ & .0 & 9.0 & 9.0 & 91.0 \\
\hline $\begin{array}{l}591 \\
591\end{array}$ & $\begin{array}{l}18 \\
18\end{array}$ & $\frac{2}{3}$ & $\begin{array}{r}110 \\
40\end{array}$ & $\begin{array}{l}4355.8 \\
436.6\end{array}$ & $\begin{array}{l}.0 \\
0\end{array}$ & $\begin{array}{l}10.4 \\
12.8\end{array}$ & $\begin{array}{l}10.4 \\
12.8\end{array}$ & $\begin{array}{l}89.6 \\
87.2\end{array}$ \\
\hline 591 & 18 & 3 & 110 & & 0 & 12.3 & 12.3 & $\begin{array}{l}87.2 \\
87.7\end{array}$ \\
\hline & 18 & 4 & 40 & & 0 & 9.8 & 9.8 & 90.2 \\
\hline 591 & 18 & $\begin{array}{l}4 \\
5\end{array}$ & 110 & 438 & .0 & 17.2 & 17.2 & 82.8 \\
\hline 59 & $\begin{array}{l}18 \\
18\end{array}$ & 5 & 40 & & $\begin{array}{l}0 \\
0 \\
0\end{array}$ & 14.9 & 14.9 & 85.1 \\
\hline 591 & $\begin{array}{l}18 \\
18\end{array}$ & $\begin{array}{l}5 \\
6\end{array}$ & 110 & $\begin{array}{l}440.3 \\
441.1\end{array}$ & $\begin{array}{l}0 \\
0 \\
0\end{array}$ & $\begin{array}{l}16.2 \\
124\end{array}$ & 16.2 & 83.8 \\
\hline 591 & $\begin{array}{l}18 \\
18\end{array}$ & $\begin{array}{l}0 \\
6\end{array}$ & $\begin{array}{l}40 \\
110\end{array}$ & 1.8 & 0 & $\begin{array}{l}12.4 \\
11.9\end{array}$ & $\begin{array}{l}12.4 \\
119\end{array}$ & $\begin{array}{l}87.6 \\
88.1\end{array}$ \\
\hline 59 & $\begin{array}{l}10 \\
19\end{array}$ & $i$ & 40 & 3.2 & 0 & 16.5 & 16.5 & 83.5 \\
\hline 591 & 19 & $i$ & 110 & 3.9 & 0 & 31.7 & 31.7 & 68.3 \\
\hline 591 & 19 & 2 & 40 & & .0 & 15.0 & 15.0 & 85.0 \\
\hline 591 & 19 & 2 & 110 & & 0 & 12.9 & 12.9 & 87.1 \\
\hline 59 & 19 & 3 & 40 & .2 & 0 & 8.9 & 8.9 & 91.1 \\
\hline & 19 & $\begin{array}{l}4 \\
4\end{array}$ & $\begin{array}{r}40 \\
110\end{array}$ & $\begin{array}{l}447.7 \\
448.4\end{array}$ & $\begin{array}{l}0 \\
0 \\
0\end{array}$ & 177 & 7.7 & $\begin{array}{l}92.3 \\
887\end{array}$ \\
\hline 59 & 19 & $\begin{array}{l}4 \\
5\end{array}$ & 40 & & $\begin{array}{l}0 \\
0\end{array}$ & $\begin{array}{r}7.3 \\
7.1\end{array}$ & $\begin{array}{c}17.3 \\
7.1\end{array}$ & $\begin{array}{l}82.7 \\
99.9\end{array}$ \\
\hline 591 & 20 & $\hat{i}$ & 40 & & 0 & 60 & 6.0 & $\begin{array}{l}92.9 \\
94.0\end{array}$ \\
\hline 591 & 20 & i & 110 & & .0 & 13.3 & 13.3 & 86 \\
\hline 591 & 20 & 2 & 40 & $\begin{array}{l}4543 \\
4556\end{array}$ & 0 & $\begin{array}{r}5.3 \\
119\end{array}$ & $\begin{array}{r}5.3 \\
119\end{array}$ & \\
\hline 59 & 20 & ${ }_{4}^{3}$ & $\begin{array}{l}40 \\
40 \\
40\end{array}$ & $\begin{array}{l}4558.8 \\
4573\end{array}$ & $\begin{array}{l}0 \\
0 \\
0\end{array}$ & $\begin{array}{r}11.9 \\
40\end{array}$ & 11.9 & $\begin{array}{l}88.1 \\
960\end{array}$ \\
\hline 591 & 20 & $\begin{array}{l}4 \\
5\end{array}$ & $\begin{array}{l}40 \\
40\end{array}$ & $\begin{array}{l}458.3 \\
48\end{array}$ & .0 & $\begin{array}{l}4.0 \\
5.9\end{array}$ & $\begin{array}{l}4.0 \\
5.9\end{array}$ & $\begin{array}{l}96.0 \\
941\end{array}$ \\
\hline 591 & 21 & i & 40 & $\begin{array}{l}462.4 \\
460\end{array}$ & 0 & 8.6 & 8.6 & 91.4 \\
\hline 591 & 21 & 2 & 40 & 463.9 & 0 & 7.4 & 74 & \\
\hline 591 & 21 & 3 & 40 & $\begin{array}{r}465.4 \\
4725\end{array}$ & .0 & 9.9 & 99 & $\begin{array}{l}90.1 \\
805\end{array}$ \\
\hline 591 & 22 & & 40 & 472.0 & & 10.5 & & \\
\hline
\end{tabular}


APPENDIX B

Carbonate Percentages, Sites 586 and 591

\begin{tabular}{|c|c|c|c|c|c|}
\hline Hole & Core & Section & $\begin{array}{c}\text { Interval } \\
(\mathrm{cm})\end{array}$ & $\begin{array}{l}\text { Sub-bottom } \\
\text { depth }(\mathrm{m})\end{array}$ & $\% \mathrm{CaCO}_{3}$ \\
\hline $\begin{array}{l}586 \\
586\end{array}$ & 1 & $\frac{1}{3}$ & 31 & 0.79 & 84.0 \\
\hline & 2 & $\begin{array}{l}3 \\
3\end{array}$ & 110 & $\begin{array}{r}5.40 \\
14.56\end{array}$ & $\begin{array}{l}780 \\
880\end{array}$ \\
\hline & $\begin{array}{l}3 \\
4\end{array}$ & $\frac{3}{4}$ & $\begin{array}{l}76 \\
92\end{array}$ & $\begin{array}{l}14.56 \\
25.72\end{array}$ & $\begin{array}{l}88.0 \\
890\end{array}$ \\
\hline & 5 & 2 & 105 & 32.35 & 89.0 \\
\hline $586 \mathrm{~A}$ & 1 & 2 & 79 & 45.69 & 88.0 \\
\hline & ${ }_{2}^{2}$ & 1 & 75 & $\begin{array}{l}54.75 \\
5670\end{array}$ & $\begin{array}{r}88.0 \\
88.0\end{array}$ \\
\hline & $\frac{2}{3}$ & $\begin{array}{l}3 \\
2\end{array}$ & $\begin{array}{l}70 \\
69\end{array}$ & $\begin{array}{l}56.70 \\
6579\end{array}$ & $\begin{array}{l}88.0 \\
860\end{array}$ \\
\hline $586 \mathrm{~A}$ & 4 & $\frac{2}{2}$ & $\begin{array}{l}69 \\
48 \\
48\end{array}$ & $\begin{array}{l}65.18 \\
75.18\end{array}$ & $\begin{array}{l}86.0 \\
89.0\end{array}$ \\
\hline $586 \mathrm{~A}$ & 5 & 2 & 75 & & 90.0 \\
\hline & 6 & 2 & 29 & $\begin{array}{r}94.19 \\
\end{array}$ & 90.0 \\
\hline & $\begin{array}{l}7 \\
8\end{array}$ & 2 & 31 & 103.85 & $\begin{array}{l}94.0 \\
850\end{array}$ \\
\hline & $\begin{array}{l}8 \\
9\end{array}$ & $\frac{2}{2}$ & $\begin{array}{l}31 \\
27\end{array}$ & $\begin{array}{l}113.41 \\
122,97\end{array}$ & $\begin{array}{l}85.0 \\
990\end{array}$ \\
\hline $586 \mathrm{~A}$ & 10 & 2 & 30 & 132.60 & 95.0 \\
\hline & 11 & 5 & 100 & & 97.0 \\
\hline & ${ }_{13}^{12}$ & 2 & 64 & & 96.0 \\
\hline & $\begin{array}{l}13 \\
14\end{array}$ & $\frac{2}{2}$ & $\begin{array}{l}60 \\
24\end{array}$ & 16864 & $\begin{array}{l}99.0 \\
950\end{array}$ \\
\hline $586 \mathrm{~A}$ & is & 2 & 60 & & $\begin{array}{l}98.0 \\
98.0\end{array}$ \\
\hline & 16 & 2 & 70 & & 96.0 \\
\hline & 17 & 6 & 7 & & \\
\hline & 19 & & & $\begin{array}{l}202.10 \\
21300\end{array}$ & $\begin{array}{l}99.0 \\
960\end{array}$ \\
\hline & 20 & 2 & 20 & $\begin{array}{r}1130.97 \\
219.80\end{array}$ & $\begin{array}{l}950 \\
98.0\end{array}$ \\
\hline & 20 & 2 & 82 & & 93.0 \\
\hline & ${ }_{22}^{21}$ & $4^{4}$ & 108 & & \\
\hline & 23 & & & $\begin{array}{l}240.90 \\
2537\end{array}$ & $\begin{array}{l}92.0 \\
970\end{array}$ \\
\hline & 24 & 6 & 14 & & $\begin{array}{l}97,0 \\
99.0\end{array}$ \\
\hline & 25 & 6 & 137 & & \\
\hline & 26 & 3 & $\begin{array}{r}75 \\
105\end{array}$ & & \\
\hline & 21 & & 105 & & 9300 \\
\hline 586 & 29 & 3 & 99 & 294.29 & 96.0 \\
\hline $586 \mathrm{~A}$ & 30 & & 54 & 295.84 & 96.0 \\
\hline & & & & & \\
\hline
\end{tabular}

SITE 591

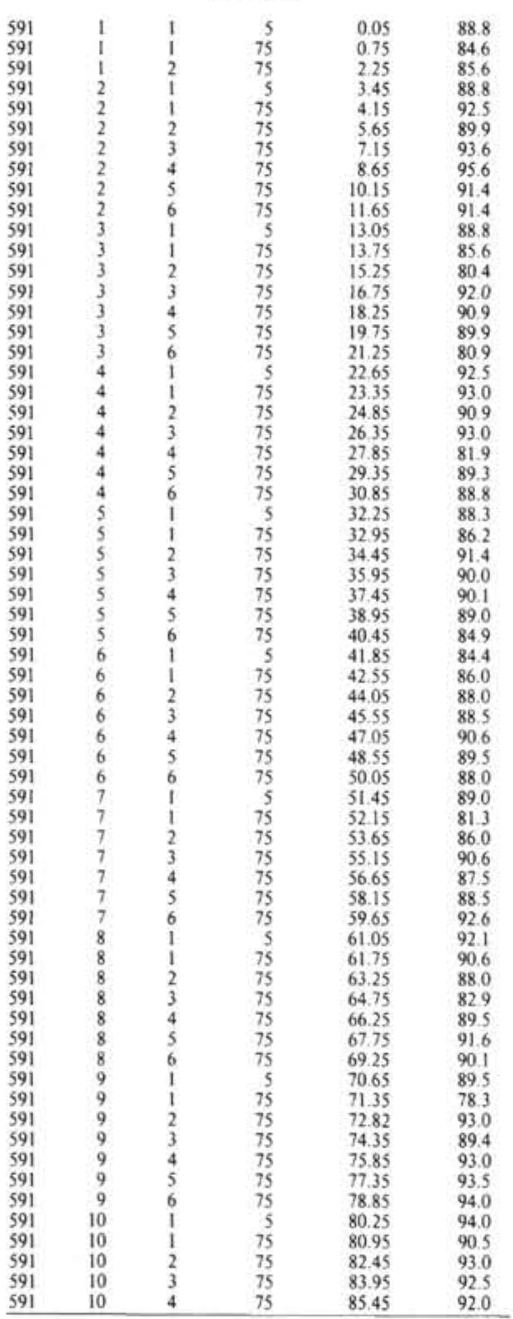

Appendix B. (Continued).

\begin{tabular}{|c|c|c|c|c|c|}
\hline Hole & Core & Section & $\begin{array}{c}\text { Interval } \\
(\mathrm{cm})\end{array}$ & $\begin{array}{l}\text { Sub-botiom } \\
\text { depth (m) }\end{array}$ & $" \mathrm{ACaCO}$, \\
\hline 591 & 10 & 5 & 75 & 86.95 & 93.0 \\
\hline 591 & 10 & 6 & 75 & 88.45 & 91.5 \\
\hline 591 & II & I & 75 & $\begin{array}{l}90.55 \\
92.05\end{array}$ & $\begin{array}{l}87.4 \\
815\end{array}$ \\
\hline 591 & II & ${ }_{3}^{2}$ & $\begin{array}{l}75 \\
75\end{array}$ & $\begin{array}{l}92.05 \\
93.55\end{array}$ & $\begin{array}{l}91.5 \\
920\end{array}$ \\
\hline $\begin{array}{l}591 \\
591\end{array}$ & II & $\begin{array}{l}3 \\
4\end{array}$ & $\begin{array}{l}75 \\
75\end{array}$ & $\begin{array}{l}9355 \\
95.05\end{array}$ & $\begin{array}{l}92.0 \\
95.1\end{array}$ \\
\hline 591 & ii & 5 & 75 & 96.55 & 92.0 \\
\hline 591 & 11 & 6 & 75 & 98.05 & 91.5 \\
\hline $59 !$ & 12 & 1 & 75 & 100.15 & $\begin{array}{l}92.5 \\
925\end{array}$ \\
\hline $\begin{array}{l}591 \\
591\end{array}$ & 12 & ${ }_{3}^{2}$ & $\begin{array}{l}75 \\
75\end{array}$ & $\begin{array}{l}101.65 \\
103.15\end{array}$ & $\begin{array}{l}92.5 \\
920\end{array}$ \\
\hline 591 & 12 & 4 & 75 & 10465 & $\begin{array}{l}92.5 \\
915\end{array}$ \\
\hline 591 & 12 & 5 & 75 & 106.15 & \\
\hline 591 & 12 & 6 & 75 & 107.65 & 91.5 \\
\hline 591 & 13 & i & 0 & 109.00 & 90.5 \\
\hline 591 & 13 & i & 75 & 109.75 & 85.4 \\
\hline 591 & 13 & 2 & 75 & 111.25 & 90.5 \\
\hline 591 & 13 & 3 & 75 & 112.75 & 91.5 \\
\hline 591 & 13 & 4 & 75 & $\begin{array}{l}114.25 \\
11575\end{array}$ & 86.9 \\
\hline $\begin{array}{l}591 \\
591\end{array}$ & ${ }_{13}^{13}$ & $\begin{array}{l}5 \\
6\end{array}$ & $\begin{array}{l}75 \\
75\end{array}$ & 115,75 & $\begin{array}{l}92.0 \\
894\end{array}$ \\
\hline $\begin{array}{l}591 \\
591\end{array}$ & $\begin{array}{l}13 \\
14\end{array}$ & $\begin{array}{l}6 \\
1\end{array}$ & $\begin{array}{l}75 \\
75\end{array}$ & $\begin{array}{l}117.25 \\
11900\end{array}$ & $\begin{array}{l}8944 \\
900\end{array}$ \\
\hline 591 & 14 & 2 & 75 & 120.55 & 87.9 \\
\hline 591 & 14 & 3 & 75 & 122.05 & 90.5 \\
\hline $59 !$ & ${ }_{14}^{14}$ & $\begin{array}{l}4 \\
5\end{array}$ & 75 & $\begin{array}{l}123.55 \\
1250\end{array}$ & $\begin{array}{l}87.4 \\
88.4\end{array}$ \\
\hline 591 & $\begin{array}{l}14 \\
14\end{array}$ & $\begin{array}{l}5 \\
6\end{array}$ & $\begin{array}{l}75 \\
75\end{array}$ & $\begin{array}{l}125.05 \\
126.55\end{array}$ & $\begin{array}{l}88.4 \\
90.0\end{array}$ \\
\hline 591 & 15 & 1 & 75 & 128.35 & 869 \\
\hline 591 & 15 & 2 & 75 & 129.85 & 89.4 \\
\hline 591 & 15 & 3 & 75 & $\begin{array}{l}131.35 \\
133.8\end{array}$ & $\begin{array}{l}88.4 \\
884\end{array}$ \\
\hline $\begin{array}{l}591 \\
591\end{array}$ & is & $\begin{array}{l}4 \\
5\end{array}$ & $\begin{array}{l}75 \\
75\end{array}$ & $\begin{array}{l}132.85 \\
134.35\end{array}$ & $\begin{array}{l}884 \\
884\end{array}$ \\
\hline 591 & is & 6 & 75 & $\begin{array}{l}135.85 \\
\end{array}$ & 91.0 \\
\hline 591 & 16 & 3 & 75 & 140.65 & 88.9 \\
\hline 591 & 16 & 4 & $\begin{array}{l}75 \\
75\end{array}$ & $\begin{array}{l}142.15 \\
143.65\end{array}$ & $\begin{array}{l}90.0 \\
905\end{array}$ \\
\hline 591 & $\begin{array}{l}16 \\
16\end{array}$ & $\begin{array}{l}5 \\
6\end{array}$ & $\begin{array}{l}75 \\
75\end{array}$ & $\begin{array}{l}43.65 \\
14515\end{array}$ & $\begin{array}{l}90.5 \\
905\end{array}$ \\
\hline $\begin{array}{l}591 \\
591\end{array}$ & $\begin{array}{l}\text { 皇 } \\
17\end{array}$ & ${ }_{2}^{6}$ & 75 & $\begin{array}{l}148.45 \\
148.13\end{array}$ & 90.5 \\
\hline 591 & 17 & 3 & 75 & 149.95 & 91.5 \\
\hline 591 & 17 & 4 & 75 & $\begin{array}{l}151.45 \\
152.95\end{array}$ & $\begin{array}{l}90.5 \\
90.5\end{array}$ \\
\hline $\begin{array}{l}591 \\
591\end{array}$ & $\begin{array}{l}17 \\
17\end{array}$ & $\begin{array}{l}5 \\
6\end{array}$ & $\begin{array}{l}75 \\
75\end{array}$ & $\begin{array}{l}152.95 \\
154.45\end{array}$ & $\begin{array}{l}90.5 \\
90.5\end{array}$ \\
\hline 591 & 18 & 1 & 75 & 156.25 & 90.0 \\
\hline 591 & 18 & 2 & 75 & 157.75 & 900 \\
\hline 591 & 18 & 3 & 75 & 159.25 & 88.4 \\
\hline $\begin{array}{l}591 \\
591\end{array}$ & 18 & $\begin{array}{l}4 \\
5\end{array}$ & $\begin{array}{l}75 \\
75\end{array}$ & $\begin{array}{l}160.75 \\
162.25\end{array}$ & $\begin{array}{l}90.0 \\
894\end{array}$ \\
\hline 591 & 18 & 6 & 75 & 163.75 & 88.4 \\
\hline 591 & 19 & 1 & 75 & 165.55 & 89.4 \\
\hline 591 & 19 & 2 & $\begin{array}{l}75 \\
75\end{array}$ & $\begin{array}{l}167.05 \\
16850\end{array}$ & $\begin{array}{l}91.5 \\
894\end{array}$ \\
\hline 591 & 19 & 3 & $\begin{array}{l}75 \\
75\end{array}$ & $\begin{array}{l}168.55 \\
177005\end{array}$ & $\begin{array}{l}89.4 \\
884\end{array}$ \\
\hline 591 & 19 & 5 & 75 & 171.55 & $\begin{array}{l}91.0 \\
91.0\end{array}$ \\
\hline 591 & 19 & 6 & 75 & 173.05 & 89.4 \\
\hline 591 & 20 & 1 & 5 & 174.35 & 88.4 \\
\hline 591 & 20 & ! & 75 & $\begin{array}{l}175.05 \\
176.55\end{array}$ & $\begin{array}{r}88.9 \\
889\end{array}$ \\
\hline 591 & 20 & 2 & 75 & $\begin{array}{l}176.55 \\
17805\end{array}$ & 88.9 \\
\hline 591 & 20 & 4 & 75 & 179.55 & 90.5 \\
\hline 591 & 20 & 5 & 75 & 181.05 & 879 \\
\hline 591 & 20 & ${ }_{1}^{6}$ & $\begin{array}{r}75 \\
5\end{array}$ & $\begin{array}{r}182.55 \\
183.85\end{array}$ & $\begin{array}{l}87.4 \\
894\end{array}$ \\
\hline 591 & 21 & i & 75 & 184.55 & 88.4 \\
\hline 591 & 21 & 2 & 75 & 186.05 & 90.5 \\
\hline $59 !$ & 21 & 3 & 75 & 187.55 & 87.4 \\
\hline 591 & 21 & 4 & 75 & 189.05 & $\begin{array}{l}89.4 \\
96.4\end{array}$ \\
\hline F91 & $\begin{array}{l}21 \\
21\end{array}$ & 6 & 75 & 192.05 & $\begin{array}{l}96.1 \\
93.4\end{array}$ \\
\hline 591 & 22 & i & 5 & 193.35 & 94.0 \\
\hline 591 & 22 & 1 & 75 & 194.05 & 94.0 \\
\hline $\begin{array}{l}591 \\
591\end{array}$ & ${ }_{22}^{22}$ & $\frac{2}{3}$ & $\begin{array}{l}75 \\
75\end{array}$ & $\begin{array}{l}195.55 \\
197.05\end{array}$ & $\begin{array}{l}94.5 \\
94.5\end{array}$ \\
\hline 591 & 22 & 4 & 75 & 198.55 & 93.4 \\
\hline 591 & 22 & 5 & 75 & 200.05 & 92.9 \\
\hline 591 & 23 & 1 & 5 & 202.75 & 91.9 \\
\hline 591 & 23 & I & $\begin{array}{l}75 \\
75\end{array}$ & $\begin{array}{r}203.45 \\
20495\end{array}$ & $\begin{array}{r}94.5 \\
990\end{array}$ \\
\hline $\begin{array}{l}591 \\
591\end{array}$ & 23 & 3 & 75 & $\begin{array}{l}204.95 \\
20645\end{array}$ & $\begin{array}{r}92.9 \\
90.8\end{array}$ \\
\hline 591 & 23 & 4 & 75 & 207.95 & 90.8 \\
\hline 591 & 23 & 5 & 75 & 209.45 & 94.0 \\
\hline 591 & 23 & 6 & 75 & $\begin{array}{r}212.05 \\
21215\end{array}$ & $\begin{array}{r}93.4 \\
90.9\end{array}$ \\
\hline $\begin{array}{l}391 \\
591\end{array}$ & 24 & 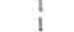 & 75 & $\begin{array}{l}2121215 \\
21285\end{array}$ & $\begin{array}{l}91.9 \\
940\end{array}$ \\
\hline 591 & 24 & $i$ & 75 & 214.35 & 93.4 \\
\hline 591 & 24 & 3 & 75 & 215.85 & 95.0 \\
\hline 591 & 24 & 4 & 75 & $\begin{array}{r}217.35 \\
218.95\end{array}$ & $\begin{array}{r}93.4 \\
0.45\end{array}$ \\
\hline 591 & 24 & $\begin{array}{l}3 \\
6\end{array}$ & 75 & $\begin{array}{l}128.89 \\
22035\end{array}$ & $\begin{array}{l}94,5 \\
94,5\end{array}$ \\
\hline 591 & 25 & i & 5 & 221.55 & 93.4 \\
\hline 591 & 25 & 1 & 75 & 222.25 & 94.0 \\
\hline 591 & 25 & 2 & 75 & 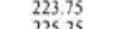 & $\begin{array}{r}94.5 \\
99.9\end{array}$ \\
\hline ६9, & $2{ }_{13}$ & 3 & 75 & $\begin{array}{r}225.25 \\
2267\end{array}$ & $\begin{array}{l}91.9 \\
92.4\end{array}$ \\
\hline 591 & 25 & 5 & 75 & 22825 & $\begin{array}{l}92.4 \\
945\end{array}$ \\
\hline 591 & 25 & 6 & 75 & 22976 & 940 \\
\hline 591 & 26 & & 5 & 23115 & \\
\hline 591 & 26 & & 75 & 23185 & 96.1 \\
\hline 591 & 26 & & 75 & 233.35 & 96.1 \\
\hline 591 & 26 & & 75 & 234.85 & 96.1 \\
\hline 591 & 26 & 4 & 75 & 236.35 & 98.2 \\
\hline 591 & 26 & & 75 & 237.85 & 96.6 \\
\hline 591 & 27 & 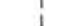 & 75 & $\begin{array}{l}240.75 \\
241.45\end{array}$ & $\begin{array}{l}96.1 \\
982 .\end{array}$ \\
\hline 591 & 27 & 2 & 75 & 242.95 & 96.6 \\
\hline 591 & 27 & 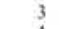 & 75 & 244.45 & 95.0 \\
\hline 591 & 27 & 4 & 75 & 245.95 & 95.5 \\
\hline
\end{tabular}


J. V. GARDNER, W. E. DEAN, L. BISAGNO, E. HEMPHILL

Appendix B. (Continued).

\begin{tabular}{|c|c|c|c|c|c|}
\hline Hole & Core & Section & $\begin{array}{c}\text { Interval } \\
(\mathrm{cm})\end{array}$ & $\begin{array}{l}\text { Sub-bottom } \\
\text { deph }(\mathrm{m})\end{array}$ & $\mathrm{WCaCO}_{3}$ \\
\hline 591 & 27 & 5 & 75 & 247.45 & $\begin{array}{l}95.5 \\
950\end{array}$ \\
\hline $\begin{array}{l}591 \\
59 !\end{array}$ & ${ }_{28}^{27}$ & 6 & 75 & $\begin{array}{l}248.95 \\
25030\end{array}$ & $\begin{array}{l}95.0 \\
97.1\end{array}$ \\
\hline & 28 & $i$ & 75 & & $\begin{array}{l}97.1 \\
94.5\end{array}$ \\
\hline 591 & 28 & 2 & 75 & 252.55 & $\begin{array}{l}94,5 \\
95.5\end{array}$ \\
\hline & 28 & 3 & 75 & 254.05 & 96.1 \\
\hline 591 & 28 & 4 & 75 & 255.55 & 99.2 \\
\hline 591 & 28 & 5 & 75 & & \\
\hline 591 & 28 & 6 & 75 & $\begin{array}{l}258.55 \\
56985\end{array}$ & \\
\hline & 29 & 1 & 35 & $\begin{array}{l}259.85 \\
25055\end{array}$ & 92.9 \\
\hline 591 & 29 & 2 & 75 & $\begin{array}{l}260.53 \\
262.05\end{array}$ & $\begin{array}{l}945 \\
929\end{array}$ \\
\hline 591 & 29 & 3 & 75 & 263.55 & 94.5 \\
\hline & 29 & 4 & 75 & 265.05 & 95.5 \\
\hline 591 & 29 & 5 & 75 & 266.55 & 94.0 \\
\hline 591 & 29 & 6 & 75 & 268.05 & 92.9 \\
\hline & 30 & 1 & $7_{-5}^{5}$ & 269.35 & $\begin{array}{l}94.0 \\
0.1\end{array}$ \\
\hline 591 & $\begin{array}{l}30 \\
30\end{array}$ & $\frac{1}{2}$ & $\begin{array}{l}75 \\
75 \\
75\end{array}$ & $\begin{array}{l}270.05 \\
271.5\end{array}$ & $\begin{array}{l}96.1 \\
940\end{array}$ \\
\hline 591 & 30 & 3 & 75 & 273.05 & $\begin{array}{l}94.0 \\
95.0\end{array}$ \\
\hline 591 & 31 & 1 & 75 & 275.05 & $\begin{array}{l}95.0 \\
95.0\end{array}$ \\
\hline 591 & 31 & 2 & 75 & 276.55 & \\
\hline 591 & 31 & 3 & & & $\begin{array}{l}70.6 \\
97.6\end{array}$ \\
\hline & 31 & 4 & 75 & 279.55 & 94.5 \\
\hline 59. & 31 & 5 & 75 & 281.05 & 95.0 \\
\hline & 31 & $\begin{array}{l}6 \\
3\end{array}$ & 75 & 282.55 & 95.5 \\
\hline 5918 & 2 & 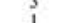 & 75 & 283.95 & 95.2 \\
\hline 598 & 3 & i & $7_{75}^{5}$ & $\begin{array}{r}289.85 \\
20095\end{array}$ & 93.7 \\
\hline $591 \mathrm{~B}$ & 3 & 2 & 75 & 29205 & $\begin{array}{l}92.7 \\
9.1 .\end{array}$ \\
\hline 5918 & 3 & 3 & 75 & 29355 & $\begin{array}{l}91.1 \\
93.2\end{array}$ \\
\hline 5918 & 3 & 4 & 75 & 295.05 & $\begin{array}{l}93.2 .2 \\
91.6\end{array}$ \\
\hline & 3 & 5 & 75 & 296.55 & 92.7 \\
\hline 5918 & 4 & 1 & $7_{75}^{5}$ & 299.45 & 90.1 \\
\hline 5918 & & & & 300.15 & 90.6 \\
\hline 5918 & 4 & 2 & 75 & 301.65 & 92.1 \\
\hline $591 \mathrm{~B}$ & 4 & 3 & 75 & 303.15 & 91.6 \\
\hline 5918 & 4 & 4 & 75 & 304.65 & 92.1 \\
\hline 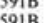 & 4 & ${ }_{1}^{5}$ & 75 & $\begin{array}{l}306.15 \\
308.85\end{array}$ & $\begin{array}{l}91.6 \\
906\end{array}$ \\
\hline $591 \mathrm{~B}$ & 5 & 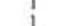 & 75 & $\begin{array}{r}508.85 \\
30955\end{array}$ & 90.6 \\
\hline $591 \mathrm{~B}$ & 5 & 2 & 75 & 311.05 & $\begin{array}{l}92.1 \\
92.1\end{array}$ \\
\hline 5918 & 5 & 3 & 75 & 312.55 & 91.6 \\
\hline & & 3 & 75 & 331.35 & 91.6 \\
\hline $\begin{array}{l}591 \mathrm{~B} \\
599 \mathrm{~B}\end{array}$ & ${ }_{9}^{8}$ & $\frac{1}{2}$ & 75 & $\begin{array}{l}337.95 \\
34905\end{array}$ & $\begin{array}{l}90.1 \\
906\end{array}$ \\
\hline S9IB & 11 & 1 & 75 & $\begin{array}{l}\begin{array}{l}349.05 \\
366.75\end{array} \\
3.05\end{array}$ & $\begin{array}{l}90.6 \\
91.1\end{array}$ \\
\hline S91B & 13 & 1 & 75 & 385.95 & 91.1 \\
\hline 5918 & 15 & 3 & 75 & 408.15 & 91.6 \\
\hline 5918 & & 3 & 75 & $\begin{array}{l}427.35 \\
436.95\end{array}$ & 91.1 \\
\hline $\begin{array}{l}5918 \\
508\end{array}$ & 18 & 3 & $\begin{array}{l}70 \\
75 \\
75\end{array}$ & $\begin{array}{r}436.90 \\
446.55\end{array}$ & 92.7 \\
\hline 5918 & 20 & 1 & 80 & $\begin{array}{l}446.35 \\
453.20\end{array}$ & $\begin{array}{l}91.6 \\
90.6\end{array}$ \\
\hline 5918 & 22 & 3 & 75 & 475.35 & 88.0 \\
\hline $\begin{array}{l}5918 \\
5918 \\
5\end{array}$ & ${ }_{24}^{23}$ & ${ }_{3}^{3}$ & $\begin{array}{l}85 \\
85\end{array}$ & $\begin{array}{l}485.05 \\
494.65\end{array}$ & $\begin{array}{l}90.1 \\
89.6\end{array}$ \\
\hline
\end{tabular}

